
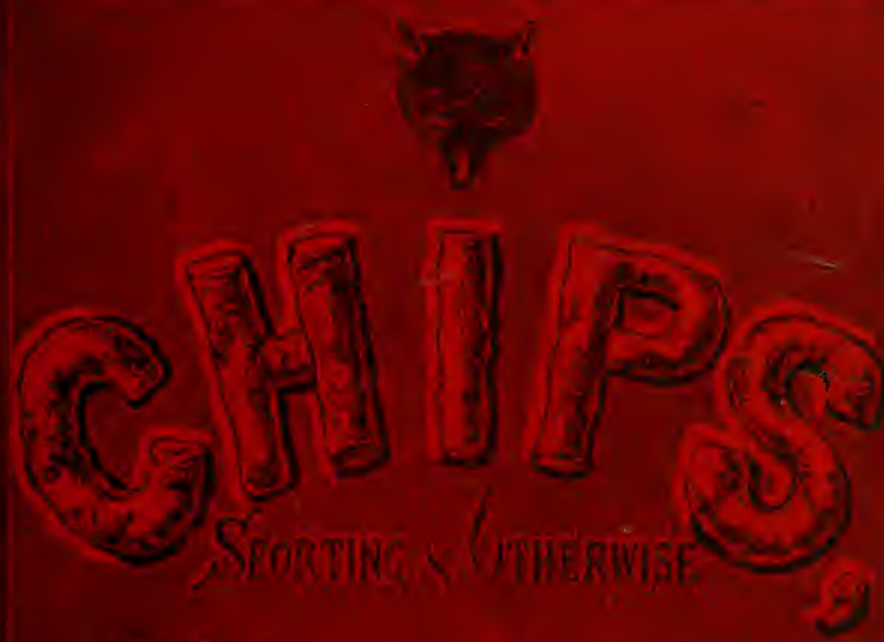

We

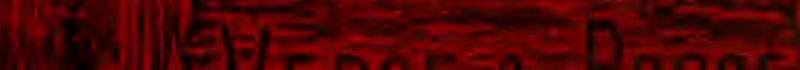
W. ERERT \& BOTSE

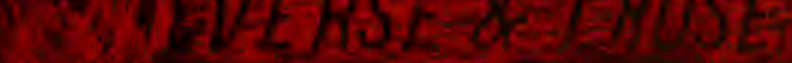

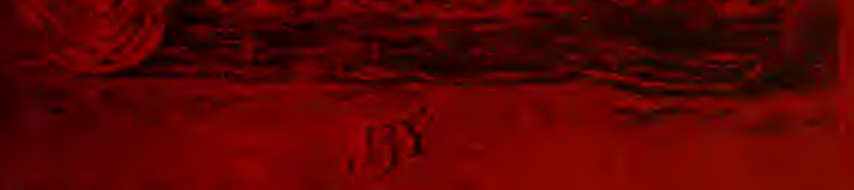

$$
\text { F. LS.W.WEDGE: }
$$




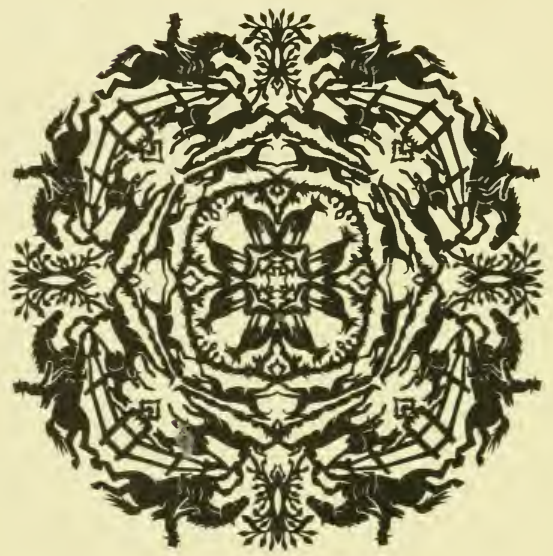

JOHN A.SEAVERNS 




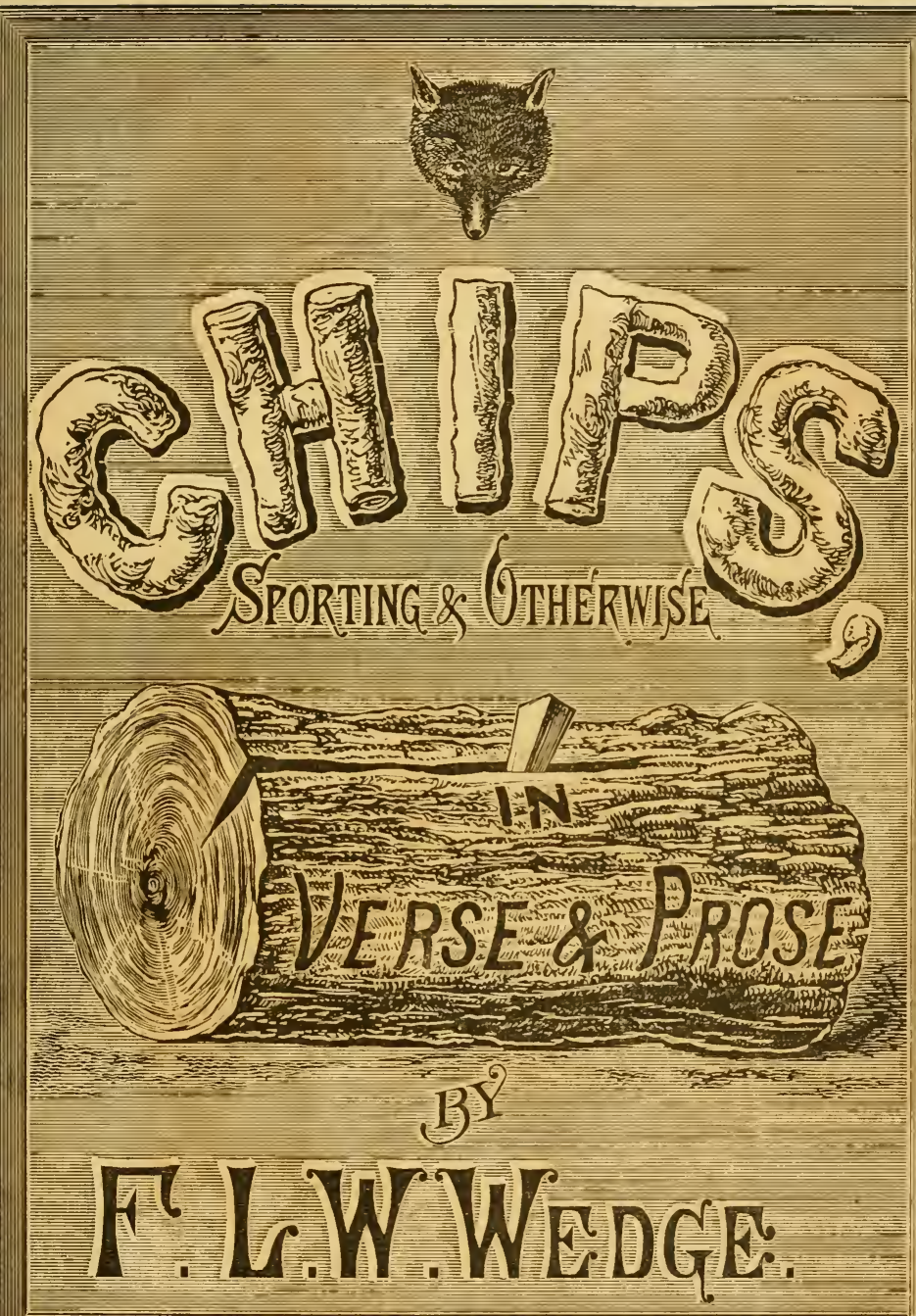

COVENTRY: W. W. CURTIS.

LONDON: HAMILTON, ADAMS \& Co. 



\title{
TO THE READERS
}

\author{
OF \\ "CH I PS."
}

\begin{abstract}
' 7 IS yours, this little varied pile
๖ 6 I scatter, and I trust

These Chips an idle hour may wile--

They've kept a Wedge from rust.
\end{abstract}

I hope they may not prove too dry, Chips should be crisp and light ; They're short enough, you can't deny, Though not, I fear, too bright.

The IVedge which knock'd them off, perhaps Work'd most on frosty days ;

And Leisure's beetle gave the raps Which chip'd off prose and lays.

Some fragments sprang from Mem'ry's tree, From Fancy's others flew ;

I' know not what their fate may be, But trust they'll please a few. 



\title{
I N D EX.
}

\author{
ERRATA.
}

Page 75, line 2, for "hunt" read "hint."

, 75, "2 23, for "hardiest" read "handiest."

" 90, " I 5, for " poundered " read "floundered."

" 94, " I 4, for " industrial " read " individual."

" $16 \mathbf{1}$, , 8, omit the word "now."

" I79, "I 5, omit the words "of so doing."

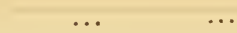

Men who Hunt, and their Peculiarities
A Bruiser ...
$\ldots \quad \ldots 64$

Old Bob

.

65

Cub Hunting

$\begin{array}{llllll}\ldots & \ldots & \ldots & \ldots & 74\end{array}$





\section{N D EX.}

PAGE.

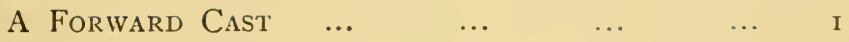

$\begin{array}{lllll}\text { The Farmer's CUP } & \ldots & \ldots & \ldots\end{array}$

$\begin{array}{llllllll}\text { Precious Moments } & \ldots & \ldots & \ldots & \ldots & \ldots & 8\end{array}$

$\begin{array}{lllllll}\text { TIT FOR TAT } & \ldots & \ldots & \ldots & \ldots & \text { I I }\end{array}$

$\begin{array}{llllllll}\text { JUMPERS } & \ldots & \ldots & \ldots & \ldots & \ldots & \ldots & \text { I } 7\end{array}$

$\begin{array}{llllll}\text { A GoOd Hunter } & \ldots & \ldots & \ldots & 18\end{array}$

The Dispersion of the Priors Curbeigh Flock ig

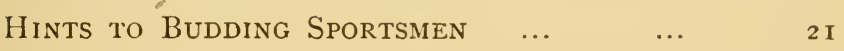

$\begin{array}{lllllll}\text { "GRANITE " } & \ldots & \ldots & \ldots & \ldots & 45\end{array}$

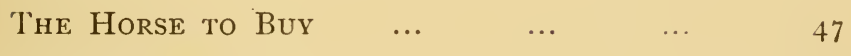

"CARPE Diem"

Men who Hunt, and their Peculiarities 54

$\begin{array}{llllllll}\text { A } \mathrm{B} \text { BrUISER } & \ldots & \ldots & \ldots & \ldots & \ldots & 64\end{array}$

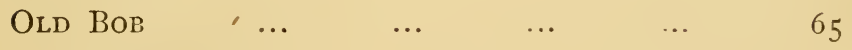

$\begin{array}{lllllll}\text { Cub Hunting } & \ldots & \ldots & \ldots & \ldots & 74\end{array}$ 
PAGE.

Two Copers 76

The Career of a Spur 86

DEPRESSION $\ldots \quad \ldots$

A Ducking

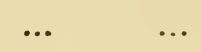

A FALL

A Crumpler

Some Exciting Moments

A Peculiar Being

Farmers and Fox Hunting

Oldo Care

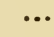

How they Courted

IMPATIENCE

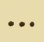

Those Inentists

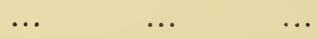

I 22

Riding To Hounds ...

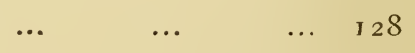

Twice Sold
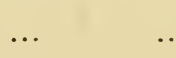

HiLLMORTON

$\ldots$

Walking a Puppy

$$
\ldots
$$$$
\text { ... } 106
$$$$
\text { I I I }
$$$$
\text { ... } 1 \text { I } 3
$$

I I 5

I 2 I

The Blist "Sport on EARTh

I 53

... $\mathrm{I} 60$

THE BIIST SPORT ON EARTH

On Selling Horses

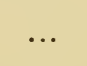


PAGE.

A Guod Run, and a Good Finish

I 72 RIIING aT FHNCLS-TIMBER .. 182

\begin{tabular}{|c|c|c|c|c|c|}
\hline$"$ & $"$ & IVATER & ... & & \\
\hline ", & " & BANKS, & Doubles, & Eic. & ... \\
\hline & ", & $\mathrm{AN} O \mathrm{XE}$ & $\mathrm{ER}$ & & \\
\hline
\end{tabular}

SUNSHINE AND SHADOW

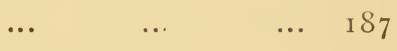

To E. M. W. $\begin{array}{llll}\ldots & \cdots & \ldots & \text { I } 88\end{array}$

FaC' asd Fiction .. $\cdots \quad \cdots \quad 189$

'I'is Well that WE ARE NOT 'Transparent... I 90 Patiently Strive to do Right $\quad \ldots \quad$... I9 A NEW YeAR'S IVISH $\quad \ldots \quad$... A Playful, love-lit Childhood $\quad \ldots \quad \ldots \quad \ldots 192$ Grey Hairs are Milestones $\quad \ldots \quad$... $\begin{array}{llllllll}\text { LOOKING } & \text { BACK } & \ldots & \ldots & \ldots & \ldots & 194\end{array}$ $\begin{array}{lllll}\text { A SPrig of ARBor VITÆ... } & \ldots & \ldots & 195\end{array}$ 



\section{$\ldots$ \\ Chips: \\ sparting (Btberiúse.}

\section{A FORWARD CAST.}

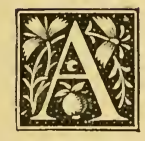

LITTLE more inaction, and again the joyous sound

Of heart-reviving holloa-of trusty note of hound-

Of cheery horn-of cracking briar-will drive our cares away,

As we rattle through the underwood the cubs at break of day.

And yet a little longer while-and glad November brings

With it the true commencement of the glorious "sport of kings;"

The sport I've longed and waited for since last I trotted back,

In the dust of scentless April, from the blooddeserving pack. 
'Though older I feel younger, as day by day glides by, And summer's blue departeth for winter's leaden sky; Wrinkles will quit my forehead, care to bliss yield up its place,

When again the woods re-echo with the music of the chase.

\section{THE FARMER'S CUP:}

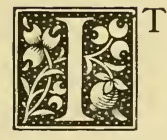

was market-day at Ridengton, and the bar-parlour at the "Golden Lion" was as inconveniently crowded as is customary upon that auspicious weekly occasion. Through the hazy, smoky atmosphere, in which it was enveloped, several largely-printed yellow-tinted programmes might have been discerned suspended from the walls, indicative of the coming 'chases; and in one corner of the room a little group of sportsmen might have been seen-as they would most certainly have been heard-discussing the said forthcoming events generally, and the Farmer's Cup in particular. An awkward, yet comely-looking "hobble dehoy" announced "As he wouldn't run 'is 'oss, lest he should lame him afore the Yeomanry training," whilst a stalwart farmer, of rubicund visage, and 


\section{Cyye Jfarmer's Cup.}

who could reckon some forty summers, declared, "As he'd like to ride as he was, but times weren't good enough for such as he to buy no racing togs!" Others said, "What's the use of running our horses against such as Bill Hicks, the dealer, and Harry Makesafe have got?" and with apparent reason, as for the last few years one or other of these celebrities (as arranged) had invariably pocketed the prizes offered at the local meetings for the Farmer's Competition, although their farms were to them, it is scarcely necessary to add, of very secondary consideration financially.

Whether it was owing to the strength of "mine Host's" whiskey, or otherwise, I will not venture to assert, but certain it is that an usually silent old gentleman, plentifully enveloped, as to the neck, in a blue bird's-eye choker, who had hitherto puffed steadily at his pipe almost unobserved, now vigorously thumped the table, and with a very expressive substitute for an actual oath, thus addressed the company present:

"Blarm me if I aint ashamed on yer all, after the old Squire has been and given you a Cup and Fifty Sovereigns to run for; and the entrance fee be next to nout." "There's new conditions," he continued, "and it aint no such certainty for they schemers as you mention. Blarmed if my old mare 
wouldn't as likely pass the post first as any of their galloping fal-de-lals!"

"Run her, then, Master Jenkins," was the prompt and tittering rejoinder to the above expression of feeling from more than one quarter; and, somewhat nettled by their ridicule, the fine old Yeoman's response came no less readily in the words, "I will!"-words which he had uttered with but little more solemnity regarding his better half, now some five-and-twenty years ago, and which he had always acted up to since.

Host Bull soon noted down Mr. Jenkins' black mare, "Otherdays," amongst the entries, and sundry little jokes as to the name being appropriate, and so forth, were pretty freely bandied about; and then, as the old cuckoo clock told its tale, the company one by one dispersed as the evening wore away. Respecting it, we need only further add that Mr. J.'s good lady upbraided him pretty freely upon his late return from market, and, we regret to say, called him "an old fool," when she heard of his having entered the mare; nay, worse, when he added with a slight hiccup that " he would ride her hisself," the good dame actually laughed outright, and with a not ill-natured shove literally bundled the spare old figure, who did duty for her lord and master, off . to bed. 


\section{The $\mathbb{A}$ Farmer's Cup.}

Now the said John Jenkins would not see his sixtieth birthday again, and was, moreover, a comparatively new resident in Clayshire, having until recently occupied a larger grazing farm in the Midlands from almost his boyhood, where he had gained in former years a reputation with the "Scentoview Hounds" second to none.

But times had been bad, and grey hairs had taken the place of black, so, upon his retirement to Clayshire, it is hardly to be wondered that scarcely a shadow of his former fame as a horseman had followed him. But he brought the old mare with him, notwithstanding (she whom he had ridden for nine seasons), if not the reputation which both had so deservedly earned in the earlier of them, for showing the way through many a brilliant run.

Time slipped away-as it has an unpleasant way of doing now-a-days-and when the day of the Hunt Steeplechases arrived, the names of only three runners appeared upon the c'rect cards for The Farmer's Cup,-the white feather, in the shape of half forfeit, having been displayed by as many more.

Thus might folks have read:

Mr. Hicks' b. g., "Shooting Star," by "Starlight,""Moonshine," 5 years. Pink, blue cap (Mr. Leatherem).

Mr. Makesafe's ch. g., "Express," by "Irish Mail,"- 
"Telephone," 4 years. Violet, white hoops (Mr. C. Makesafe).

Mr. Jenkins' blk. m., “Otherdays,” (Ped. unknown) aged. Blue, black cap (owner).

It was the first race of the day, and I shall never forget the chorus of vulgar laughter that went up from the ring as old Jenkins took his "preliminary" on his somewhat groggy old mare, alongside the two sleek thorough-breds, with whom he had elected to compete; yet the old fellow sat like a workman, notwithstanding, and if the mare didn't look quite racing form, she was all over a hunter.

"I hope the dear old man won't get hurt ;" "How silly of him to ride;" and such kindly-meant remarks, uttered by the fairer of the spectators were, however, soon unceremoniously drowned in the hoarse cry of "They're off," which, in turn, even temporarily silenced the constant yells of " 20 to I, bar a couple," and "Any price one of these runners," emitted from the unmusical throttles of the knights of the ring. How they did gallop away from him-those two well-trained blood ones-it really seemed "Lombard Street to a China Orange" against the old fellow, until the first six-foot ditch towards them was reached, where both the leaders, after sundry tries and refusals, had to await his pilotage, amidst much laughter and a good deal of cheering; then, being 
bent on the "pot," and not wishing further to expose their nags, they "waited on" the old man, who led them once more past the stand, and to within two fences from home, at a merely good hunting pace. It was a ridiculously slowly-run race, but, nevertheless, the finish was exciting enough as it transpired.

How well and gamely the old mare was jumping! but hulloa! What's up? round she whips at that last fence but one-her bad example being naturally followed, though in a less amenable degree, by the two shifty thorough-breds; but "old Jenks" is all there now, and has her round and over it in a jiffy, before even his opponents can get a pull at their raking and unruly steeds, and didn't the old fellow then put on the steam, and, having safely negotiated the last obstacle, set to to ride up the straight like a veritable Archer. Yet, although he was "finishing" all the way, he had not much in hand at last, for he only just got home half-a-head in front of the speedy son of "Starlight," who alone of the other competitors could be induced to bungle over the last two obstacles at all, and, when too late.

I fancy I can hear the ringing cheers which greeted the victor now.

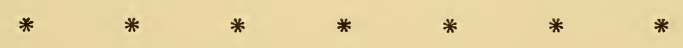

Mrs. Jenkins had a silk dress out of the stakes, in 
which she set the other farmers" dames "a-longing" for many a Sunday; and the massive silver cup still graces the old oak sideboard at the farm, whereif you call, as I did recently-Mr. J. will ask you to drink "Otherdays" out of it in some nut brown, home-brewed ale, and add, with a twinkle in his keen grey eyes, "She never refused but once."

\section{PRECIOUS MOMENTS.}

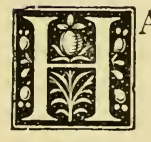

AVE you ever heard the patter of a wellbred hunter's feet,

With rapid strides the sodden turf, when well-extended, beat?

Have you felt the tug he gives you at his bridle to get on

To the other side those willows, where the dripping pack has gone?

Have you felt your pulse beat quicker, as those fifteen feet drew near :

Fifteen feet of running water, icy cold, not crystal clear?

Have you felt your muscles squeeze him as his sides you lightly press?

Have you seen his ears prick forward as the interval grows less? 


\section{羽recious fftoments.}

Have you felt the bound that follows-felt the rapid flight through air,

Heard the welcome "thud" on landing, with a little bit to spare?

Have you felt the effort over as you ease him in his stride,

That such moments can't be valued; that it's ecstacy to ride

Such a horse as this one, comrade? 'tis a joy none can surpass,

With a streaming pack before you, and beneath you green, green grass.

I have felt such priceless moments, live them now almost again,

Seem to feel my chair the saddle, and my pen the foam-fleck'd rein.

Would that life was fuller of them, for I rank a time like this

Second only (if it is so!) to a lovely woman's kiss ; And the consequences after, if your horse is sound next day,

Aren't disastrous, whilst the sequel to the latter who shall say?

Ride whilst nerve and pocket last you-Hunting is the sport of kings, 
King of sports I always deemed it-pleasure unalloyed it brings ;

Ride with pluck, but with discretion ; ride, remembering "your steed

Is the vessel-you the pilot to direct both course and speed."

Hounds the beacon are to steer by; eye, decision, hands and nerve,

Jointly use to keep them near you-such alone the end will serve ;

Then returning, the day over (P'raps at last reduced to ten,

Was the gaudy "field" which mustered fully twice one hundred men!)

If you were of those survivors when whoo-hoop the keen air rent,

Then returning home, be thankful, for your day has been well spent;

Joys like these are not so fleeting as some prosy people say;

Nerve and pocket both may fail us-health, alas! may too give way.

But whatever be the future-wheresoe'er our lots be cast,

Nothing has the power to rob us of the brightness of the past. 


\section{TIT FOR TAT:}

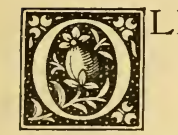

D Brigs had not climbed to the top of the tree in his profession without having learnt a good deal from the experiences he had gained whilst doing so, and if in his younger days he occasionally bought "dear," he assuredly in his latter ones did not sell cheap. He was one of the leading horse-dealers in Great Britain at the time I write of, and was not much less widely known across the Channel, where many a "third man" kept his eyes open on his behalf and for his commission. He was a clever old fellow, and could sum up a customer in as many seconds as it would have taken the latter years to fathom him. When a purse-proud snob came into his yard, he would weave into his conversation such a string of titled purchasers, and quote such figures, as would veritably have made even the shades of Burke and of Colenso shudder, and if he didn't plant him with a very indifferent horse at a very considerable cost later on it was a wonder, and assuredly not the fault of the dealer. If a retiring individual of less substance wanted an animal, having inentally booked his " outside" price at $£$ Ioo, Mr. Brigs would commence operations by showing him a really nice horse or 
two at double or treble that figure; and by this time the would-be purchaser would have usually so awakened to a sense of his own "littleness" as to literally jump at a slight whistler at three figures or so, which the owner would make him feel he was conferring a favour upon him by selling. The customers he liked least were those who knew what a horse was, and wanted their money's worth; for such usually bucketed his fat brutes about pretty considerably, and not unfrequently left without buying after all, because they could not get it.

Yet it was the fashion to buy from Brigs, and if sensible men kept away, and poor ones necessarily sought some cheaper market, yet there was still always a very handsome percentage of - well, the less ingenious, and a sufficiently fair sprinkling of those wealthy, to keep the great man's balance sheet at the bank very right indeed.

$\mathrm{O}$ ! the pedigrees which have been created in that snugly wainscotted parlour! In a few minutes-aye, seconds-the trimmed up progeny of an unambitious cart mare has there assumed an equine status which the Herald's College and unlimited $£$ s. d. have failed for several generations to secure to an aspiring human claimant. Old Brigs had always, too, a bottle of the brownest of brown Sherry upon the well-polished sideboard, and I do not hesitate to assert that it has 
not unfrequently shared the honours of "a deal" with the diminutive five-barred gate, or even the ostentatious, though roomy double without. He knew his business too well to risk even the semblance of a brook, though, in that seductive paddock!

He was quite the gentleman, was Mr. Brigs, and subscribed in such proportions to all the local charities and institutions as the lists of donors and donations were made public; and was he not respected by all, and written up by the Bladeford Express and Muddleton Chronicle accordingly!

The instances of his having sold horses well are naturally multitudinous, but I have only myself once heard of his being personally thoroughly outwitted, and it happened on this wise. Young Will Horseman, a farmer and fine rider, who had usually a horse or two to sell, and was always ready to buy, and capable of "making" a green one, was, one marketday, sauntering along under old Brigs' window at Muddleton, when his attention was attracted by the casement being pretty vigorously tapped from within by no other than the great dealer himself, who, having raised it and protruded his somewhat ruddy countenance, thus spoke:

"I've a nice young 'oss what 'ill suit you, young man; one as wants a bit of making, but 'ill pay for it. Come and have a look at him?" 
Will did, and the bargain was soon struck between them, for the horse was a good-looking one, and being old acquaintances and nearish neighbours, our friend, well satisfied and with no misgivings, took "the green one" away with him there and then in exchange for eighty golden guineas.

What a rank and unmanageable brute he was, however, he soon found out, although he never owned it to a soul until he had taken the revenge which I am about to relate.

Suffice it to say, respecting the horse, that he was very glad to get out of him three weeks later for an insignificant twenty sovereigns.

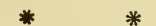

Months intervened, and again the heroes of my story met-old Brigs being no less delighted than astonished at Will Horseman's profuse thanks for the good turn he had so recently done him, and when the latter added, "Mr. Brigs, I sold that horse well (which was true), and should like to make you some suitable return," how greatly the older gentleman mentally pitied the purchaser of that diabolical chestnut can be more easily imagined than described.

Their conversation then turned upon other horses, and their meeting ended by Horseman transferring 
a slashing bay, on which he had ridden into town that day, to old Brigs' stables, in exchange for a scrap of paper representing $£ \mathrm{I} 7 \mathrm{o}$, at which the horse appeared cheap enough, after Will had larked him over every awkward fence on the great man's farm, and, in addition, "warranted him sound." Mr. Brigs chuckled when again alone, for a noble Marquis, who would give 300 guineas, wanted just such a I5-stone hunter, and to him he "wired" forthwith.

On the following day down came the said nobleman's Vet. by an early train to Muddleton, armed with a cheque for that amount, but lo and behold! when he reached Mr. Brigs' premises, and commenced examining the horse, the latter would not pass, being spun for two very decided and palpable side bones, on which, Mr. Leach remarked, he would assuredly go lame if put to work, and probably had already done so. Very irate at his own careless inspection of the horse, for there was no gainsaying their existence, and still more so at young Horseman's audacity, Mr. Brigs made it his business the following morning to drive over to that gentleman's residence-whither he had taken care to send the horse quietly on. Warm words on Brigs' part ensued on that occasion, but the younger man was cool, and as the Marquis's Vet. was unknown to him, the dealer very readily accepted Horseman's proposition 
"to take the 'oss back, and return the money if Mowbray would not pass him." The said Mr. Mowbray who, by the way, was the recognised head of the profession in these parts, was accordingly telegraphed to, requesting him to examine a bay gelding in dispute at Mr. Horseman's next day, and old Brigs drove back in his gig to Muddleton, thoroughly comforted in mind, and, he thought, secure in pocket also.

It was a nasty wet morning the following, and as soon as Mr. Mowbray arrived at the farm, the horse was briefly introduced to him as being " under dispute," Horseman adding, apparently to himself, but careful that his remark was audible enough, "and if you can make him make a noise, I'll eat him." It was a wet morning, I said, and one very unsuitable for dallying, particularly in the case of a professional man of such eminence as Mr. Mowbray, who had sundry other important engagements in divers directions to fulfil; so, after a cursory glance at the upstanding bay, in his well-bedded box, the latter was quickly saddled, and our crack Vet. soon in the pig skin, steering for the rick-yard gate, which, held open by our friend, admitted him to a fallow field of some magnitude, where he soon commenced bucketing along through the sloppy plough, as if finishing for the Derby. Never was a 



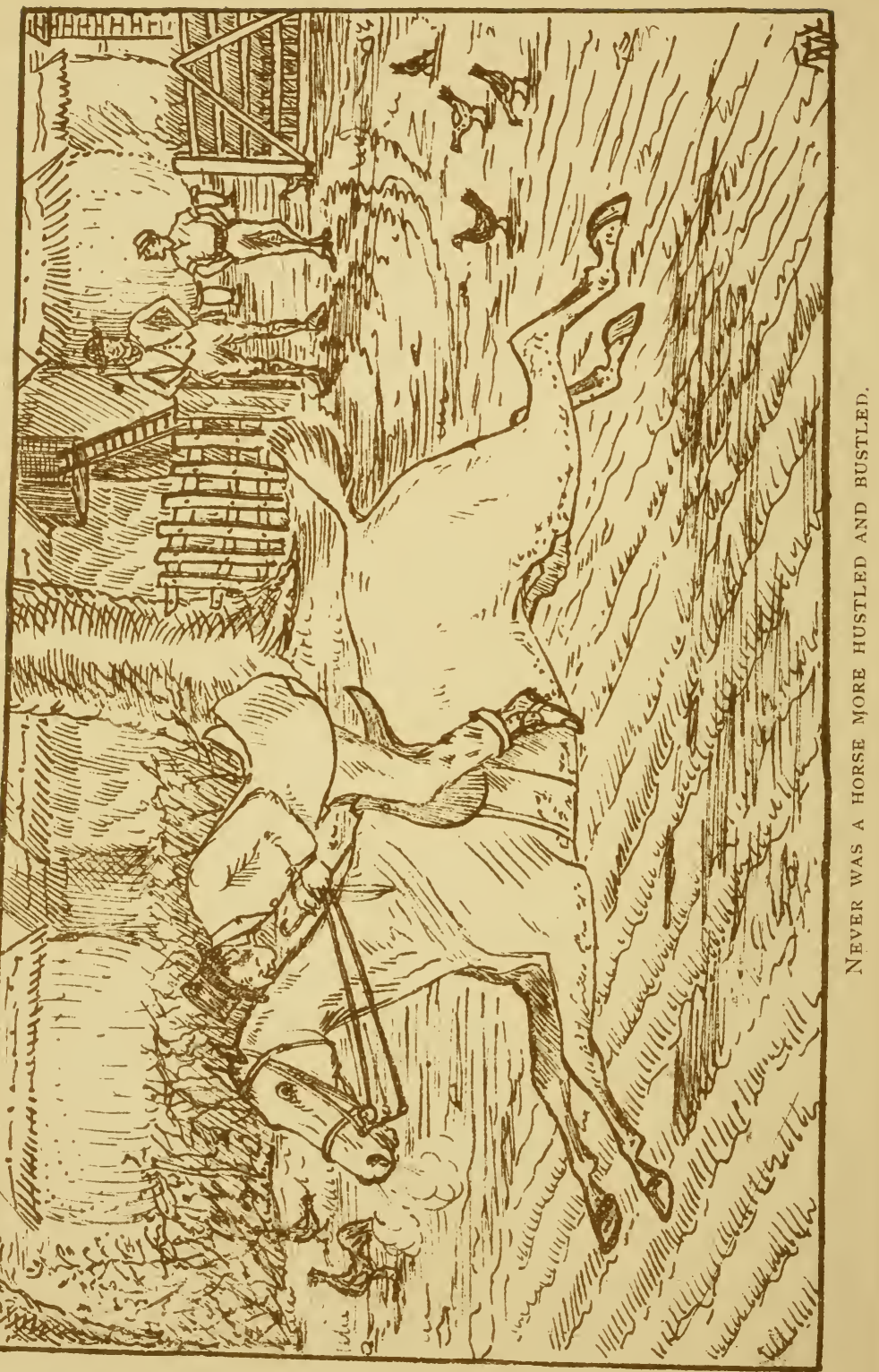


horse more hustled and bustled. Never was a horse mo:e abruptly pulled up, and never was a professional ear more attentively applied to nostril and wind-pipe! No go, however, for there was not the suspicion of a whistle, and his cough was as clear as a bell. So, after a disparaging remark on the capabilities of the Marquis's delegate, a glass of sherry and a biscuit, Mr. Mowbray certified, in his well-known scrawly characters, "that he had examined a bay gelding, etc. , etc., and believed him to be sound."

This scrap of paper and the horse were returned to old Brigs that afternoon, and if a coolness has sprung up since between Mr. Mowbray and young Horseman, and between Mr. Brigs and Mr. Mowbray, and, indeed, between Mr. Brigs and Mr. Horseman too, it does not very greatly concern us, as my story is at an end, and I hope you are as well satisfied with it as Will Horseman was with his revenge.

\section{JUMPERS.}

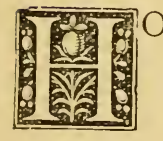

ORSES may jump well from various causes. Some undoubtedly do so naturally, more because they have been well schooled, and others because they have acquired, in determined, if rough hands, a knowledge of the consequences should 
they do otherwise; but I once remarked, whilst watching a point to point Steeplechase in the West of England, upon the extraordinarily big jumping of one of the participators therein, and the reason assigned by my companion was a novel, if not an altogether complimentary one. "That horse," he replied-mentioning him by name-"O yes, he is a terrific jumper ; but do you know why?" I acknowledged my ignorance of the cause, and he continued : "They say he's got fever in the feet so badly that he is only too glad to keep his weight off them for as long a period as possible!"

\section{A GOOD HUNTER.}

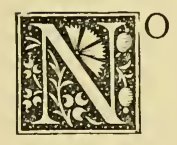

matter the color! no matter the breed! If he gallops and jumps well and stays; "A good horse a bad color cannot be" 's my creed,

And I heed not what anyone says.

The proof's in the riding-the way the horse goes, And the way he trots out the next morn; How's he bred! does it matter if nobody knows That his sire and his dam were e'en born? Not a whit, if he carries you straight in the van, And always can hold his place there; 
Can jump like a stag o'er what few others can, And, on landing, a leg has to spare. To such a good horse drink a bumper with me, I have one the cap fits in yon stall, On his back I don't care what the country may be, Or the pace, for he hardly can fall.

I know not his sire, and his dam I don't heed,

He is sound, and but six in the spring, He's e'er game to give, but ne'er wanting a lead, And's as fleet as a bird on the wing. May you own such another, there are some about, Though I own they're not thick on the ground; 'Tis a sort whilst the chase lasts should never die out, If a sort that is hard to be found.

\section{THE DISPERSION OF THE PRIORS CURBEIGH FLOCK.}

\section{PRIORS CURBEIGH VICARAGE,} TUESDAY, DEC. 3отн, I88-.

\section{EDIVIN WAYTE}

Is favored with Instructions from the Rev. J. G. Dickenson, who is leaving,

TO SELL BY AUCTION, AS ABOVE,

2 useful Ponies: Bay Pony, 7 years old, 13 hands; Mare Pony, I 2 hands; both quiet to ride and drive.

2 Dairy Cows ; Down-calving Cow ; Cow in full profit.

I Lamb. $6 \frac{1}{2}$ couples of Poultry. 


\section{Che 田íspersion of the 羽riors Curbeigh J Jlock.}

The following lines were suggested by an extract identical (names excepted) with the preceding, culled from the columns of a local paper.

19. $\begin{gathered}\text { longer the New Zealander will undersell } \\ \text { us now, }\end{gathered}$ For mutton here will shortly fall in price. There's a big Sale at Priors Curbeigh, and we'll show our cousins how

It is useless shipping here their sheep in ice.

Mr. Wayte has been instructed, and will mount the rostrum there,

And sell to the assembled crowd the stock :

Two ponies need no comment; nor the cows, a useful pair ;

But a very different matter is THE FLOck.

A leveller consignment I'll wager he's not seen, Than "the Lot" the reverend gentleman has here. And if buyers would secure e'en one, their biddings must be keen,

And I'm sure they will not buy a score too dear.

But the company looks puzzled, as it sees not ewes nor ram,

And in Mr. Wayte's eye lurks a playful smile, 
As he offers to the flockmasters of England ONE LAMB,

And conducts its sale in his accustomed style.

The buyers then turn homewards from the busy, bleating din,

But all feel convinced a better time is nigh :

For whilst Dickenson's are spared us fell disease can never thin

Our flocks as it has done in times gone by.

Here's a health in three times three to the parson, and may he

His new flock, lamb-like, find as that he's sold; Here's good luck to Mr. Wayte, and may it ne'er prove his fate

A less important "Shropshire" sale to hold.

\section{HINTS TO BUDDING SPORTSMEN.}

EFORE entering upon more important
matters connected with the hunting-field,
it will not be inopportune to devote a
few lines to the subject of Dress. For, although
various styles, from the resplendent war paint to the
less-assuming Mufti, are tolerated, it is not etiquette, 
nor would it indeed be expedient, in our variable climate, to take the saddle altogether undressed. Hats are worn in numerous shapes, and so changeable is the fashion in this respect, that a sportsman, who has been observed to ride throughout the earlier portion of the day in a highly-oiled and well-shaped "chimney-pot," has not unfrequently been known to smoke his homeward cigar under a head-dress bearing a closer resemblance to a partially-closed opera hat, or concertina, than aught else. I must add, however, that your hat-be it what it mayshould be secured by a string, or cord, of sufficient length to admit of the former, when dislodged, reaching at least as far as the loins of the quadruped you bestride. It is astounding to note the sharpening effects the continued pattings of a hat so arranged will have upon a nervous horse at his. fences, and often it will, moreover, enable the rider to take up a more prominent position in the field than he either anticipated, or, under other circumstances, would have been capable of acquiring.

Your coat may be of the orthodox scarlet, of black, or even of homely tweed, and its cut solely need depend upon your own individual taste, or that of your tailor. Extensively cut-away coats are, however, usually worn by-as they are indisputably the most becoming to-such sportsmen as may 


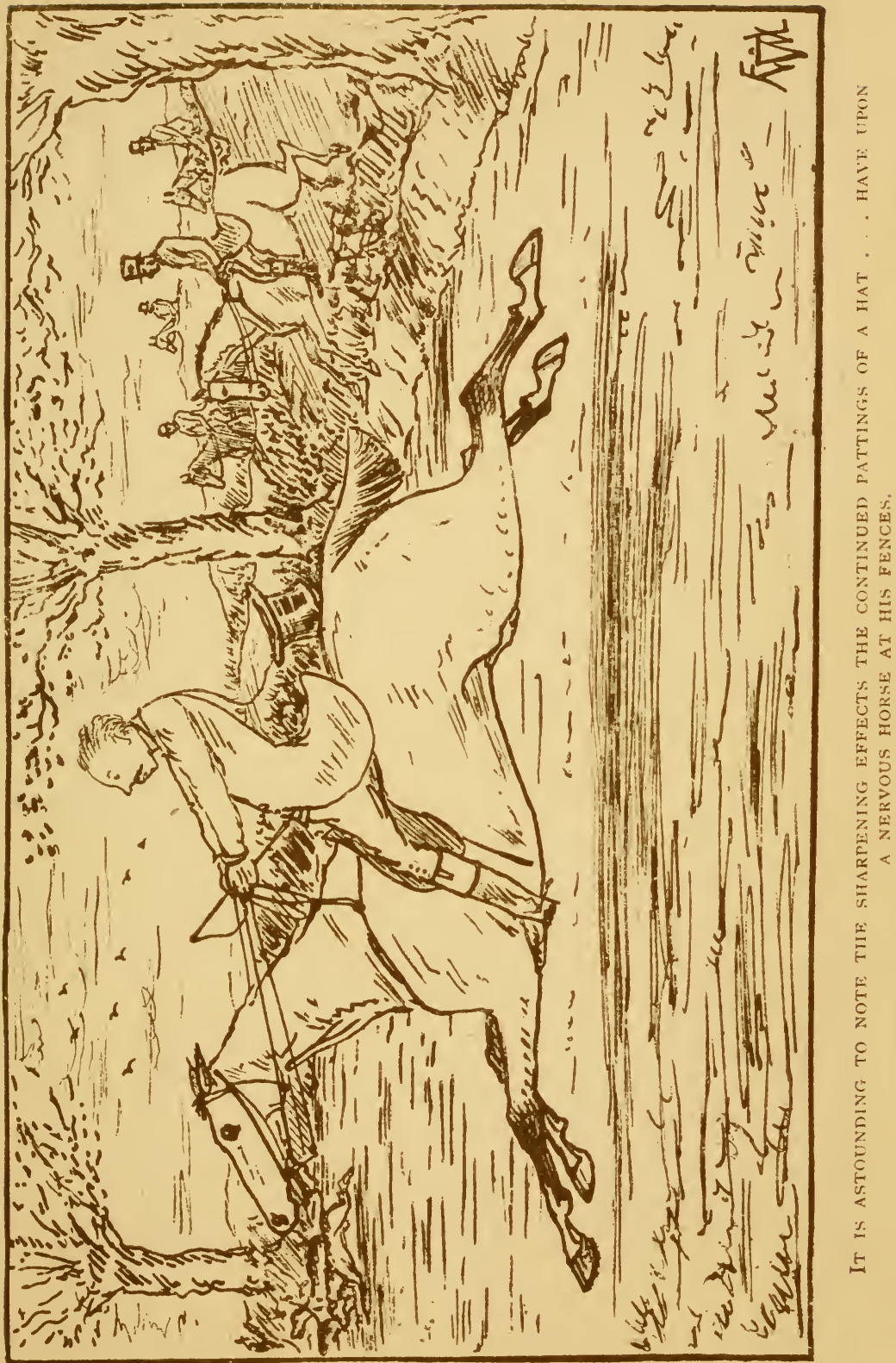



possess an undue preponderance of "second chest," for they are best calculated to set off the rotundity of the figure; and it is also a generally accepted rule amongst hunting men, that the more roomy the saddle required by the occupant so much proportionately shorter should the tails of his coat be.

We will presume that you are hunting in scarlet, and that the gilded buttons of your coat have your raised monogram artistically displayed upon them. The man who is happy enough to possess an $\mathrm{H}$ amongst his initials (though he may be incapable of using it in elocution), should, above all things, see that it is brought into due prominence, as, by doing so, he may possibly pass as an influential supporter of some distant pack.

Vests are immaterial as to color, but sportsmen of quiet tastes cannot perhaps select a neater pattern than horizontal bars of gold and black, at least four inches wide, and somewhat closely resembling the magnified carcase of a hornet. Breeches are cut in different ways, and worn in different fashions, and vary in material from the stylish buckskin, which, when cleaned, may assume a sky-blue hue, to the humbler Chipping Norton cloth. Some old-fashioned and particular persons display only, and always, four buttons on the outside of either leg, immediately between the top of the boot and the knee cap, and 
even go so far as to say that the slight indentation we all possess immediately below the latter was indisputably bequeathed us by Providence for the uppermost of these to rest in. But no rule in reality can be laid down as to this matter, for I have seen some equestrians with a row of shining, pearly buttons upon their plump thighs, well above the knee, and absolutely none below it; as others with only two or three buttons displayed above their boots, or even one only, as if on tiptoe, peeping timidly over the roomy top, by which it is well-nigh enveloped. Boots are of divers kinds; and "you pays your money," as the showman puts it, "and takes your choice." There is the stiff, upstanding, varnished boot, with its narrow salmon or lemon-tinted top, so stiff in appearance that it would, to the uninitiated, seem veritably to be made of japanned iron; and there is the equally unyielding "butcher" boot, corresponding with the above, minus the top; the wellboned ditto; and again, that so varnished, as to recall forcibly to one's memory the well-tarred sides of a disused canal boat. Then there is the solemnlooking, deep-topped boot, with legs possessed of as many or more folds than a Chinese lantern, the top of which veritably nearly rests upon the drooping spur. Again, you can, if you will, don the "Newmarket," with its drab and workmanlike uppers, or make your 


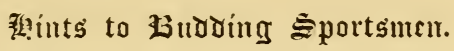

selection from other kinds and shapes, too numerous to mention. Suffice it, therefore, for me to hint to the novice that white tops go well with brown cord breeches, and that the exposure of two inches of the calf of the leg, encased in coarse blue stocking, or what not, between breech and boot, is both neat and becoming; and also that his spurs should be so loosely buckled on as to shake freely up and down on the heels in accompaniment to the varying paces of his horse. Spurs are equally serviceable whether worn this or that way uppermost, and equally secure whether buckled on the out or inside of the foot; these are matters of taste, but the longer the neck of your spur is, so much, as a rule, is it the better for your bootmaker, and worse for the Accidental Insurance Company you honour by your patronage, unless you put them on after you come down stairs; or, better still, have them adjusted by your groom when you are yourself safely located in the saddle.

Whips of various kinds may be, and are, used in the chase, and the selection of this or that pattern your own fancy may dictate, but the "correct carriage" of this article by the aspiring horseman cannot be too carefully studied. The "Fishing Rod" and "Fiddlestick" modes are perhaps at the present time most popular, and the art of posing yours as either may easily be acquired by watching the juvenile 
disciples of Walton upon any river or canal bank, or the performer upon a violoncello in an orchestra. If you have a thong to youriwhip, you will probably, at an early stage of your equestrian career, acquire the elegant knack of getting it beneath the cantle of your saddle when mounting-an act usually productive of graceful evolutions on the part of your steed, if not yourself, for some paces to followwhereas, if, on the other hand, you discard the lash, you will, in all human probability, drop your whip several times per diem, if not lose it altogether; which course, at all events, has the solitary advantage, if no other, of giving you sundry opportunities of mastering the knack of mounting well. In doing this you may either grasp the reins and stand (as our Cavalry do) with your back to your horse's head, or the reverse. If you adopt the former course, and your horse is restively inclined, you are liable to find yourself very shortly on your back instead of his; and if the latter, will not unfrequently be cowkicked, or (should you escape that calamity) deposit yourself, after a scramble, beyond the saddle upon terra firma.

It will, moreover, you will find, greatly add to your horse's lightheartedness if you allow him to feel the rowels of your spur across his quarters as you swing yourself into (or over) the pigskin. Sportsmen dis- 
mount with less ceremony-sometimes as they please, and often as they don't; now on this side, now on that ; often over their horses' heads, and occasionally in a Spurgeon-like manner over their tails. If you, however, ride in long-necked spurs, and your horse has the not unusual habit of tossing his head gracefully up and down after you have slackened or released your hold upon the bit, you will find no readier mode of dismounting than by throwing your right leg over his withers. The chances are that your spur will then come in contact with his neck, or mane, and the celerity with which you will dismount, should he raise his head favourably at the time, will probably astound you.

We will now suppose you to be seated in the saddle, with the reins, in a confused bunch, tightly grasped in your hand; and, further, that you have set your horse in motion in the most approved manner, which I need hardly tell you is by making sundry clicking or parrot-like sounds with the tongue. Here I may, by the way, note that it is desirable for you to put as much leather (such as noseband, breastplate, etc.) on your horse as he can carry, and regardless of his requirements. By such a course you keep the pores of his skin constantly open in the parts they chafe, and the custom is one favorable to the interests of trade. 
Covert coats, and overcoats generally, are of various shapes and patterns, and are usually conducive to pleasant and frequent visits from your doctor, who, if an agreeable fellow (as I have no doubt), will thus, if you don such, from time to time relieve the monotony of your home circle. To ensure this, after a cold storm fold up your coat and attach it to your saddle. You will probably then be in a profuse state of perspiration after the exercise you have been taking, and by the adoption of this course will, I will guarantee, rapidly become quite cool, particularly should the wind be boisterous and in the N.E.

Rick-sheet-like arrangements have also been provided by enterprising firms for your knees, and they may, too, advantageously be worn in showery weather. The folding up of these-when the rain ceases - is one of the most pleasing incidents of the hunting field, and will afford you considerable entertainment, as will, too, their attachment to your saddle should your horse be eager to o'ertake the now-advancing cavalcade. Mem.: In this case you will save time by stuffing them, as best'you can, into your coat pockets-it will, perhaps, prevent your losing a good start in a run, and certainly keep your sandwiches both cool and moist.

Mr. Jorrocks has told us all the uses of Berlin gloves, let me only add, therefore, that you will find 
leather ones best in cold, wet weather; the reins slip through your fingers more readily.

We will now accompany you to the Meet, and I need only say, "en passant," that it is customary (if you hack to covert) to ride all the way upon the centre of the footpath, and drive all females and others into the horse road, which, if not sufficiently good travelling for your steed, is always sufficiently wide for their accommodation. Your departure from home should be so timed as to bring you first upon the scene of action-you will then, for a while, at all events, be the admired of all beholders. If, on the arrival of the hounds, your horse should display any symptoms of freshness, keep his head well from them, and if he should happen to kick one, ride at once into their midst to express your sorrow, recollecting that every hunter should get accustomed to hounds, and that it is just as well for your playful quadruped to kill or maim all he is destined to the first day you take him out, as to injure or dispose of a similar number at longer intervals. On looking through the published Lists of Hounds in the Field, and other Journals devoted to sport, you will perceive that there is a plentiful supply in our islands, and, consequently, you may consider your misadventure as but of little moment, and the probable indignation of the huntsman and master as to some extent assumed. 
You have interchanged greetings with your acquaintance, and the hounds are now trotted off towards the covert they are destined to draw. As soon as they are thrown into it, post yourself at that spot at which, in your opinion, the fox is most likely to break, and which the remainder of the field have abstained from approaching. Should your judgment prove correct, and he-the fox which hounds are now running-attempt to break covert near you, at once holloa "Tally ho" in his face. By so doing you will show that you know a fox from a hare, and, what is of more importance, probably postpone indefinitely the more risky part of his pursuit, that is, in the open.

The fox has, however, we will surmise, broken covert at length in some different direction, and that you yourself have got well away with the glad throng in his wake. I may here add in parenthesis, that should hounds, through your own negligence, or from whatsoever other cause, get clear away from covert without you, that it is usual to swear the huntsman never blew his horn, and you may, at the same time, threaten to withdraw your subscription, provided you have been reckless enough to have ever given one. Recollect also, that if this plea is over-ruled, you can always assert, "no matter the pace, or the distance," that hounds "never really ran a yard." Fences, alas! must now occasionally be encountered; 


\section{Fints to 3suroing झportsnrer.}

and here let me impress upon the beginner the desirability of his, upon occasion, not being too proud to avail himself of the maturer judgment of some older Votary of Diana. For instance, should a sportsman have selected the weakest place in a strong fence, do not hesitate to avail yourself of his good sense, and charge it if possible before him, or, at all events, immediately alongside, or behind him.

Let not his falling, or a straggling hound, impede your course ; gentlemen are not very frequently killed in this manner, and hounds are, as before stated, sufficiently numerous in our different kennels.

Should you and the veteran sportsman, whose eye for country you have taken advantage of, both, however, fall, which is not improbable, and no serious damage be done to either, accuse him promptly of "foul riding," and get in a violent passion; or, if you have reason to deem it more discreet, apologise, and say you couldn't hold your horse. On other occasions, when you get a fall during a run, and are not hurt, invariably make the most of it-lie as if stunned for a second or two, and then get up, and writhe a little; it will probably ensure your horse (which you will, of course, have loosed) being brought back to you, which might not otherwise have proved the case, and so save you a lot of trouble. Further, if you re-mount, and continue to ride through the 
remainder of the run, will not people believe you to be a desperate plucky fellow! Never, however, assist another man when down, and on no account catch a loose horse yourself. If one approaches you, shout out to others to do so: it sounds good-natured, and won't delay you personally.

If a man has dismounted to unhinge a gate, or what not, press through before he has re-mountedyou would have lost time had you waited-and if he cannot get on again unassisted, the sooner he learns to do so the better.

It may here be as well to lay down a few simple and general rules to be observed when riding at fences, and the following may be found of use to the novice.

At a blind fence, or very strong high timber, you may find it conducive to your safety to spur all you know, give plenty of rein, and, if you have time and presence of mind, to administer also three rib-roasters to your steed as he nears the obstacle. This course gives him plenty of time to use the reasoning powers nature has endowed him with, as well as to collect his quarters well beneath him for the required spring, and many daily safely negotiate such obstacles upon this plan, although a fall cannot by so doing always be averted. At an open brook, ride as hard as you can until you get within fifteen or twenty feet of its brink, then seize the back of the saddle with your 



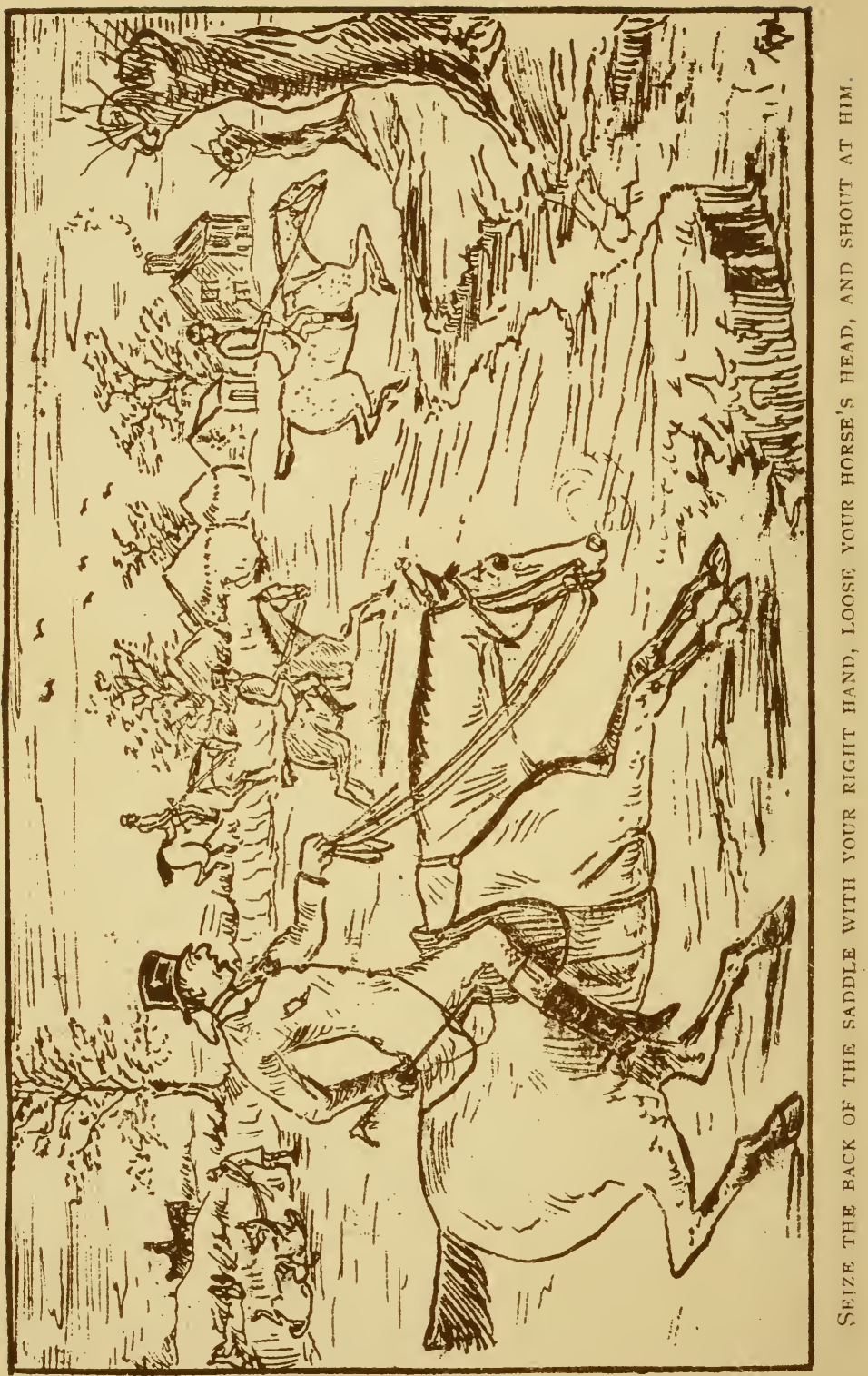




\section{Fints to Bubding Eportsinen.}

right hand, loose your horse's head, and shout at him. This course gives him confidence, and is very general. Awkward hairy doubles and bullfinches are fences to be shunned; but if you should find such unavoidably thrown in your way, and prefer the risk of encountering them to casting a shoe, or breaking a stirrup leather, I can advise no safer mode of doing so than this: Hold on by your spurs, shake your reins vigorously, and, above all, shut your eyes. On re-opening them you may find yourself safe and sound upon the other and desired side-thousands have, by acting similarly, done so before you. Never await your turn at a gap, but always "cut in ;" on no account giving place to anyone, not even in the case of a lady, or a lad; but, by crying out "Lady, lady," in remonstrative tones, you may, and often will, gain an opportunity of yourself slipping through the opening more quickly than you otherwise might have done, and the plan is, at all events, worth trying. Never assist the whippers in, or yourself prevent cattle or sheep from crossing the line of the fox, or from straying through an open gate on to public roads, or bye-ways. You come out to see hounds lumnt, and although the time it would take you to check the straying stock by closing the gate is unworthy of notice, whereas the farmer may later on spend anxious hours in collecting them again, recollect 
that that is his look out, and obviously no concern of yours. Therefore, should they get in front of your horse in a lane, gallop after them until they either succumb from exhaustion, or the course the fox has taken causes you personally to diverge to right or left.

Late in the season lambing has frequently been much forwarded by this system, although it has not invariably, I am told, proved of great benefit to the ewes. But you need bother your head about none of these matters; in the spring, or summer, when any claims or complaints which farmers have to make will probably be made, you will, doubtless, either be abroad, or at your London Club, and the long-suffering local subscribers will doubtless smooth all such matters over before another November comes round.

If you see sheep penned in brakes on turnips, mustard, or what not, always lark in and out over the hurdles. It may disturb the sheep somewhat, or possibly you may break the hurdles, and let them out; but the performance is not a risky one to you, and, consequently, such leaps may be indulged in with impunity. If the shepherd, who may be handy, should not applaud your horsemanship, be not surprised, they are an ignorant and unappreciable race, I fear, so far as such exploits of daring are concerned. When opportunity offers slang everybody who is 


\section{Faints to Zuraring Eportsincm.}

bestriding a young, green, or ungroomed horse, recollecting that hunters are heaven-born, and that it is quite unnecessary for the colt to serve any apprenticeship in other hands before he reaches that state of excellence which is adapted to your individual style of horsemanship and supply of nerve.

Invariably criticise and abuse the actions of the hunt servants when practicable, and as good scenting days and really first-rate runs are the exception rather than the rule, and a fox is by no means so easy a thing to hunt as a strongly aniseeded drag, you will have many opportunities of condemning Dick, Tom, or Harry during a season. After the huntsman has recovered the line of his fox, to the left, for instance, after a futile cast to the right, it will be apparent to a sportsinan of your observation that he was a fool not to have cast to the left first, and vice versâ.

The deeper the ground is, ride your horse the harder, for it stands to reason that he must require more coercion to get through it.

Discard furrows, in which your horse might possibly cross his legs, and ride for choice diagonally across all seamy, heavy ploughs. It will be unnecessary to point out that the faster you push your horse through them the sooner you will reach the sounder going beyond, and every good hunter should be able to go well through dirt. 
If you should be handy when hounds check invariably ride into their midst, or even beyond them. Later comers upon the scene will then remark the prominence of your position.

Should, however, the master or huntsman rebuke you, look upon their observations as purely formal, or as the promptings of envious and jealous dispositions. The fox will, at all events, appreciate the action you have taken, and, if the run has been fast till now, probably many of the horses also.

Be careful to pursue the huntsman when "casting," and under such circumstances laugh and chat in a loud key with your friends upon the topics of the day. By adopting this method you will assist hounds and huntsman more or less.

If a gate opens towards you, bring the off side of your horse against it with his head towards its hinges, and proceed to pull it against his shoulder, holding your crop in your right hand. It gives your horse time to regain his wind, as well as those of others you are detaining.

We have before mentioned spurs, the principal object of which is to hold on by. Recollect, however, that it is etiquette to term your horse slightly staked if you should have administered them too freely before the girths. If your horse is fresh, at all green, or self-willed, and refuses a fence, agree with 
him that its negotiation is needless, or undesirable, and ride off elsewhere, particularly if he should display a strong inclination to go thither, or show symptoms of rearing or kicking. If, on the other hand, you are on an accomplished hunter without vice, who is simply fatigued, and always providing the fence is small, then use the strongest language at your command, hammer him with your crop, and make him jump or scramble through it, explaining to your friends afterwards, in a knowing kind of way, "that he takes a bit of riding, you know;" they will then, doubtless, put you down as a bruising, daring dos.

If a friend is riding well up to hounds in front of you, and you, being better acquainted with the country, are aware that his course will shortly be impeded by some insurmountable obstacle, such as a fordless river, or canal, do not warn him of the fact, but hurry to the nearest bridge yourself, and, if possible, assume the lead upon the other side. It is also well to occasionally intimidate a hard-riding friend, should his horse have "the legs" of your own in a quick thing, by shouting to him "Ware wire about here, old fellow!" he will then usually go a bit more gingerly at his fences, and you may be able thereby to improve your relative positions.

To establish a reputation in a strange country, 
should you happen to be well placed in a good thing, owing possibly to your horse having run away with you, or from some other equally unavoidable or accidental cause, it may be worth your while when unobserved to absolutely chuck away your hat. The local "special correspondent" will, if near enough, make a note of the manner in which "the gentleman without a hat went," and, subsequently, immortalise you; whereas, had your curly pate remained covered, you might have passed unnoticed, and your doughty deeds have remained unsung. A new hunting hat will cost you a guinea more or less, so you must yourself judge when it is desirable to put this hint in force, as, too, when to withstrain your thirst for fame.

Never speak in a friendly, or even sociable manner, when out hunting, to any people who may not be within your own immediate circle of acquaintances. Farmers, whose ground you ride over, swear at, or ignore, as circumstances may suggest. Never buy a horse from one, however well you may see him go on it, but give readily $£$ Ioo more than he would have asked you for it when you recognise the same animal a week later in the stable of your own particular dealer. Vote all foot people a nuisance, and, when you can, ride them down in the open. A good opportunity to do this will occur when, as is of course your wont, you are pursuing a fox which 
has broken covert, regardless of the fact that not a hound is as yet upon his line. Always do this. It ensures you the best of starts, and a good beginning is, you know, a great deal. If, in fording a stream, you should find your horse suddenly shorten his steps, contract the muscles of his back, or commence scraping the bottom, or striking the water, at once loose his head. He will probably then lie down, and may arise much invigorated by his cold bath. You may personally get a wetting, too, but no good sportsman, like yourself, should dread that. The above advice is equally applicable in the case of deep and sludgy gateways. If you get a fall without your horse coming down, cut a voluntary, that is to say, on securing him smear his nose and forehead well with mud, when no one is looking; his appearance will thus be made more in accordance with that of your clay-plaistered self, and the subservient and unerring quadruped can tell no tales. The worse the scent is, the easier it is for you to distinguish yourself during the chase. Therefore, alvays on bad scenting days assume as forward a position as possible ; ride clean a-top of the hounds, in fact. By this means you will probably bring yourself to the notice of the master and the huntsman at as early a period of the day as by pursuing any other course. 
If you are asked by the master some such novel and original question as "Do you think you can catch him ?" (referring, I may add, to the fox), or are called in no minor key an adjectived tailor, accept such remarks as purely complimentary, even if to the ear of the novice they may savour slightly of coarse familiarity.

In olden times, and still, I believe, in some more obscure countries, (I) Fox, (2) Hounds, (3) Horsemen, used to be the order of precedence; but in the more fashionable hunts all that is now changed, although the fox may perhaps on occasion (that is, unless the hounds are being "lifted" at a hard gallop without one to the nearest likely covert) still be allowed his old place, hounds and horsemen are always, at all events during the earlier stages of a run, intermixed like the changing hues of a kaleidoscope, provided the scent is only moderate and the fences weak. If otherwise, the black, tan and white will, however, soon assume that position which is, by courtesy, still nominally allotted to it, and retain it, too, as even so hard riding a sportsman as you, my friend, must more than once have witnessed.

If a flock of merry school children are gleefully shouting at the termination of their lesson hours in the village hard by, when the hounds are moment- 
arily at fault; if a steam-engine utters a shrill shriek, or even one lad only is exercising his lungs for the laudable purpose of driving the crows from his master's field to that of his neighbour, say, "Hark, holloa!" it savours of keenness, and, at all events, shows that you are not at that instant totaliy absorbed in contemplating your own get up, or in thinking, with that satisfaction which is your wont, upon your own recently achieved exploits.

If after a good run you tell the huntsman or master that you think it was a fresh fox from so and so, or that hounds at all events changed later on at such and such a covert, it will go far to ingratiate you in their good books, although you may not find them alway's endorse your views.

When whoo hoop sounds at the end of a fine run, and you are lucky enough, if ever, to be amongst the few who are present to witness the last rites performed over poor reynard, you will remember to turn your horse's back to the wind, and tighten the girths as much as possible. $\mathrm{He}$ is thus less likely to get a cold in the head, and the saddle is made more secure for you to re-mount him. Having done so, trot him fast home, increasing the pace as you near your stables; you will thus bring him in in a comfortable glow. Should you find that he has a cough or cold settled upon him the following day, 
do not be surprised, horses, like ourselves, are liable to chills.

If you should hire a horse for a day's hunting, be sure and keep him out till the very last, irrespective of the nature of the sport and of his consequent powers of endurance. Recollect that your two-anda-half guineas cover all risks, and if you have had one clinking run, though long and trying, prog him also through the next, and if, by doing so, you should (as is probable) ride him to a standstill, leave him at some neighbouring inn, or farm, and telegraph to his owner to fetch him, deducting from your cheque, when you remit it, the amount you paid for the conveyance you yourself chartered in which to be driven home. You may be considered by some both humane and gentlemanly if you act thus, and will certainly have had your money's worth.

Never take any small change in your pockets when hunting, you can then say truthfully that you have none, should a rustic catch your horse, or render you some other service worthy of reward. Good nature, like virtue, should be its own reward, and very often is, I think.

Never personally give half-a-crown to the keeper in whose covert you so constantly find, it rests with your zealous and hardly-worked M. F. H. to settle these matters, as it does with Velveteen's master 
to pay him his wages; but, of course, if you were shooting with the latter for the supreme privilege of knocking over a few fat hand-reared pheasants, you would confer upon the keeper a golden tip. For the preservation of the foxes, however, which it is a temptation (if his master is at all lukewarm) for him to destroy, make him, I pray you, no acknowledgment. If gentlemen generally did so, even to the extent of a shilling or two now and again, I am convinced that it would set keepers very much against fox-hunting, and greatly diminish our prospects of sport.

It is, of course, unnecessary for a sportsman to subscribe to hounds, that is, if he is judicious enough to change his hunting quarters sufficiently frequently to avoid unenviable notoriety, but let him always be over-bearing in his manner to all holding a less exalted position than himself, or who are, at all events, worse dressed; and, above all, as before said, never let him consider or study the interests of that prosperous individual, the farmer. Fox-hunting may then possibly exist for the enjoyment of you yourself and such as you for many years to come.

Always take a week or ten days' change at Christmas, say to London; for, although you may by doing so lose a good run or two, you will undoubtedly save having to expend your money upon a multiplicity 
of tips, and, on your return, your neglect of having complied with this established custom may be overlooked by the hunt servants and others amidst the disbursements of the less ingenious, and you may thus indefinitely escape tendering any substantial acknowledgment to the men who have worked so hard and so successfully to show you sport, or what not.

Christmas, too, is a good season to migrate with your stud to pastures new. You will thus far have omitted to pay any subscription to hounds in the country in which you have up till now hunted, and in a new country the Secretary will not probably pay you any very pointed attentions for a month or two, and even then, should you succumb to his importunity, it will be an easy matter for you to get off with a very meagre donation, if you insinuatingly imply that it comes "dooced hard on a fellah subscribing to so many packs, you know."

You may also be quite sure, moreover, that if you do give absolutely or next to nothing towards the expenses of either pack, that the poverty-stricken landlords and other sporting residents in each hunt will not leave their M. F. H. in the lurch, and that they will as far as possible make up (no matter at what personal self-sacrifice, or inconvenience) such deficiencies as may have occurred, rather than that 
the old country should be less efficiently hunted, or a popular master resign. But the saving you will personally have effected, if put in the scale with their supplemented subscriptions, will go far to prove to a discerning sportsman like yourself, how far easier and less costly is the course you have so wisely elected to adopt. Scientia floreat.

\section{"GRANITE*"}

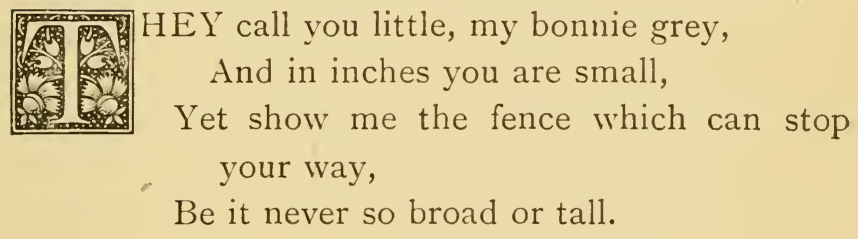

The "standard" says you're but I4.2, And it's all you are, but then Your legs are as short as I ever knew, And you've courage enough for ten.

Your firm strong neck, and your shoulders deep, And below, that swelling chest,

Those wide strong hips, and those well-arched ribs, And that heart which has fail'd no test. 
Your well-shap"d head, just a trifle long, And your "gaze," so frank and true, And that wise, wide brow, and that eye, no song And no words can do justice to.

The dappled skin, and the neat white mane, And jauntily carried tail,

A flag which has led men now and again To miscalculate brook and rail.

To go where that pony goes is not, They've found when the country's strong, So easy a task as they thought they'd got, And they needs must bustle along.

Comrades for years you've seen come and go, As my yearly sale came round; But for you there's a summer's run, you know, When the horn shall no longer sound.

You first I ride in September's leaf, And you last in April's dust ;

Few horses have shown me so little "grief," And in none have I put more trust.

Than you no better I e'er shall guide, And never expect the luck

During life's short span to again bestride So condensed a mass of fluck. 
You ne'er shall leave me, my little grey,

Though I've tempted been galore,

Those three fatal words "He is yours" to say,

When few needed the shiners more.

No! here is your home, my valued friend,

When old you shall rest at will

In yon shaded field, till your peaceful end

Shall proclaim a bold heart is still.

\section{THE HORSE TO BUY.}

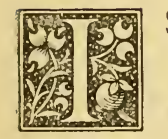

SUPPOSE most of us have some kind of ideal in our mind's eye of what a horse should be. I mean, such of us as are fond of that most useful of all animals, and are in the habit of buying them from time to time, even if few have the audacity to commit their individual ideas to paper. In doing so, in no arrogant spirit, myself, I will commence with the feet, and so proceed up his "understandings," as, should these prove unsatisfactory, we need not trouble ourselves with any further inspection of the horse with a view to purchasing him.

The feet should be open-round, without any 
tendency to flatness, or, worse still, contraction-of medium size, proportionate to the size and general symmetry of their owner, and, of course, sound. The coronets should be free from any suspicion of ring, or side bones, and the pasterns of moderate length; the fetlock joints flat (I abhor those small round joints, with which some horses are foaled), whilst the legs and sinews below the knees and hocks should be straight, clean, and, above all, free from sprains, however slight; if from splints, too, all the better, although these are seldom, when formed, of any real detriment to the owner if sufficiently forward not to press upon the sinews, and not situated so near a joint as to impede its free action, provided that from their position, and the horse's style of going, they are not liable to be struck in his paces. Knees and hocks should be large, the latter being free from thoroughpin, bog or bone shavin, and if from curbs also, so much the better. Curbs are, however, in my opinion, and so far as my experience has gone, seldom any real permanent detriment to a middle, or light weight hunter, and are more frequently developed by naturally bold free jumpers, when their powers have been taxed too early or too severely, than by other less gifted or generous animals. Old, or I should perhaps say seasoned, horses are hardly ever, I have found, lame with them, 
though the enlargement may be palpable enough. Capped hocks are only an eyesore, but avoid little weak hocks, however free from deformity. On the other hand, I would advise purchasers to be very shy of discarding a horse they otherwise like on account of the even suspicious coarseness of his hocks, provided he flexes them well in his paces.

Thighs, gaskins and arms should be large and muscular (but their development will, of course, depend much upon "condition"), and the measurements from hip to hock and elbow to knee should be as proportionately long as the canon bones should be short.

Hips I prefer ragged to narrow, and perhaps neither one nor the other to either; but a very narrow-hipped horse would have to show exceptional strength, both in the muscles below them and the loin, to engage my attention, and unless I knew from my own knowledge to the contrary, I should not readily believe such an one, without those redeeming points, to be capable of exercising the same jumping powers as his wider or ragged-hipped neighbour, even supposing the latter to be a trifle short in his back ribs to boot. It is immaterial how the tail is set on except for appearance, but a highcouraged horse more usually than not, in horsey parlance, "carries both ends well."

D 
I like what is called a jumping bump a-top of the loins, and the back cannot be well too short. What should make a horse a lengthy one are the measurements in front and in rear of it. Ribs should be well arched, but, except in a weight carrier, I do not so greatly object as some do to their being a trifle short at the back. Horses so made often gallop well, and have great liberty. The same may be said of moderately narrow-chested horses, who are generally pleasant in their paces, and easy to sit on, provided they are not "in at elbows" - a bad fault, and one usually attendant on brushing, if not speedy cutting. Shoulders in a hunter should be deep and long, and must be sloping, and the length in front of your saddle should be gained there, and not in the neck, which I prefer of only rnoderate length and straight to being much arched, although ewe necks are most objectionable of all. Although I can give no logical reason for being so, I am much predisposed in favour of a horse whose ears incline inwards at the points, and have seen them so carried by many game and good ones, whilst I cannot myself recall a single instance of a bad horse having this peculiarity. The jowl should be deep and forehead broad, the nostril large, and the eye-the greatest indicator of character and temperament-should, in addition to being large, also be bold and kindly in expression. 
In my own experience I have invariably found the best tempered horses make the best hunters, and I would not, at auction, myself buy a piggy, sour-eyed horse unless I knew something about his credentials. The character of a horse, like that of a human being, is as often as not discernible in his countenance, and if I set my heart upon a horse, his price suited me, and there was no palpable reason why he should not answer my requirements, I should not easily have my faith shaken in my choice were the V. S. not to pass him with a thoroughly clean certificate. Back your own fancy in buying as much as is consistent with ordinary common sense; and never buy a horse you don't personally like, let his credentials be never so good, is, I think, good general advice on which to act, and first impressions are not unfrequently the best, although they must, of course, be followed up by a subsequent and more critical examination. I have personally found the former to be generally right, and have often regretted having been persuaded not to follow them.

A horse should, of course, be sound in wind and eyesight; free from cribbing, and other stable vices; and stand straight and well upon his legs. Calf knees are ugly, but unless their development is very extreme, I think, except perhaps in a weight carrier, they are chiefly to be objected to on the score of 
appearance. There are many horses who, from foals, stand over slightly at the knee, and I do not dislike it, provided it is not the result of work; and although they are somewhat unsightly, I do not mind cycle hocks, and have often remarked that the possessors of them are great jumpers. Color is of little moment, although I should discard washy bays, or the lighter shades of chestnut, in preference to harder colors, and should not, unless about to start a circus, select a cream, or spotted animal, for my own stable. I have, however, seen some good roans and duns, although I should prefer my own stud principally to consist of bays, greys, browns, and blacks, with a liver-colored chestnut, perhaps, thrown in.

I prefer a plain horse, however, with character, to what may be styled a pretty one without it. No horse should "interfere" (that is, hit himself) in his paces; but, on the contrary, go clear and straight all round. If, however, a horse hits himself before, it is "your" look out, so to speak, and, if behind, "his own" only. The former, of course, being a habit which may endanger the rider's safety, whilst the latter will not. Many horses are pin-toed, or inclined to "dish," but their usefulness is not necessarily in the least impeded by such peculiarities of gait, although they are not to be desired. Don't 
buy a horse, however, that turns his toes out to any noticeable extent; such are almost sure to strike themselves when tired, or in deep ground, if they do not do so at other times.

Lastly, it is better to buy a good horse dear, if he suits you, than to purchase a bad or indifferent one for little money, for the latter cannot be cheap, and if the former will satisfactorily answer your requirements the first additional outlay will soon be repaid you-barring the accidents which all horse flesh is heir to-by the good services that he will render.

\section{"CARPE DIEM:"}

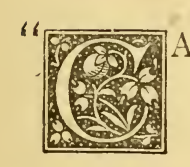

ARPE DIEM "-whilst we may

Let us love, or sport, or play ;

Let us, not forgetting others,

Grasp each pleasant hour, my brothers!

Night succeedeth day.

"Carpe Diem "-whilst we can,

In our short allotted span,

Let us taste the sweets around us,

Troubles may e'er long comfound us!

Brief's the life of man. 


\section{MEN WHO HUNT, AND THEIR PECULIARITIES.}

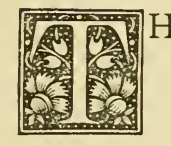

E majority of men who hunt may be readily divided into five distinct classes, which I will, under the following headings, endeavour briefly to describe: (I) Good men to hounds, (2) Hard riders, (3) Men who ride cunning, (4) Gap hunters, and fifthly and lastly, "McAdamisers."

By "Good men" I mean those only who come out to hunt, understand the science, are fond of it, and ride straight to hounds with nerve, decision, and judgment. Of such, I need merely say that, when encountered, they are readily distinguishable from the following peculiarities. They ride "to" hounds, not "at" or "over" them; are generally "there" at the end as well as the commencement of a run, and distress their horses far less than the majority of the field who, in comparison to them, see little or nothing of the sport.

"Hard riders" I must sub-divide as follows-for men who come out only to ride are of two kindsnamely, those who ride for pleasure, and those who ride for profit. The former, as a rule, although totally ignorant, and to a great extent careless, of the working of hounds, are anything but a displeasing 


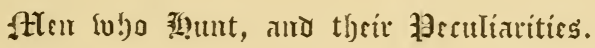

section of the hunting field, provided they are kept under proper control; for if they get a gallop, have some big places to jump, and are well carried, they are usually highly satisfied with themselves, their horses, and their surroundings. If, on the other hand, scent should be unpropitious, and hounds cannot run, they generally-to give them their due -bear their disappointments with quite as much resignation as others who do not lose anything in comparison to the exciting exploits they have been deprived of indulging in. They are also, for the most part, men who come out to be amused, and not to criticise either the performances of huntsman or hounds; and if others (particularly such whose opinions from the position they may occupy will carry weight) would similarly abstain from doing so without very good reason, many a young huntsman or promising whipper-in would gain heart as well as knowledge by experience, instead of probably losing the former (and possibly his place, too), owing to some hasty criticisms, thoughtlessly made, but eagerly repeated by the smaller fry of the "field," who proudly re-utter my lord Tom Noddy's unweighed sentences as the matured opinions of their august selves. And thus the ill-fated Tom or Charley is prematurely stamped as a failure, whereas the origin of the imputation of want of skill, or what not, might 


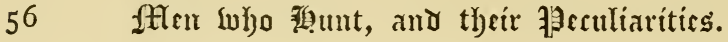

not unfrequently be traced to my lord's impaired digestive powers rather than to any real discrepancy on the part of the servant himself.

But the second division of this class brooks no delay, and it is, alas! not only a very far from harmless, but even a somewhat dangerous element in the field; for whereas, by that portion of hard riders whom I have already dealt with, the lives of hounds seldom and of individuals never are endangered, by the class I am about to introduce you to the lives and limbs of both are from time to time placed in very imminent peril.

Mr. A. is prominent among such, mounted on a raw brute which he hopes to make a long figure of by and bye, but which at present only promises to kick at everything and everybody within its reach. Beware of him at gateways, and give him, too, a wide berth at his fences, unless you are ambitious of being swerved across, charged broadside, or cannoned in mid air.

Mr. B. yonder, on that raking bay, which has evidently completed its education, and come out with honours, too, is another specimen of this class; but, mounted as he is, the hounds themselves rather than their followers are placed in jeopardy by his equestrian feats.

Mr. A. is, happily, usually invisible after the first 
ten minutes of a run, as by that time the raw, illconditioned brute he bestrides is probably quite ridden out, if not upon its back in some deep ditch; "in, through, or over" being the order of such an one's little day.

Not so, however, is it in Mr. B.'s case, whose horse is already ripe for sale, and whose performances have only to be seen to ensure its possession being coveted. This rider's sole ambition is, therefore, to thrust to the extreme front, and attract by some well-timed (?) leap the attention of the admiring (?) crowd.

Hounds being at fault on the far side of a tempting rasper will not deter him from negotiating it, if thereby he can display the brilliancy of his horse, even should the gallant bay alight absolutely in their midst.

$\mathrm{He}$ is establishing a reputation for his hunter as a free, bold jumper; and what, pray, as compared to that is the loss or disablement of an odd hound or two! Horse dealers, or their representatives, and some gentlemen who sell annually, may be found of this type, and none of the numerous sportsmen I am endeavouring to describe strike such terror into the breasts of both master and huntsman, or are half so cordially detested by each.

Let us turn our backs upon the unruly throng, and devote our attention to the more sportsmanlike, if 
less daring class, which I have styled Cunning riders. Amongst such may be often found a goodly sprinkling of genuine and thorough sportsmen, who, through advance of years, loss of nerve, or some other irremediable cause are unable longer to retain their old position in Class I. This is an eminently respectable portion of the field, and frequently also embraces men whose hearts are right, but whose purses are not, and who are consequently under-horsed, as well as the younger spirits who have not as yet aspired to higher honours.

The most noticeable peculiarity of its members is that they most invariably turn up, and appear upon the scene of action during a run when their advent would have been least looked for, or expected, which fact is attributable to their being generally piloted by some local "Bradshaw," who, if he does not (as I fear is sometimes the case) anticipate the point which the fox desires to make, and reach it before the latter, will certainly not arrive with his cavalry upon the scene long after him, and as often as not, except, of course, in a fast straight run, before his pursuers.

But we must again push on, or more correctly speaking, hark back, and leave this devoted company of "forward" sportsmen for the absolutely tag end of our scattered company-The Gap Hunters, or, as they might as appropriately be termed The 


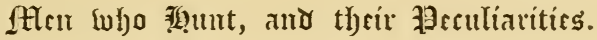

Agricultural Damage Department. These, as a rule, although lamentably and hopelessly in rear of all others, and to whom the sight and cry of hounds are literally unknown after the pack has broken covert, yet one and all religiously and systematically ride the line-'unting the 'oofs of the 'orses with as much assiduity as the hounds their fox. Now, provided that Mr. A., or some other enthusiastic spirit, has made a sufficiently weak place in each fence for their exit from every field in which no friendly "door" will serve their purpose, all goes well; but, should even an obstacle of the most moderate size present itself, a general halt ensues, and the most obliging spirit of the discreet band will dismount to pull out a rail, unhinge a gate, or destroy a mound, as circumstances may demand. During his labours for the common weal, he will be not unfrequently encouraged to extra exertion by his anxious comrades in this wise, "Pull out that stake now you are down;" "Get that other rail out, can't you?" "Nell done!" "That's better!" and so forth; but no sooner is the obstacle under demolition sufficiently reduced in size to admit of their safe egress, than further civility is cast to the winds, and they proceed en masse for the opening, crushing through it as best they may, and leaving the obliging party who enabled them to do so ankle deep in mud (if not knocked down), to 
re-mount (if his horse has not been let go) in meditative solitude. This distinguished company can generally boast of a horsebreaker, taking the change out of some grass-fed three-year-old entrusted to his care (?) - numerous fat men on ponies, and other indifferently mounted ones; but it is not without shame that I must also chronicle as being by no means unfrequently in their midst, sundry wellmounted and pink-coated duffers, who, having got a good start, have by funking and craning so completely resigned such position as they should have held, as to have been literally overtaken by our aforesaid friends. By the same, however, these exquisites are held in great reverence, and, between the obstacles, the command of the detachment is usually taken over by one or another of them. This prominent position, however, they will unselfishly resign as they near the headland furrow, and allow one of their less ostentatious followers to then assume the leadership, and subsequently demolish the fence to be crossed as may be required, and as has been described. Such swells as these are remarkable for hollaing at and jagging the mouths of their (for them) too ambitious steeds, for speaking impatiently, to say the least of it, to the kind-hearted one who is endeavouring, dismounted, to reduce a gap two feet high to negotiable dimensions, and so forth. 


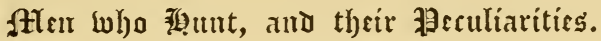

When that is accomplished, however, the keenness of such bucks knows no bounds, and a hasty "Let me come!" "Now, sir, are you going?" "Get out of the way with that pony!" or what not, is hurled contemptuously at such other ardent spirit as may have simultaneously hardened his heart to the same pitch.

The chief features of enjoyment in the days of this division of fox hunters are that they are invariably totally unconscious of the existence of checks! Thus, a run of twenty minutes to those with hounds may, to the best of their belief, have lasted an hour, forty-five, or thirty minutes, according to the time it took each individual member of the department under notice to reach the point where it terminated, if he should indeed ever have succeeded in doing so.

My subject is drawing to a close, and the "McAdamisers" alone now require consideration. These, unless fortune acts fickly indeed, and contrary to tradition, are usually, too, absentees from find to finish, but if they should happen by any happy nick to turn up during a run worthy of the name, it is more frequently than not in an undesirable place, and to the prejudice of other's sport. Their arrival (for they hunt together) upon the scene of action is usually, therefore, greeted with "Hold hard there!" "Don't override the line!" or somesuch exclamations of reproof or remonstrance, 
in which those not immediately in advance of the cavalcade join in tones of apparently the gravest distress or most profound entreaty.

Under this heading come the following: Muffs of the deepest dye, who come out because they think it is fashionable, or because their wives think so, and send them. Namby pamby young mashers, who think their hunting dress becoming, and hope by joining in the best of field sports to be looked upon as manly, if not valiant, by fashion's marriageable daughters, and who, if they stick occasionally at the fences when in the field, stick at very little, and certainly not at facts, when relating their adventures subsequently in the drawingroom. The queen of such an one's affection will probably address him somewhat after this manner"But hunting is so dreadfully dangerous, is it not, Mr. Muffit?" And Mr. Muffit's carelessly-uttered reply will perchance be built upon such lines as these: "Of course, there is some danger, you know-gives zest to the thing; but the worst falls usually happen to timid riders, and at small places. Men (the speaker is probably eighteen next spring) who ride really straight seldom come to much grief, I find;" and the fair listener's eyes will fill with a look of wondering admiration as she pictures to herself dear Augustus taking canals, rivers and locked gates in his stride, as young men in the sporting pictures she has seen 


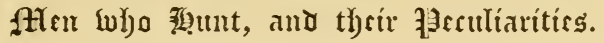

always appear to do with such ease whilst turning partially round in their saddles, and holding well aloft their whip hands.

To this throng also belong the liver brigade-such second horsemen as are not riding pretty hard in front or in rear of their respective masters, and the more humane if less ambitious of the badly mounted ones.

Before laying aside my pen, I may add that I honestly do not believe this sketch to be overdrawn, although, of course, you, and I myself, and every reader of it, are undoubtedly in our own opinion members of the first and most exemplary division of sportsmen.

Notwithstanding this, however, I should like to wager that ninety men out of every hundred who appear at a meet, would (if each individual man of them was started alone from a covert, with a pack in full cry and a burning scent) totally lose the hounds in less than half-a-mile, let the gentlemen concerned be never so well mounted, and the country only a moderately strong one. In all probability, indeed, the majority would lose their heads in the first field, and, having taken eyes off them, the hounds in the next, for, alas! how few of us there are who are dependent solely upon our individual abilities for the sport we see! 


\section{A BRUISER.}

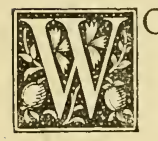

OULD'ST thou ken our local bruiser-see him ride, and see him fall,

See him rise again, and hustle to the fore to lead us all?

You must come out in our district, where he daily, without fear

Pounds along on any cattle-hounds resolving to be near.

Would'st thou see him really happy? then upon an awful brute,

When the multitude is pausing, watch him from the horsemen shoot;

See him pick the blindest portion, where the barrier's most high,

Note his dauntless resolution for a fall, if not a fly.

Don't be anxious for his safety-years ago we wonder'd, too,

How it was he never happen'd once "to die instead of do ;"

He has lost an eye, a leg broke, and has fractur'd too, his nose,

As, when you have seen him riding, you may readily suppose. 
Be it water broad, or timber, and he knows his horse won't rise,

Then his eye with rapture glistens as the Brummagem's he plies;

Many times have we been grateful for the hole his plucky lead

In a fence has made, and duffers thus impounded oft he's freed.

Oh! the mud which, in a season, that bold back has taken home,

Should the garden at his lodgings greatly have increas'd in loam ;

May he long be spar'd to show us what real pluck can dare and do,

For, if reckless as a horseman, he's a sportsman good and true.

\section{OLD BOB.}

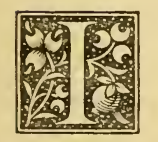

HADN'T seen him for some three or four years, and was so surprised at hearing again the voice with which I was then so familiar, that I literally stopped, for the nonce, chewing the very moderate sample of foreign oats which, with a goodly proportion of chaff, comprised the contents of my nose-bag. I was on the rank 
in Piccadilly, near the green park-that which faces Half Moon Street, I mean-and was resting my gammy leg, as I often do now (that is, as often as I can), when he strolled up.

"Cab," he holloa'd, and it was the same voice that had encouraged me to exert my utmost powers through many a trying gallop in the past. Off was jerked my nose-bag in a jiffy, and for the first time in my life I did not spring quite willingly into my collar to pick up a fare for good old Tom, my driver.

"Whoa, old man," said he, soothingly, as I lashed contemptuously back at the dashboard, when my former owner-for it was no other-placed his $I_{3}$ stone 7 on the step of my tidy hansom, and directed Tom to drive him to a certain West End Club. Now I never do make it a rule to kick back in the vulgar way some cab horses do, and I knew from Tom's voice and manner that he was shocked; but I was a little upset just then, and did not altogether like my "fare," who, I think, you will allow, when you have heard all, had not treated me quite straightforwardly. He did not recognise me. O, no! for I daresay I have changed.a good deal since we last met, or he might not have felt altogether surprised at my lack of common civility, for I must confess that I did just peep round as he alighted, and, by a well-timed jerk, cause as unsightly a dent in a well- 
brushed "Lincoln \& Bennett" as need be, as well as cause sundry very unparliamentary expressions to proceed from its discomforted wearer.

I fear also, alas! that I thereby deprived my worthy driver of anything over and above the actual fare laid down by Mogg, for he certainly jagged me in the mouth as we again got under weigh in a manner which was neither conducive to my comfort or his wont. I had several other short "runs" that afternoon; but my thoughts were in the past, and I did not, I know, work as cheerfully as usual. Indeed, I fear I must have thoroughly disgusted my coachman, good suul, for, on taking me back to our stables, he distinctly called me "an idle old warmint," and omitted to give me his accustomed pat on departurea caress which I look for and value a good deal now-a-days.

When the rough old stableman who looks after me and five others (what would his stud groom have said to that ?) had done us up that evening, I just thought seriously over my past history, and could come to no other conclusion than that I had been treated uncommon shabbily. I remember Mr. Thankless buying me as a four-year-old from young Greenfield. I had not then been over from Ireland more than three months, and was, although "I says it as oughtn't," about as smart a youngster as one could 
cast eyes on. Bob Greenfield bought me at Rugby Fair from Pat Murphy, and it was when he "set" the field on me with the Pytchley over a hog-backed stile into a lane, that I first came under my late master's notice; yet, although I know Greenfield only gave 60 for me, and had just a little back (for I heard the deal), I also know that I was, at the time I write of, a downright cheap horse at go guineas to the Squire, at which figure I was transferred to the Hall stables next day.

At first I think he was a bit afraid of me, for I was very keen to be in front then, but little by little he got to trust me, and that his confidence was not greatly misplaced I think you will admit when I unhesitatingly avow that I only gave him two falls during the five seasons I carried him. By Jove! what a clinker that was with the Cottesmore-there were only three of us got high and dry over the big brook that day, for sixteen feet of naked water takes some doing; and I might there and then have again changed hands for a couple of hundred, although I had not as yet been hunted throughout two seasons. His lordship offered that for me ; I forget his name, though he used to go well, too; but the guv'nor said (and how well I remember the words), "No; he is the best and gamest horse I ever owned, and I will never sell him, thank you all the same." 


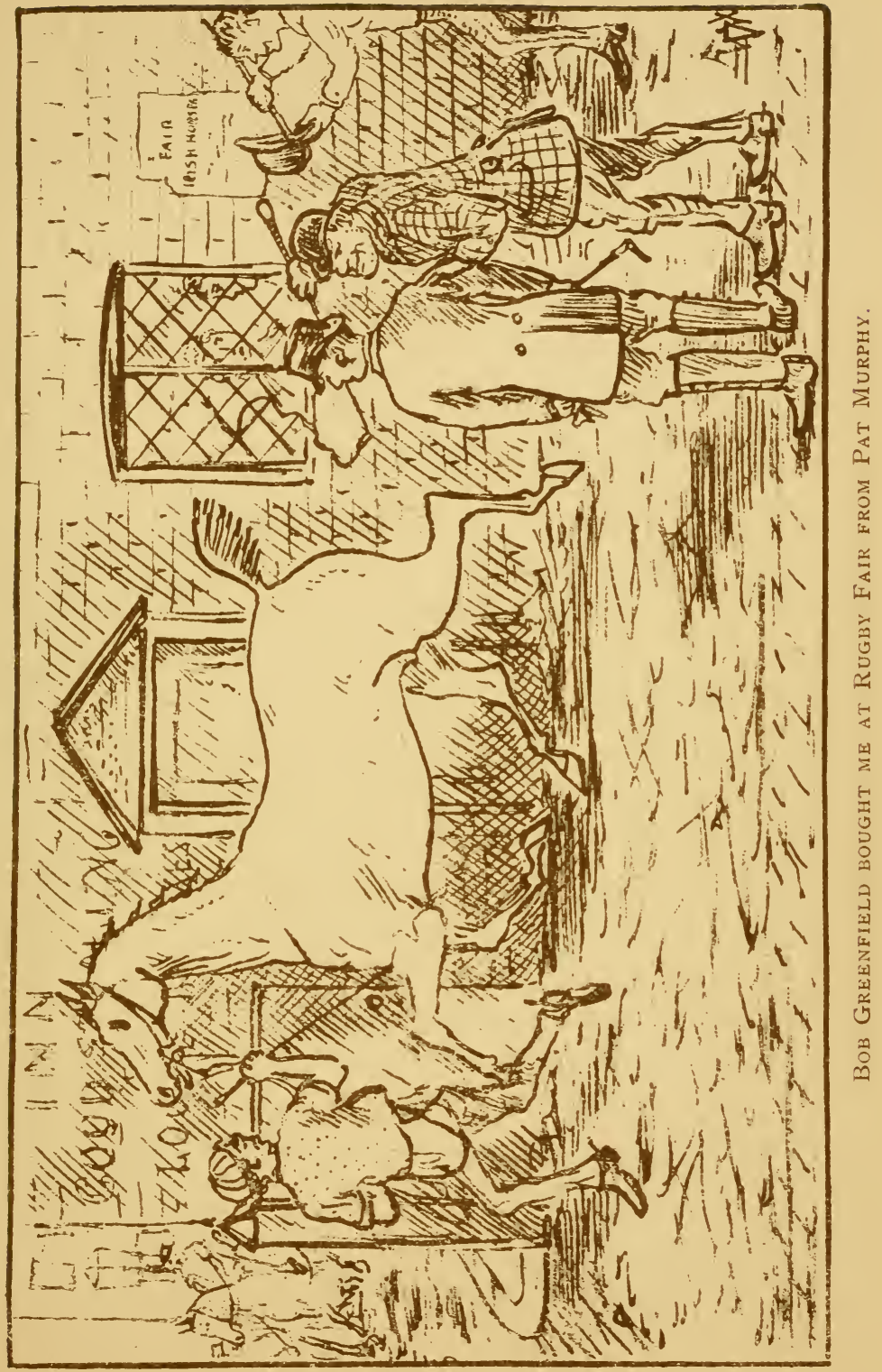



How proud I felt that day, to be sure! and erer afterwards I endeavoured, when opportunities arose, to, if possible, surpass my previous performances. Five seasons I carried him, and then, alas! on landing in a rabbit hole, this poor old sinew went. It was only the second fall I had given him, and I then thought he seemed very sorry for me, as, having bound his handkerchief round my leg, he led me limping home for some seven miles; but I have since learnt, alas! that he was only sorry for himself. How I stood for weeks with that poor leg generally in a pail of water, and how, by and bye, old Scorem, the Vet., came and fired me, I hardly care to recall; let me, too, pass over an interval of some months spent in a moist low-lying meadow, where my only associates were some cows and the most impertinent of donkeys.

At length, however, I was taken back into the stable, where, after a little conditioning-my corn never having been wholly stopped-I felt almost, if not quite, my former self. The young master was to ride me on account of his weight, and did; but what a shockingly bad rider he was to be sure!

Hands! why he said I pulled too much for him, whereas it was he who pulled, forsooth, not I. The fact, however, remains that we did not get on well together; so, in consequence, I was handed over 
temporarily to Mr. Driver, the breaker, and in a few days-for I never had a particle of vice-became a harness horse.

Transferred from the care of the stud groom to that of the coachman, I soon experienced how fleeting a thing is popularity, for, although the former occasionally came to give me a kind word, or even a carrot, for auld lang syne, I knew the latter never liked me, and I consequently had to do all the long single journeys and night work which he could give me. I did not step so high, I know, as "Firebrand," the only horse of my own color, and with whom I was, when in double harness, driven, but even he, showy as he was, could not deny that I, poor old "Goldmine," did, at all events, the larger share of the work.

Well, at length I fell lame-very lame; the smith had driven a nail a bit too close, that was all; but this opportunity was seized by Boxseat, our coachman, to persuade the Squire to draft me. Had he forgotten his promise, I wonder? or the glorious gallops we had enjoyed together when he gave his consent? I know not; but this I do know, that if he had I had not, and that I felt most heartily ashamed for him when I found myself a few weeks later on sent up to Messrs. Tattersalls' spacious premises at Albert Gate, as an odd lot, "to be sold." 


\section{Artr Liob.}

I was not thoroughly sound at the time, I will confess; but still almost hesitate to acknowledge that, although serviceably so, still good looking, and not eleven years of age, I only realized the paltry sum of 18 guineas! for which figure I was secured by a dealer, who, in a few days, transferred me at a small profit, together with another old hunter (with whom I often chat over times past), to the stable in which I am now located-that of Mr. Letout, the great cab proprietor at Kentish Town, and my name henceforth became "Bob," aye, "Old Bob," if you will.

IVe do work hard there, and no mistake; but get plenty to eat, such as it is, which is one comfort, for I always was a good doer; and, although our toilets are somewhat neglected, and our stables close and stuffy, we don't get used much amiss by our "horsekeeper" if we behave ourselves, although the terms we are occasionally addressed in are not precisely such as the ladies at the Hall would have made use of. But after a hard day's work, a horse is thankful to rest, and does not care too minutely to criticise his surroundings, so long as he has sufficient litter to lie on, and food enough to eat; at least so it is with me. I, too, am certainly lucky in my driver, for I know the old man thinks a lot of me, and if he does pretty often pull up for a nip of gin himself, 
he does not begrudge me a few extra oats at his own cost when he has been doing pretty well, and my share of the day's work has been exceptionally hard.

But my object in penning these lines, kindly reader, is not to abuse, or even expose, the shortcomings of my present surroundings; for I am not on the whole a discontented old horse, as I am, too, aware that I am not an unusually unlucky one; but to try, if possible, to prevent other wealthy horse owners, like Mr. Thankless, from so soon forgetting the obligations they profess themselves to be under to old favourites, such as I once was, and the good services that those have rendered them. To make them, too, consider what the future lot of such an one may be, ere they cast him for a few sovereigns in his old age on what to too many proves a rough world indeed.

My own lot is, perhaps, a happier one than that of the majority of well-bred horses that share my fate, for though I might not be passed sound by the whole of the Veterinary College, or indeed by any individual member of it, I am yet practically so, and hence my decade has not been a rapid one. But, oh! the poor breedy slaves that I see on my travels-exfavourites many of them, no doubt-but now collar galled, ill-fed and overloaded, and although doubtless 
forgotten, not, I fancy, forgetful of the past-for these I grieve.

But the end of the chapter must come to us all; and the tale of an old favourite (save the mark), like his life, perhaps, is very nearly spun out-my only remaining wish now being that I may either die gamely in my traces, as so many good horses have done before me, or else be led from my present rough lodgings direct to the dreary knacker's yard. I, "Goldmine," who was never to be sold!

But never to be sold, most forbearing of readers, you will agree with me, could have been more correctly and fully rendered thus: "Never to be sold so long as I could carry my I3 stone 7 master brilliantly in the first flight, or render him some other substantial service, and thereby save him from incurring the expense of purchasing another horse to fill my place."

Tush! it sickens me to recall his words; and I ask you, if you have followed my tale thus far, whether you are altogether surprised at my conduct this morning, now that you know the not uncommon history of a good old hunter.

$\begin{array}{llllllll}* & * & * & * & * & * & * & *\end{array}$

"Now then, 'Growler'" (he stands next stall but one, confound him), "stop that crib-biting, can't yer, and let a respectable hansom 'oss go to sleep." 


\section{CUB HUNTING.}

HE rain of the fore-night had moistened the ridings,

And threaded its way through the nut, briar and thorn,

Which soon shall re-echo the musical tidings That cubs to be hunted were here bred and born.

With twice thirteen couple of beautiful bitches Around him, see Jack at the bridle gate sits; His hack, if to safely encounter the ditches So blind as they are, should be blessed with rare wits.

A quivering stern here and there in the cluster, Denotes an old hound who Tom scarce can restrain From breaking away from the juvenile muster, So eager she is to be "at it" again.

But the grey dawn of morn's scarce succeeded the night

Ere the Master's arrived, and the hounds to Jack's cheer

Dash into the bracken, and spread left and right, And excusable quite is some slight riot we hear. 


\section{Eub 踔unting.}

How conies skedaddle, and birds utter notes

Of surprise at so early a hunt to get up !

But soon is proclaimed by the trustier throats,

That a fox has been roused by a promising pup.

With a shrill "Tally ho!" he is view'd o'er the riding, And scarcely a minute has passed ere Jack's there; The notes of his horn bring the pack, and he's gliding Along in their wake on his little blood mare.

A scent there is-hark to the gladdening chorus! And the wide rings hounds run also tell their own tale,

That the cub which Tom view'd is still forging before us ;

- His parents Ned watched steal away o'er the vale.

There are others on foot, little brothers and sisters, Who skulk here and there as the music draws near; But the bitches for blood are such heartless persisters, That change they will not with this scent, never fear.

A quickening chorus, a short muffled worry, Then silence proclaims what whoo hoop doth endorse ;

To save brush and mask Jack you surely must hurry, Though quickest of men, and on hardiest horse. 


\section{TLuo Copers.}

Whoo hoop! rip and tear him; whoo hoop! soon all's over;

But hark! there's a holloa-a holloa " away!" We surely are now quite in what is termed clover, Let's hope there's a scent in the open to-day!

There is, and for fully three miles do we scamper,

Though the fences are blind, in a very smart ring; At the brook in the vale one or two get a damper, But each one pronounced it a very quick thing.

A few turns in covert, and pug's life is ended, As fine a young fox as was ever pulled down; The keeper the litter so carefully tended

Our master has cheerily handed a crown.

The obsequies over, bright sunbeams come falling Aslant the green ridings and rackways, which say That huntsman and hounds must abandon their calling, And foxes, too, rest till our next trysting day.

\section{TWO COPERS.}

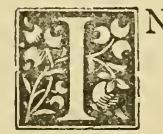

$\mathrm{N}$ committing the following amusing anecdote to paper, I will at once state that I am simply recording facts as told to me, and that I disclaim being in this instance the author of 


\section{Tivo Copers.}

the tale, further than that I, for the first time, I believe, lay before the public, as nearly as I can in their own words, the afternoon's experience of two Copers, not so very long ago, at a certain Midland Counties' Repository, which it is unnecessary to call by name.

The Catalogue, as usual, was a full one, and the numerous lots to be offered consisted of horses good, bad and indifferent, large studs, small studs, and single lots. One of the latter happened on this particular occasion to be a remarkably good-looking Brown Gelding, which was described-to quote from the catalogue itself-as Lot 39; the property of a gentleman :

"Harkaway," a Brown Gelding, 6 years, I 5.3; Quiet to ride and drive; a good fencer, and has been regularly hunted up to date.

Well, to continue my narrative, it was whilst Mr. IV. (a young, but by no means inexperienced member of the dealing fraternity) was in the box of the above described horse, that the portly form of the opulent Mr. B. also appeared upon its threshold. Now Mr. B. was a man of some note, through whose hands horses of the highest class often passed, and who was averse to buying, knowingly, anything inferior, or with an "if" about it. Mr. W., on the contrary, dealt in anything in which his keen judgment saw 
a profit was to be made, and to him a $£$ Io horse which he could sell for $£$ I5 next day, he not unwisely argued was a better bargain than a roo guinea one which he might have to keep for a couple of months for a possible pony's profit.

After both had looked Lot 39 pretty critically over, Mr. B., tilting his hat at the same time so forward that its brim rested on the bridge of his big broad nose, pompously thus held forth: "I wants this 'ere 'oss, W., and means a having of him;" and, having so delivered himself, awaited a reply from the younger man, who, less meekly than he expected, said quietly, "Do you? he does seem a usefulish sort, and I, too, means a having a bid for him myself."

"Now, young man," continued Mr. B. in his most patronising tones, "I says I wants him, and it ain't of no manner of use you opposing me, particular" (this coaxingly) "if I makes it worth your while to stand out."

"Right!" was the accommodating W.'s rejoinder, "give me a fiver if you buys him, and I'm no bidder." And in this laudable arrangement, Mr. B. having acquiesced, the pair parted, and in a few minutes the foreman appeared with his keys, the company cleared out of the stables, and the doors of the latter were duly locked.

There was the usual company present as the well- 


\section{Tivo Copers.}

known and popular auctioneer mounted the rostrum. In the gallery were a few ladies and the more influential patrons of the yard, whilst below a medley throng jostled and squeezed one another against the wooden hand-rail to catch a glimpse of each succeeding lot as it was run up the straw ride to meet its fate. Here was a parson who had brought a cob to dispose of, whose market value was perhaps I2 guineas, and whose description took up nearly a quarter of the catalogue; there a noble lord with a small conservatory in his button-hole, and farmers and dealers galore, as well as the usual contingent of horsey hangers on, who will beg anything from a pipe of tobacco upwards, and whose only apparent honest means of livelihood is leading a horse to or from the station, on the occasion of these bi-monthly sales.

But whilst I am running riot the horses are being rapidly disposed of, and at length to the bid of Mr. B. the good-looking "Harkaway" is knocked down for 45 guineas, and a very cheap horse he is, and $\mathrm{Mr}$. B. evidently thinks so, too, as is denoted by his self-satisfied expression, which only gives place to one of greater gravity when, a little later on, he is somewhat jocularly nudged in the ribs by young W., who, as usual, on business bent, thus accosts him: "Well, old boy, you've got a cheap 'un, anyhow ; shell out your fiver." 
But Mr. B. was, I am ashamed to say, very loath to part; he had got his horse, and IV. might wait for his fiver; these were his thoughts, and thus he replied: "The 'oss is bought, young man, but he is not sold, and when he is, I'll see as you 'as your fiver all right."

This was not "business," and both men knew it ; but after Mr. W. had informed his senior of the fact, and also that short reckonings make long friendships, and so forth, and all to no avail, I must, as a true historian, record that his further remarks were not only uncomplimentary, but also totally unfit for publication in anything but an organ like the P.M.G., the specialite of which is, or was, Social Purity.

"Revenge is sweet," however, says the old saw; and upon such, without a moment's delay, did our 'ossey and ginger-headed young friend turn his thoughts. He was a man of ready wit, and soon formed his plans; and, having done so, hastened to carry them out, by going at once to the box in which the bay was located, with a view to interviewing his attendant groom, who he found, as he expected, rolling up his clothing, stable requisites, etc., previous to departure.

"Is this 'ere 'oss sound?" was his first question, to which the groom, with perfect truth, replied in the affirmative. "Then do you want to earn half 
a guinea, young man?" was his second and more telling barrel; to which the stableman replied, with equal candour and more alacrity, "Rayther."

"Then," continued Mr. W., "a fat old chap what bought this 'oss is sure to come in to see you, and ax a lot of questions about him in a minute or two, and you let out, and do it careful mind, as how he makes a goodish bit of noise; and then that bit of gold shall be yours. D'ye see?"

$\mathrm{He}$ did see; and the bargain was no sooner struck, and young IV. well outside the door, than old $\mathrm{B}$. himself came wobbling into the long range of stabling from the opposite direction.

"Hey! young man," quoth he, as he approached the individual in charge of perhaps the noblest creature of the four we have been discoursing upon, "be you in charge of this 'ere 'oss?"

"I be, sir."

"He's a nice 'oss; quiet to ride and drive, I suppose!'

"Perfectly, sir, and a werry pleasant hanimal he is for either purpose." .

"I see he 'as bin 'unted, too; how can he lep?"

"The most beautifulest fencer, sir, whatever you set eyes on; there ain't nothing as comes no ways amiss to 'im, I assure you, and a child could 'old 'im." 
"Then, young man," continued Mr. B., eyeing him sternly, and speaking with great deliberationat the same time transferring a florin from and to their respective pockets- "ow his it as your master is a-sacrificing a waluable young 'oss like this for forty-five guineas?"

"Well, you see, sir" (and the groom never winced under the old man's gaze, but lied for all the world like truth*) "it's a thousand pities, but he just does this a bit"-at the same time imitating with his mouth a sound which most horse owners have heard more often than they could have wished.

"A roarer, is he-the devil ;" and having jerked the above remark out somewhat testily, and also muttered sundry other words, which I need not re-produce here, off bundled old $B$. in search of the aggrieved W., who, anticipating his movements, almost ran into his arms as he turned out of the stable door. "Young man," said Mr. B., soothingly, at the same time placing his hand in almost a paternal manner upon his shoulder, "it ain't no manner of use you and I a-falling out over'a blooming 'oss; I've been a-looking at him, and find, moreover, as he ain't so big by 'arf an inch as I laid 'im at, and consequently, nice 'oss as he is, he won't match the

* If this should meet the eye of a certain M. P., I assure him no insult was intended. 


\section{Two Copers.}

one I 'ave at 'ome, and wanted him for, and, therefore, you can 'ave im, my lad, "as I'm full of 'unters, and only bought him for a werry good customer of mine, what wants a match pair at once, but he's a particular man, even to 'arf an inch, or I could 'ave got three figures for the 'oss to-morrow."

"Well," remarked WV., somewhat carelessly, determined to give the big fish he had hooked plenty of line; and "Well!" shouted Mr. B. in response, with admirably feigned astonishment. "Well!" he repeated, raising his roice almost to a shout. "WVell! all you've got to do, youngster, is to get the Hauctioneer's clerk to re-book the 'oss in your name, 'stead of mine, afore I changes my mind, that's all the 'well' there is about it;" and then, with a gruff chuckle, B. rattled the loose coin in his pockets until the said chuckle gave place to what did duty in his case for a mérry peal of laughter-a sound similar to that emitted from an India rubber ball which, having been previously filled with water, is having the last drops uncompromisingly squeezed out of it again.

This merriment, however, was of short duration; IV.'s previously solemn expression now being cast aside, and a somewhat supercilious smile reigning in its stead upon his sallow visage, as he remarked, somewhat indifferently, "Why, they tell me he's a bull!" 
"What!" ejaculated old B., with mock astonishment, but, at the same time, well aware that his game was played out. "What, makes a noise! never heard talk of such a thing! you don't say so! dear me: dear me! and he don't grunt neither!" and then, after a few seconds spent in deep thought, in a pleading, disappointed tone, he proceeded: "Mr. W., you well knows that a roarer ain't of no manner of use to me; none whatever. I buys 'unters and 'arness 'orses of sorts and colors, but they must be sound ; but you" (with the slightest tinge of contempt in his voice, which he could not for the life of him conceal) "you buys hanything-heverything, so to speak-'bussers, cabbers, and what not; and a bit of noise don't make no difference to you, particular in one like that at such a paltry figure, for he's dirt cheap as he is."

"Not to me he ain't, guv'nor; but rather than you should 'ave such a 'oss on 'and, I could do with him at a price. What are you prepared to drop?"

"The oss is cheap, I tells you, as he is; very cheap," continues Mr. B., not even resenting this familar mode of address in his anxiety "to be out." But his arguments and assurances were alike all used in vain, for W. well knew that he had now all the tricks in his own hand, and meant to score his treble, which, to cut this already too long story 


\section{Tlwo Copers.}

as short as is now possible, I may as well state that he did, by securing after a good half-hour's bargaining the perfectly sound "Harkaway" for 35 guineas.

Thus it will be seen that the would be biter was very deservedly bitten. He would not, when he first purchased the horse really cheaply, part with the fiver he had promised to W.; but, subsequently, through the latter's cunning, was glad to give him Io guineas to take the horse off his hands; therefore, when the younger Coper had paid the groom the price of his lie (how rich some folks would be if they had Io/- for each they uttered!) he was the owner, not only of a clear $£$ Io, but also of a remarkably cheap horse, which, I think, after the anecdote I have related, we need not doubt he would dispose of to advantage.

As a story of the dog bite dog kind, this has, I think, few equals; but, although my tale is told, I must not close my note book without adding that, at a subsequent sale at the same Repository, W. took good care to circulate the whole story amongst the numerous dealers of their mutual acquaintance; and, from what I have heard, old B. (who was most unmercifully chaffed all round, and didn't half like it) had a roughish time of it that day. He will, however, I think, pay up on a future occasion, or, at all events, make a better selection of his man. 
The Carer of a §pur.

If this should meet his eye, and there are any trifling inaccuracies herein, I am open to correction; but question, nevertheless, whether he will care to "father" the story by setting me right, although I am sure the matters I have narrated will not have been forgotten by that portly personage, although it might be difficult for him to recall many of the numerous transactions in which he has been engaged when "the boot was on the other leg."

\section{THE CAREER OF A SPUR.}

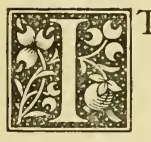

$\mathrm{T}$ is now several years ago, aye, some seven or more, but I remember the snug little double window in which I was then exposed to view, as well as if it were but yesterday. How superbly plated we were-that highly-burnished row of which my mate and I composed a pair! and Mr. Saddleflaps, in selecting a stand for our accommodation, neatly covered with scarlet cloth, had not displayed any lack of taste-for I trow that our kindred, even in the shops of the first saddlers in London itself, could not have outshone us-nor had they, I'll warrant, their silvery brightness displayed to greater advantage than ourselves. There we were perched in a row, watching day by day the 



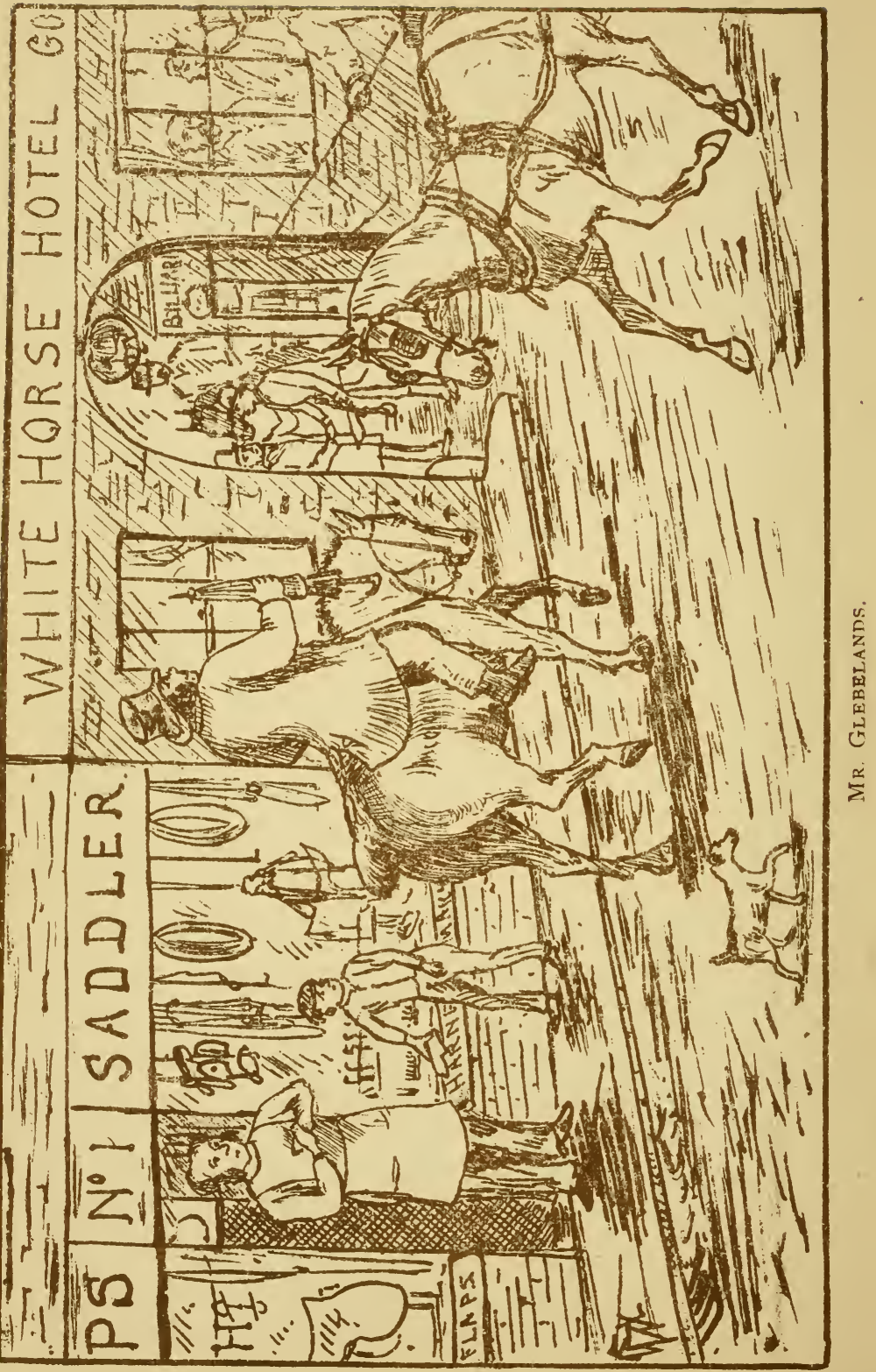


passers by, and the admiring glances of the numerous lookers in-our somewhat monotonous existence being only occasionally enlivened by a rubbing over with a somewhat time-honoured "shammy" leather in the hands of the latest apprentice.

Where, I wonder, are they, who were then my companions, now? There were those long swannecks-they went to Mr. Flickems, the dealer's, if I remember rightly; and those little wire-like racing spurs were, I fear, brought in the hands of Mr. Brewer, of the Dragon, to the low level of trotting matches. Then there were those little screw-heel black fellows, which neither we nor, I fancy, old Saddleflaps himself thought much of-they, lucky little dogs, although they had been kept up till the very moment of their sale shyly encased in brown paper, behind us-they were purchased by that good old country parson, Mr. Glebelands; and, before my departure from the little sporting town in which we lived, I used, in the cold days of winter, to gaze upon them with something akin to envy, as I watched them jog by on market days safely screwed into his reverence's well-polished heels, and with their murky little heads well buried in the shaggy-coated sides of that fattest and most tail-whisking of cobs.

$\mathrm{Ah} !$ mine has indeed been a varied existence since then! My butty and I were of the ordinary hunting 
pattern, and how well do I recollect, with several other pairs, being encased in tissue paper, previous to being forwarded on approval to the kennels of our local pack.

It was a bleak evening at the end of October, when old Sparks, the carrier, handed "our" little parcel over to Mrs. Hornblower, the huntsman's wife, and on the following morning four pairs of us were duly selected to be kept by the worthy partner of her joys. The rowels of one of these (for the second horseman I learned since) Hornblower scrubbed up and down the brick wall of his cottage in the most merciless manner; but it fell to our lot to be chosen for his individual use, and we, consequently, escaped such degradation.

How brightly we shone, too, a few days later when attached to as neat a pair of top boots as huntsman ever dunned! It was our opening Meet, and what a day we had, to be sure! As a matter of fact, it was absolutely my first day's hunting, and I thoroughly enjoyed it ; but hunting four days a week, as I afterwards did, the novelty of the thing soon wore off, as did also, alas! some of our thickly-plated silver.

I, however, flatter myself that before the end of that season I knew my duty as well as any of my metal brethren extant. Did I not, forsooth, almost instinctively wriggle myself into the sides of old 
"Nemesis" as a line of willows loomed in view; how "stickey" that old beggar was, to be sure! and did I not also, when boring through a hairy bullfinch, endeavour, by inclining my head outwards, to save, if possible, the flanks of that generous little Bay, "Balloon," from even an accidental scratch. Then there was old "Postman," who, although he was very good on the bank side of our country, used to land over every big fence into plough as if he had found his everlasting home; how quickly used my butty and I to implant our rowels into his wellarched ribs, and keep them there, too, until we obtained some other response than a grunt, which was not always a very easy matter.

Yet, during those three seasons, I must allow that I was once re-plated; but hard work is no disgrace, and will, if persisted in, tell its own tale on the best of us. What rare sport we had, too; for Jem Hornblower was a real good man-quick and clever when handling his hounds, and clever enough to let them alone also when they did not stand in need of his assistance.

But those dashing days are, alas! past and gone now, never to return; for every spur, like every dog, can but have its day. It was just about the first day's cubbing, at the commencement of what would have been my fourth season, that did for me, and it 
happened all through that confounded old woodman at Bushey Furlongs having neglected to trim up his rides and rackways as he should have done. The hazel boughs and briars completely met across many of them, and poor old Jem did "cuss" alarming as he threaded his way through the dripping leafy covert with head inclined and up-turned collar.

There was a scent though that morning, and the bitches had been bustling a fine healthy litter of cubs about pretty briskly for some time ere Charley, the first whip, gave a holloa, which made even the underbred little cub hunter Jem then bestrode prick up his slouching and usually indifferent roan ears.

"Come up," says the guv'nor; and through the brushwood we poundered as best we could, for that holloa he well knew signified that a cub was "away," and Jem was always an undeniable quick 'un to get to his hounds. With what a crackling of thorns and crumbling of soil did we quit the wood that morning, to be sure! I quite thought the clumsy little roan was down as he landed, after a scramble, with his fore feet in the field beyond, and his hind ones in the ditch. An entangled cluster of woodbine made me droop my swan-like neck, and an ungiving binder, alas! quite succeeded in tearing in two the weatherbeaten strap which the clinging briars had previously nearly severed from my less fortunate fellow. I could 


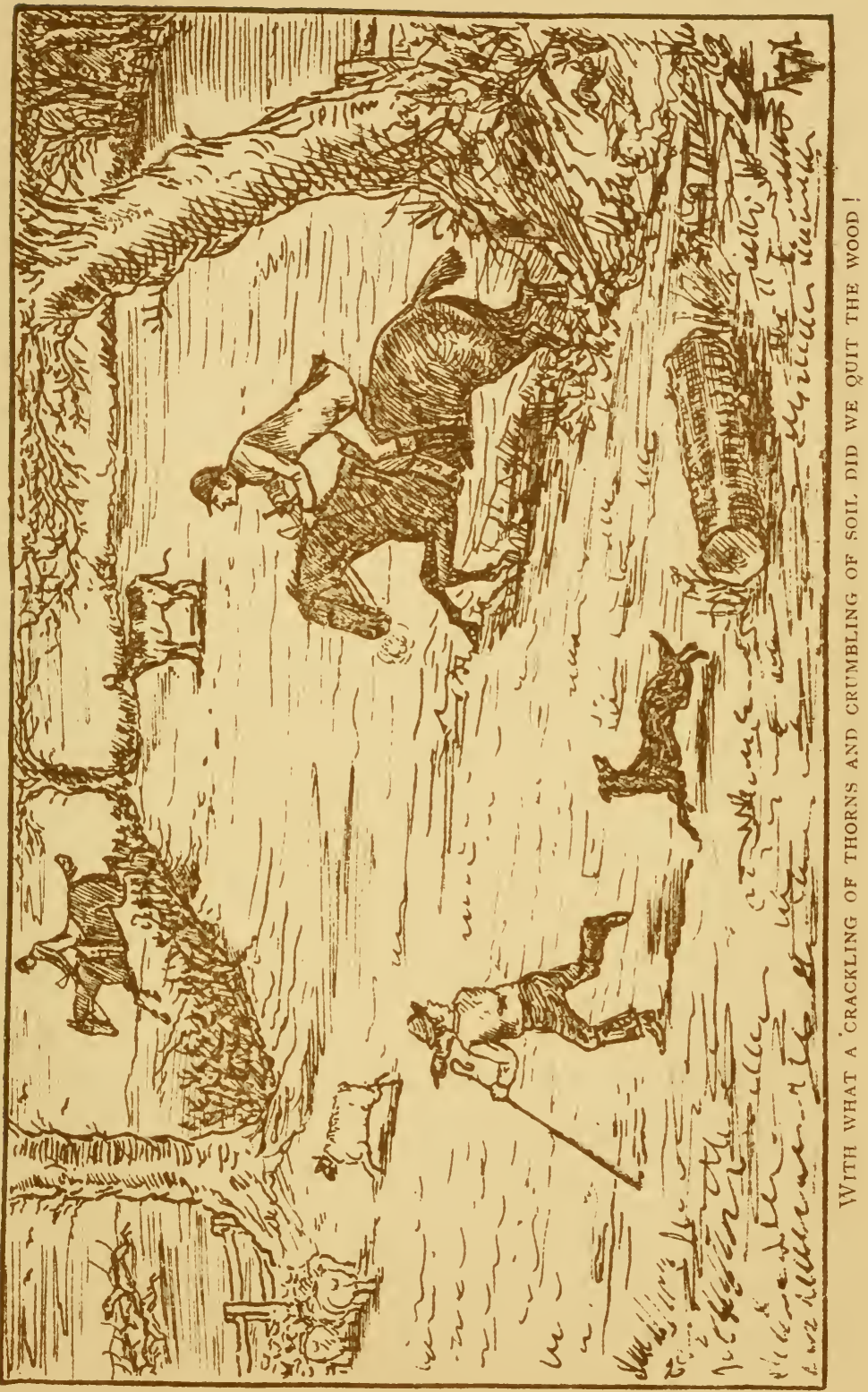



scarcely nod her farewell as she disappeared amongst the autumn leaves, ere I found that I had now myself double duty to perform in urging the little sluggard Jem bestrode to make the most of such capabilities as a not very notable ancestry had transmitted to him.

Yonder raced the fleeting pack, with Charlie sailing along alone in their wake, and if it had not been for me, and that fortunate bridle road, Jem certainly would never have caught them. We, however, did get to them after a stern chase of some twenty minutes, though only just in time to see the relentless little ladies roll over as fine a cub as ever was seen, within half a field of the hedgerow earth in which he was bred.

Alas! that was the last "whoo hoop" I ever heard; for the loss of the partner of my former joys but too surely brought my hunting career to a sadly abrupt conclusion. Farewell to you, my help-mate; I have often thought of you since, and wondered as to your fate. Perhaps you are still lying, and may for ever lie, in yon shaded dyke, undiscovered or disturbed; or I again sometimes think that a more honourable future may await you, and that, perhaps, one of your descendants, good reader, may, in years to come, find and cherish her as a quaint old relic of the past!

But to return to my own doings. Well, whether I was purloined by that boy or not I cannot say, 
Thy Carce of a spur.

but I next found myself, after laying neglected in our saddle room for some dreary weeks, upon the right heel of as saucy a little stable-boy as old Currycomb, our studsman, ever cuffed.

It was about Christmas-time, and he was riding old "Bones," the kennel pony, to see his friends at the town in which I first saw the light, and with regret I must record that I never set eyes upon those dear old kennels again. Tom Straps was that lad's name, and to a confounded little brother of his, who was learning the "butchering," was I by him presented that very afternoon. I well remember the little rascal, for although he was highly delighted with me, I was-although I don't think he knew itproportionately disgusted with him; nor do I hesitate to assert that herate a great deal more plum pudding than was good for him, and certainly imbibed too freely from the long black bottle devoted to the accommodation of currant wine. The indignities I suffered for a time on his hob-nailed heel, and upsidedown, too, I do not care to dwell upon, still less to describe the ungroomed, shambling hacks I reluctantly pricked along with such rowels as still were mine. But in these days even-though I say it, who, perhaps, should not-there must still have been something fascinating about me, for within six calendar months did not the rosy-cheeked, toddling 
daughter of Mr. Muttonfat himself becomedesperately enamoured of me, aye, and literally run away with me, too? Thenceforth my career was indeed a changed, and not even a horsey one, but I am very happy nevertheless, although the sole companions of my leisure hours are but an armless doll, a stuffed and squeaking rabbit, two ninepins, and a rattle.

My leisure hours, I may add, are such as do not find me being jingled up and down by a string over the uneven stones with which our court-yard is so indifferently paved. One thing alone, indeed, now disturbs the peace of my declining years, and that is a nasty, rickety and almost broken down spring cart, which, in charge of an unwashed and crosseyed Irishman, is not unfrequently driven past our shop. The whole turn-out has a rusty, disreputable appearance-from the ill-fed Russian pony in the shafts, to the dirty driver and very miscellaneous assortment of old metal on which he sits. I must own that my blunt old rowels turn more freely when that lot has passed, and the sound of those creaking, greaseless wheels has become drowned in the noisy humdrum of the surrounding traffic. But hark! I hear little footsteps approaching, and feel a strain upon my nearly plateless buckle.

"All right, Missey, I'm coming," and so I truly. enough am; for the little lady will brook no delay, 
and it is not my fault if my string does drag the poor old doll out of the box along with me, dislocating thereby its only remaining limb against the fender! But tug away, little Ada, and as long as you keep me out of that diabolical cart I will jingle as loudly on the stones, and hop as "jerkily" when you demand it, as the newest and most highlyburnished spur that now graces even the window of old Saddleflaps himself. For should we not, one and all, fulfil our respective duties as well as we can, let such be what they may?

There is, of course, a lot of difference between us two. I know all about that; but I yet hope that you and I, patient reader, possess our industrial share of "good metal," and trust, too, that when your head becomes silvered by age, your declining years may be as free from cares and troubles as my own, whose now almost rowelless head has long since lost its silvery brightness.

\section{DEPRESSION}

ISTRESS on all sides-landlords, tenants
too,
To battle with the times are quite unable; For most the chase is now no more, and few

Have even hackney left within their stable. 
How long, then, when its sinews are thus sprung,

Can hunting last, the sport of all sports' king?

How long shall still its thrilling scenes be sung,

Or who, alas! its funeral dirge shall sing?

The times are out of joint-the past is left,

But in the future's little food for hope;

Of England's Yoemen and her Squires bereft,

The chase can't long expect with fate to cope.

Not quite too late I've lived its joys to share;

I may not live to see its lustre die;

But feel its future never can compare

With the good times, alas! so quite gone by.

Those were the days when Squire and tenant met

In friendly rivalry at covert side;

When man and master could a living get,

And still unknown was emigration's tide.

Times those, when men were paid, and men could pay,

When land was worthy of its cultivation, When, with contentment, country hearths were gay,

And we degraded were not as a nation.

But all is changed; strikes rage where peace had reigned,

And unions spread, and treason's tongue's unchecked; 
'Tis wonder that our sport's so long remained,

When every day some honoured custom's wrecked. Would that prosperity could hasten back, And trade and farming hand in hand revive; That local fields could follow local pack, Fox hunting then would never cease to thrive.

\section{A DUCKING.}

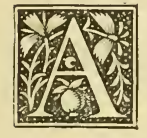

BACK WARD glance and a wayward swerve, and a skotching, halting gait, No responding spring to your hard press'd spur, as you try to hold him straight;

He yet can't swing to the right or left, though he would, as his ears shown plain,

And you cannot, ride him as you may, keep taut that bridle rein.

Shove him along, friend, best as you can, the planets aren't auspicious,

The brook is wide, and the water cold, and your quad is not ambitious;

But shove him along, and by dint of nerve and will you may land all right,

Though odds are greatly t'other way, that you flop in out of sight. 
* * Skotch—slide-splash! how the waters rise, like fountains in full play,

'Tis rather cold, you'll do very well if you scramble out of his way;

But, dripping, you've reach'd the wish'd for bank, and will cling to the bridle tight,

Give him tirne to breathe, then take a pull, one spring may put all right.

How he plunges! as the water drips from his craven, shining head;

"Come up, you brute!" How the mud lays hold of his legs in the stream's soft bed;

A grunt, a struggle, a jump, a sprawl, and you've landed him high, not dry;

Don't shiver by your nerveless quad, but to catch "the beauties" try.

At first don't bustle him overmuch, for it's knock'd him out of puff,

But show the horse that if he's a cur, you are made of different stuff;

So hasten along, friend, best as you may, till the streaming pack you nick,

Using eye, and head, and nerve, and hand, collectively and quick. 
Then if you're one of the happy few, when that shrill "whoo hoop" resounds

On the wintry breeze, what's a coldish bath if a means to get to hounds?

Have a hot tub when home is reach'd, and you'll feel no effects of the cold, And a "night-cap" take of water hot, combin'd with whiskey old.

\section{A FALL.}

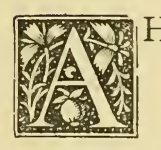

$\mathrm{H}$ ! that fatal ridge and furrow, then you felt his steps were out

As he near'd that strong laid rasper, fall you must without a doubt ;

Anxious seconds these, my brother, for collect him as you may,

You and I, who've seen disaster, know " a crumpler's" ours to-day.

Writers to the papers-theorists-may lay down some golden plan

To escape an awful "buster," but we know none always can ;

As he crashes the top binder, which, half yielding, holds you still,

You experience the preface to a most almighty spill. 
Have you time to loose your foothold in the stirrups, do so pray;

Be prepar'd, too, if it may be, quick to scamble from his way;

Down you come an awful crasher, how the ground shakes as you fall,

$\mathrm{He}$, alighting on his forehead, turns a somersault, that's all.

You perchance to left or right go, clinging still to bridle rein,

Rising, if without a fracture, not without a stinging pain ;

Collar-bone may not be broken-shoulder, p'raps, is not put out,

But it takes you a few seconds quite to know what you're about.

Never mind, old friend, hard knocks will meet us ev'ry turn in life,

And its joys may not out-measure in the balance all its strife;

But, re-mounting, you'll acknowledge, if you can regain your place,

That its rapture far outweigheth all misfortunes of the chase. 


\section{A CRUMPLER.}

LEAVED oak is not an item in the fencing way, I wot,

To be treated with derision, if a "greenish" mount you've got;

And should he elect to "chance it," and you, riding him with will,

Barely steadied him sufficient, trusting to escape a spill-

-But you know it! ere that creaking 'neath his upgraz $\mathrm{d}$ knees and chest

Does proclaim to you so surely that "a downer's" yours at best ;

One deep grunt, and then a motion acrobatic, and you see

Those four railings cleft but lately from the heart of oaken tree.

Scan them for a second only, gazing uproards, as your hat,

'Gainst the damp and scanty herbage, doth assume proportions flat;

You still grip that bit of pigskin, as you very shortly know,

For your horse is now upon you, and you camnot let it go. 



\section{A Crumplrr.}

For a moment he lies stilly; what a weight he is! and why,

As he makes that little effort, do you see stars shooting by-

Feel as, with a shake and scramble, he relieves you of his weight-

Feel a sick and dizzy swooning, which I can't precisely state?

Feel a whiteness in your visage, and a coldness down the back;

Feel, perhaps, as those of old did, who were treated to "the rack?"

Surely you have not been dozing; hulloa! there stands old friend Jones!

Is the other voice the Doctor's? Yes, one can't mistake its tones.

Oh! the pain-the pain in moving, as you slowly raise your head

From the roll'd up scarlet jacket-pillow of your dampish bed!

Yes, that brandy was refreshing-never mind about your horse,

He's all right in yonder hovel! You? your leg's broke-might be worse. 
Here they come, those sturdy yokels, bearing rugs and hurdle, too,

Which an impromptu "Sedan" is for no other man than you;

We'll pass by the pain you suffer as they lift you into place,

What a funny "feel" it gives you as you lie with upturn'd face!

But a good chap is the farmer, to whose house you're drawing nigh,

Borne along on willing shoulders, gazing at the leaden sky;

And the worst will soon be over, for at a few weeks at best,

After many pains and twinges, and a spell of miscall'd rest,

You will bid your host and hostess, who have nurs'd and tended you,

As your car stands at their threshold-bid them both, good souls, "Adieu;"

And, in some substantial manner, later on you'll take good care

That your gratitude express'd is, to that kind and homely pair. 
Then, next winter, in the saddle you will get, and go as well

As if what that day transpirèd, I had never had to tell; You will find the bay horse never "chance" again a timber fence,

Ride at such a trifle slower, and so show you've both gain'd sense.

\section{SOME EXCITING MOMENTS.}

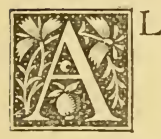

LL of us have experienced exciting moments at some time or another in our lives; let the latter, I take it, have been brief or long. It is, undoubtedly, an exciting moment to the African hunter when he finds himself confronted, and at no great distance, by the king of beasts; as it is also an exciting moment for the child as he watches his affectionate mother stealthily mixing "a powder" in a teaspoonful of seductive raspberry jam, and is unaware whether the concoction is destined for the consumption of himself or little brother! It is a vastly exciting moment to the soldier when a welldirected shell from the enemy bursts in near proximity of his own square, or battalion; as, too, is the moment an exciting one to the juvenile schoolboy, as he pulls, with eyes closed and quickening pulse, the end of a combustible cracker! But with such 
great and small matters as these I do not purpose to deal, although they (who will not aver?) are to their respective principals exciting enough.

Some of your worst moments have, I think, been spent when whizzing on wheels through the narrow streets of a thickly-populated market town; your charioteer being a fair one, whose company, at any other time, or under any other circumstances, you would have deemed yourself almost unduly blessed to possess. But, alas! when wielding those answering ribbons, as totally unconscious of her own incapacity as of your mutual danger-not to speak of that of the startled population, and corporation lamp-postsall that is changed! How each flick with the now knot-entangled lash causes you involuntarily to start, round your toes within your boots, or inadvertently clutch the side of the carriage! *** But there! you both survived it, although the rein did at length assume the position usually allotted to the crupper, and the consequences were, to some extent, disastrous. "It is an ill wind that blows no one good," however; so it is not surprising that the carriage and harness makers were more gratified by the manner in which you eventually terminated that drive than yourself, who are so persistently reminded of the circumstances from time to time by those confounded rheumatic twinges in your shoulder. 


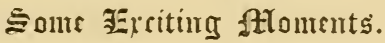

Dropping the curtain upon that scene, I will jog your memory as to another. You may, perhaps, not have wholly forgotten that little bit of rabbiting you took part in that frosty Christmas! They didn't bolt very well, you will remember; but when one did show its nose, or the tips of its ears, at the mouth of a hole nearly opposite to you, it would, perhaps, on the whole (no pun intended) have been pleasanter for you, if less exciting, had not the inexperienced and enthusiastic gunner on the reverse side of the fence so persistently caused his shots to rattle (luckily) past your gaiters!

But you then, too, returned alive, so all was well; although at one time you must confess that you did not think it likely to end so.

It was an eminently exciting moment also when, after that dance at their house-a gust of wind having temporarily extinguished the passage lampyou squeezed the hand, and whispered "sweet nothings" into the ear of Smith's wife, instead of that of her adorable sister. The more so, as your host, at the most critical moment, illuminated the scene by an inopportunely ignited match!

It was a moment, too, painfully and realistically exciting when, having in the smoking room overnight talked somewhat largely of your equestrian capabilities, you found to your discomfiture next morning, 
that you were destined to ride a young horse of your hospitable entertainer's, who just "wanted a man on his back, don't yer know!" The more exciting, moreover, as you inwardly and rightly felt horsemanship to be about the weakest of the numerous accomplishments in which you did not excel.

It was again, alas! a disastrously exciting moment when that childless and ailing old uncle of yours, Mr. Moneybags, whom you had systematically toadied and made up to from a boy, quietly called you into his snuggery one day, and asked you, conjointly with his butler, to be a witness-O, horror! a witness to his will!

These, or some such as these moments we have most of us experienced whilst trudging through this eventful world, and the subject is one, that in concluding this short essay, I may confidently leave in the hands of my readers to individually enlarge upon, or not, as circumstances, discretion, or memory may dictate.

\section{A PECULIAR BEING.}

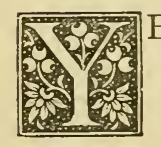

ES, I think I may so term myself, of course, in confidence, as I sit down, before throwing up the sponge of my literary and "Special" career, to make these few truthful revelations. I 


\section{A 豛enliar Zising.}

have come into a little legacy, and am, consequently, about to abandon my old vocation; yet I cannot, with a clear conscience, do so without to some extent unburdening my breast, even should I, by so doing, in some small degree expose the foibles of my fellow workers. Yes I am, or rather have been, a peculiar being-an individual, too, to whom more sport has fallen than to the ordinary run of mortals. Does any gluttonous Meltonian, who has regularly hunted six days a week, doubt that my words apply equally to such as he? If so, he is in error, for I unhesitatingly assert that I have not unfrequently hunted eighteen!

Eighteen days a week! yes, eighteen; but perhaps this assertion may, to the uninitiated, require some little explanation, more particularly as I am but the humble possessor of one useful horse (on which I hang my towels), and am seldom, except when at the offices of the Journals I represent, for many hours together absent from my happy villa residence at Brixton.

Yet a kind friend here, and a "tip" there, does marvels, and thus "from information received" I hunt, so far as the British public is concerned, eighteen days a week. On Wednesday last, for instance, I was in the first flight enjoying a clinker with the Pytchley, and jumping almost insurmountable obstacles with ease. This great run I record 
in that excellent paper, The Chase, in terms that make the ears of such keen sportsmen as missed it literally tingle; whilst in the same day's issue of The Hunting Horn and Clayland Chronicle are by my pen equally graphically described a smart twenty minutes with the Warwickshire, and a hunting run of merit in a woodland country more south; each run referred to having taken place on the same date; and so do I hunt on day after day from glad November till the season's close.

Occasionally, it is true, I have obtained a mount from a letter-out of hunters at a reduced rate, or from a dealer desirous of a "Notice" of his stud; but such are quite exceptional events, for (must I confess it!) I do not, except on paper, show off their horses to very great advantage, and feel a great deal more at home in my well-padded easy chair than their slippery pigskins. Hence it is surely hardly surprising that I have not unexceptionally been correct in my reports of sport; but as probably only one in every thousand of the readers of each Journal is in a position to contradict me, and as I always take good care to butter up the "big guns and influential duffers" of each and every hunt, what care I?

Carpet slippers, security from risk, and Brixton for me! To one of my tastes and means it is alike more enjoyable and profitable, and who, pray, is the wiser? 
It suits the public, poor gullable souls-answers the requirements of the publishers, and pays me, whose conscience, moreover, is probably as free from stain as that of most other "Special" knights of the quill. For does not our licence exceed that even of the Poets?

"Do you only hunt," I think I hear you ask, "when seated in your easy chair at Brixton?"

Not I, forsooth; would hunting alone provide a family man, like myself, with even the ordinary everyday necessities of life, let alone such little luxuries and creature comforts as I desire?

"What else do you do then?" is probably your next question, and I will hasten truthfully to reply to it. "What else! why 'puff,' of course, you innocent old scanner of newspapers." Puffing is the privilege of correspondents-the image of imposition without its liabilities, as, too, without a particle of its other dangers.

Don't confuse "puffing," my poor simple one, with the confectionery trade-the puffing I allude to is of a far more lucrative, though scarcely less "flowery" nature. Here is an instance of it :

"The day was, as a matter of fact, a cold one, and the wind North-East; but thanks to one of those excellent respirators, which can alone be obtained for is. 8d. from Messrs. Mufflemen, of Slum Street, 


\section{A łaruliar Zscíng.}

I, although suffering from a bronchial affection of long standing, was not, until my return home (when I consulted the thermometer and weather-cock), aware that the wind had been throughout the day in any colder quarter than due South, nor that the atmosphere had been the reverse of balmy," etc., etc.

For this trifling and more or less accurate notice, which I smuggle carefully in amongst some sporting matter, I receive a " note" of acknowledgment, with which I do not light my pipe; and for another, drawing attention to the superiority of Messrs. Bagwell's small clothes to those of all competitors, I receive free gratis for nothing, not only for inspection, but for use, a couple of pairs of those very serviceable requisites.

The same may be said indeed of all that is mine. I am, so to speak, a walking advertisement of goods, minus the price list, which I have but little doubt my friends would also much have liked to have attached to their respective presents, yet even I, a "Special," should, had it been suggested, at that indignity have drawn the line. Well! live and let live has always hitherto been my motto, and perhaps I am doing an injustice to my fellow scribes and our successors by making these confessions upon relinquishing so noble a calling.

Yet I cannot think that even these acknowledgments 
will shake ever so little the faith of the hungry and gullable B. P., for they always have been, still are, and always will be, so very, very gullable, God bless them!

Dear me! how we sporting correspondents are welcomed! Hotel proprietors have sumptuously entertained me free of charge! I have for years been clad costless from head to foot; and masters of hounds and others about to dispose of their studs have almost literally embraced, as well as very substantially rewarded me; but Ichabod, as I throw down my pen, so, alas! will my glory have departed.

\section{FARMERS AND FOX HUNTING.}

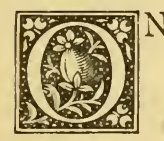

fox hunting and farmers both a great deal has been said,

A great deal has been written, and a great deal has been read;

Much twaddle has been spoken, too, respecting damage done,

And greater far regarding profits netted through our fun.

That oats and hay demand good price, no farmer will deny,

Nor sportsman, that they cost more now to grow than formerly ; 
That hunter's hoof on heavy ground oft leaves impression deep,

That hounds "full cry" do not assist one's fences neat to keep.

That now and then a farmer makes a good price of his horse

We know, but surely know as well that others entail loss;

On this head most of us must own there's been more cry than wool,

For in nine cases out of ten the dealer gets the pull.

That wire is permanent we know-out-lasts the oaken rail;

We know that foxes can be trapp'd or shot that roosts assail ;

We know the sport we love so well would quickly pass away,

If landowners and farmers both combin'd to say us nay.

So let us no more nonsense talk, but honestly confess That fox hunters do damage, and that foxes, too, transgress;

Instead of harping on the gain the studs throughout the land

Bring to the tillers of the soil, let's shake them by the hand, 


\section{Đid Carc.}

And thank them for the friendly way they tolerate our sport,

And hope to see them with us if they're of the sporting sort;

In any case let's spare their crops, and close the swinging gate,

Prevent their cattle straying, ride fairly and ride straight.

Let all who hunt subscribe to hounds, each as his means allow,

(Alas! look at our mighty fields, I ask is such so now?)

Then masters would not bear the blame to so-called sportsmen due,

Then losses would be fairly paid, and grumblers would be few.

\section{OLD CARE.}

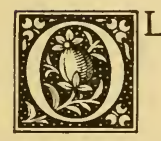

LD care takes a deal of unseating, He's hard to kick off at one's pleasure,

And a crushing big weight

To bear early and late

Depriving a man of his leisure ;

The rogue takes a lot of defeating. 


\section{- But a cure I will tell}

Grim old care to dispel,

An infallible remedy ever;

A fox hunting run

Puts a stop to his fun,

And his partnership quickly doth sever

The fox from the covert's seen stealing,

And a holloa proclaims he's away;

Then, pray, where is old care?

Surely left in despair!

He's supplanted by pleasure to-day, And happy, not sad, we are feeling.

Then a cure I will tell, etc.

The pack o'er the pastures is sailing, And the fences are high ones and strong;

The pace is, I declare,

Far too good for grim care,

And poor Reynard cannot stand it long;

The "field" is indeed greatly tailing!

\section{But a cure I will teli, etc.}

"Whoo hoop" is a sound grateful very

To many a stayer and jumper,

And of those who are there

We don't number black care,

So here's to fox hunting a bumper ;

No pastime's so healthful and merry. 
So old care we'll defy,

For, with hounds in full cry,

Sure the veriest duffer can pound him ;

A gap e'er so small

Will ensure the rogue's fall

From his seat at our cantle, confound him.

\section{HOW THEY COURTED.}

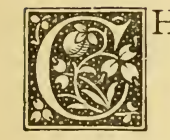

HARLEY HUTCHINSON was, perhaps, a bit of a rake, and yet there was never any real harm at the bottom of him, even at the time of which I write, when, having selected the army as a profession, he proceeded to devote the few months intervening ere his examination to, I fear, anything but attentive application to his studies. The fact is, that in addition to a strong partiality for billiards, rackets, and such other amusements as he could get in busy London, he had also fallen desperately in love, and that, too, with a very prepossessing young lady, residing temporarily at the Seminary next door but one to his Tutor's; and if the course of true love never did run smooth, Charley had no right to grumble at some incidents in his own courtship being decidedly against the collar. 
A chance meeting at a lawn tennis party in Clodshire; an accidental (?) one on horseback afterwards, and, subsequently, a few pleasant rides together through its shady, silent lanes had done the mischief, and, of course, it would now have been little short of "sudden death" to either of them had they not met or corresponded every other day or so. She was a pretty girl-was Kate Ponsonby-and if, after having seen nearly seventeen summers come and go, it was a trifle infra dig to have to search for your love letters neatly folded up at the bottom of a strawberry cream or lemon water ice, it was certainly better, as the more candid young ladies will allow, than not having any to search for at all. Yes, although the bottom of an ice was surely no fitting place for those warm-hearted productions, it was, nevertheless, their fate so to be located, for Charley had won the confectioner's young lady over to his interests, and found this to be the safest, if not most romantic, mode of daily communication; for Miss Robinson's fair charges always called at Thompson's for those delicacies (the ices I mean) during their daily constitutionals in summer.

Special communications to these charming creatures used formerly to be hurled through space attached to stones from Mr. Cramem's windows to the garden of the said Seminary; but as the stately 
Miss Robinson herself on one fatal occasion picked up and read a very affectionate effusion simply directed "For Kate," which chanced also to be her own baptismal designation, and found, subsequently and ruefully, that it was instead intended for her bewitching pupil, that sour-visaged old lady very quickly brought things to a crisis, which resulted in our friend Charley having to adopt the system I have alluded to, during the little time his idol and he himself were destined to remain in the neighbourhood.

It was not long, for Miss Ponsonby's health was pronounced to require a change (not by herself I may remark), and she was accordingly placed under orders to visit for a while an elderly and uninteresting Aunt at Brighton, whilst poor Charley, who was, alas! plucked for his examination, and no wonder, was doomed to twelve months' travel on the continent. These were truly trying times for both of them; but the quantity of pretty lace-bordered handkerchiefs that weekly swelled Kate's washing account it is not my province to reveal. The best of friends and truest of lovers must, alas! at times part; so suffice it in this instance to say, that old Smith, the Bath-chair man, was handsomely bribed to ensure them, if possible, an opportunity of finally exchanging and reiterating the old vows previous to their respective departures. "The powers that were" were much on the alert, 
but it came to pass in this wise that the young people cleverly frustrated their designs.

Miss Robinson's young ladies, as is well known in the neighbourhood, walked every Sunday morning to St. Peter's, which Ritualistic Church is situated some three-parts of a mile from the Seminary; and, on the day we are alluding to, pretty Kitty Ponsonby marched off amongst them, having previously with trembling fingers donned as sweet a little thing in hats as milliner ever sent forth into the world-its faintly pink-tinted feather corresponding admirably with the blushing, rosy cheeks beneath it. But scarcely had the usually decorous procession filed off from the establishment as was its wont, ere a somewhat shabby and decidedly innocent-looking Bath-chair was piloted by its perspiring proprietor, John Smith, alongside that very couple of young ladies of which our bewitching heroine formed one. Moreover, thanks to the diligence of its energetic custodian, it was enabled to retain that desirable position against the curb (which had been liberally bargained for), throughout this eventful march to Church, without raising in the guileless Robinsonian breast the most microscopic particle of suspicion.

It is not for me to record here the pledges which were exchanged under these favourable, if unusual, circumstances; but I think that Miss Ponsonby's 
companion, who was, of course, a confederate, must, during that little walk, have gained some slight insight into the mysteries of love-making, even if, as I much doubt, she had been previously totally untutored in, and ignorant of the art. To be brief, it was simply the old, old story over again of loving vorvs exchanged; and when the Church door was reached, and the last parting words had been spoken, each felt as supremely miserable as was natural under the circumstances, for in a very few weeks they knew that they were destined to be separated by as many thousand miles. Charley had not, however, been more than six months abroad ere he was summoned to return forthwith, on account of his father's severe and sudden illness; and on his arrival, after a rough and tedious voyage, at Devonport, he found a telegram awaiting him, acquainting him with the worst, which, in his case, commercially speaking, made him the possessor of a rent roll of some $£ 2$, ooo per annum, instead of, as hitherto, the needy controller of an allowance of as many hundreds. Letters of sympathy, of course, poured in to his mother and himself; and, as a matter of fact, in the sincere sorrow he felt for the loss of an affectionate and beloved father, the matters I have referred to above scarcely entered his thoughts.

Having, therefore, conscientiously transacted all 
necessary business, and carefully provided for the comforts of his sorrowing mother, our hero very soon again found himself ocean bound-the only addition to his former luggage, if one may use so inappropriate a term, being a rather nervously-written little note of condolence signed "Kate," which occupied, until his return home, a certain left-hand inner breast pocket, where it was considerably bumped against from time to time by a very susceptible organ indeed.

* $\quad * \quad * \quad * \quad * \quad * \quad * \quad * \quad * \quad *$

Twelve months came and went, and the bells of old Rankdown Church might have been heard ringing forth right merrily, as Kate Hutchinson quitted its flower-strewed paths for the old manor house hard by - a young and comely bride. Love had, as usual, scored a win, and even old Ponsonby himself blessed the happy pair as heartily at last as if he had not previously, after frequent skirmishes on the subject, utterly failed to gain Kate's very necessary consent to make a wealthy and obese banker his affectionate son-in-law.

* $\quad * \quad * \quad * \quad * \quad * \quad * \quad * \quad * \quad *$

It is some years now since the events which I have chronicled took place, but our old friends' pathway has been a very sunny one, and both "the Squire" 
and his "good lady" are only less idolized by the kind-hearted villagers at Rankdown than their two little miniature selves, who now lovingly toddle along at their side. The old Bath-chair never did a better day's work than that.

\section{IMPATIENCE.}

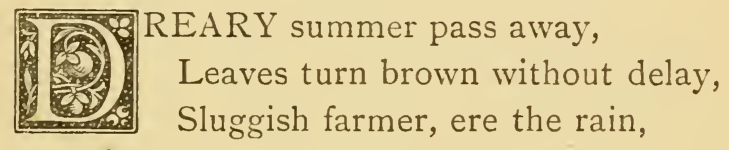

Carry home your golden grain ;

Clear the country low and high

As the sport of sports draws nigh.

Gladly shall I hail the day

When again we sail away,

Over oxers stiffly bound,

To the note of horn and hound;

Dreary summer let us part,

Winter only holds my heart.

Sorrow glides away when you,

Tardy summer, bid adieu ;

Winter, come! to many hearts

Your arrival joy imparts;

All true lovers of the chase

Long to see your honest face. 
Simp'ring summer, flow'r bedeck'd

Many hopes have you seen wreck'd ;

Yours the season is to court,

Ours the season is to sport ;

Welcome winter, hasten here,

Bringing that I hold most dear !

Then when hounds are running fast

We are freed from thought at last,

Then each heart forgets its care,

Be the future dark or fair,

Then we thorough bliss enjoy,

Happiness without alloy.

\section{THOSE DENTISTS.}

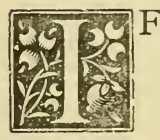

$\mathrm{F}$ the will be there, amusement, if only in a minor degree, can certainly be extracted out of most, if not all of the incidents of life. You will laugh when I say so-or, may be, shudder some of you-but even toothache is productive more or less of fun if you only go to your dentists in the right spirit.

Painful I know it is, but we poor human beings are heirs to all manner of ills, so let us as cheerfully as we can make the best of them. It is true that 


\section{Those 国entists.}

the extraction of a troublesome old grinder is very far from being "the sublimest of ecstacies under the sun," but, by and bye, if our little leases of life could be prolonged under no more favourable conditions, few of us would, I think, strike the clause, "Toothache and its consequences," out of the agreement, if by doing so we should risk its acceptance.

But to return to the bright side of the business. I have personally undergone the bother and the pain, the throbbing agonies and piercing tortures of an aching tooth, and yet have always managed to extract some little amusement, even under these unfavourable circumstances, from such visits to my dentist as have been unavoidable, and so, if you only would, most incredulous of readers, might you !

Fancy yourself, for instance, standing upon the uppermost of those three white and spotless steps, in the very act of ringing the door-bell of the renowned Mr. Tugwell, L.D.S.R.C.S. What a deplorable funk you are in, and what a cheerless expression you have assumed, which may or not, however, according to circumstances, be to some extent mitigated by the appearance of a smiling and comely serving-maid in response to your nervous summons.

"Step in, Sir, please. Mr. Tugwell will be at liberty in a few minutes." And don't you, as you 
enter the "waiting room," almost blush to own how heartily you regret that that estimable and able practitioner had not been engaged two deep throughout the remainder of the day!

On the table you will find a few carefully arranged books, consisting chiefly of poems and magazines of the goody order, from which latter you are at liberty to acquire sundry easily-extracted moral lessons should the former prove too light a species of literature for the delectation of your at present heavy heart. To-day's Times-as, too, some of the Illustrated Papers-is at your disposal, and mayhap also, should your adviser be humorously disposed, your inquisitive eyes are not unlikely to encounter upon the walls divers neatly-framed caricatures displaying fellow-sufferers in every possible stage of imaginable agony. And all these are provided, mind, for your entertainment, as, too, are the pretty landscapes which, suspended here and there, surmount the latter-and very fair specimens of their school they are.

But $O$ ! it is cruel upon the respective artists for their works thus to be brought to our notice, so I will not enlarge upon them further; but were I myself a landscape painter with any special style of my own, I would, before selling any picture, always ascertain that the would-be purchaser was not a 
dentist, or, if so, charge him very considerably more, for undoubtedly such pictures, or their likes, if seen again under the most auspicious circumstances will not inspire one with the same unalloyed feelings of delight as if other recollections were not brought very vividly to your mind by them as well. For, mark you, my good Sir or Madam, we contemplate them only before "the operation," and not after we have obtained the relief we sought. Then, you may recollect, we pay, and ungraciously hasten with scant thanks from the scene, and in our freedom from pain soon forget all about the brighter side of our benefactors art, if not his surroundings, in the humdrum of the busy outside world in which we mingle painlessly once more.

O that repulsive velvet-seated chair! O that ostentatious washing of hands! O that ominous napkin and blue glass thingemybob! That sewingmachine, knife-grinding kind of treadmill! That glass of nauseously tepid water! That bundle of spillakenlike instruments; and, above all, that prominently placed saucer containing gold-real gold! We do not forget one or any of you, if, perhaps, from after-consultation with our looking-glass we may have had, individually, grave cause to doubt the latter's extensive application in our own case. But no matter if the supposed gold hath subsequently a 
suspiciously leaden hue; we are all so thankful to be free again that we are not anxious to enter too particularly into such matters of detail, lest a second visit should be suggested by some more practical, if less sympathetic friend than the rest. And that is where these worthy dentists have such a pull over us. "Stopping" is all very well, but having a tooth out is the ordeal par excellence, though I question very much if, "taking one consideration with another," the patients, sufferers though they may be, do not have considerably the best of the bargain.

Put yourself, for example, in the place of the neatly-attired and amiable practitioner when vainly endeavouring to allay the fears of a dispeptic old female fossil of a highly nervous and spasmodic temperament; or, again, when trying to cajole a spoilt and rebellious juvenile into a suitable state of tranquillity. He has my sympathies, poor man, no less surely than he has their screams, expostulations, or even scratches! But when I once spoke on this head in terms of condolence to one of the craft, I shall never forget the bland manner in which the good man uttered this reply: "Yes, Sir; we do have to put up with a good deal at times; children, however, are more often than not the best of patients" (Fie on you nerveless sinners of maturer years!); and then, continued he with more animation, "but 
it is our business, and you must recollect that when we once get a firm grip on the tooth 'the game' is in our own hands." The "game," mark you ; and didn't his wontedly solemn visage light up with apparently malicious glee as the last sentence slipped glibly from his lips!

Well, at length all is over. You have had the old offender out, or have been otherwise bullied in probably little less degree, and take your departure, in nine cases out of ten, a very much happier man when you descend those well-scoured steps than when you mounted them an hour or less previously.

By the bye, do dentists themselves ever have toothache? And if so, who operates upon them? Dear me, what a lot of revengeful amateurs would volunteer if some of the greater of the professional bunglers advertised for executioners, if I may use the term! But that is in parenthesis, for undoubtedly the majority of us have, at divers periods of our eventful lives, been very greatly indebted to some skilled and careful operator. So I will hasten to close my book, lest I should be tempted, by enlarging upon the subject farther, to defeat the object I had in view when I commenced my letter; only, before folding it up, reminding you that the glimpse through the partially-closed waiting-room door as you don your hat and coat in the hall previous to departure is, 
perhaps, the most impressive, though the closing scene in your little dental drama.

There they sit, poor souls, with swelled faces and throbbing gums, eyeing you with unspeakable envy, and many of them only deterred by pure shame from rushing after you into the street, and so making good their escape, and if you do not, when you gaze upon that sorry group, re-echo very heartily the sentiments of the Pharisee of old it is a wonder ! G $\odot$ then to your dentists, my friends, determined, as I do, to look at everything through the rosiest of glasses; and to extract as much mirth as you can out of everything excepting his "gas." Depend upon it, this is the way to meet life's troubles, and your sorrows and pains, which are to a great extent imaginary, as also greatly magnified by an ignoble and anterior funk, will, you will find, very considerably be discounted.

\section{RIDING TO HOUNDS.}

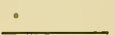

\footnotetext{
HIS is a subject which I do not venture to broach without much hesitation and many misgivings, as it is one which I feel that many older sportsmen, whose experience has necessarily been longer than my own, would be far better
} 
qualified to deal with. I, however, trust that if in the following pages much good advice may, as it certainly will, be omitted, I shall nevertheless not lead such as are willing to wade through this imperfect chapter into any very grave errors. If, on the other hand, a single pretext which. I may lay down should save an individual farmer one act of unnecessary or heedless damage, or the advice I tender to those whose ignorance of the science is greater than my own should cause hounds only once to be allowed those moments, when at fault, which are so essential to sport, then I shall feel that my efforts, however feeble and incomplete, will not have been altogether thrown away.

In the first place, I would impress upon you to give hounds room on all occasions - whether they are clustered around their huntsman's horse at the trysting place upon the village green, jogging along from covert to covert, or, as I shall further enlarge upon hereafter-at work. The cry of "Hounds, gentlemen, please," would seldom, indeed, be necessary if hunting men generally bore this maxim in mind, and the limbs of many a good hound would be saved from injury or fracture.

But we will now suppose that you have reached the covert side, and that the level and symmetrical pack has, to a wave of the huntsman's hand, dashed 
forward from his side like an opening fan to enter its recesses, where each busy hound will vie with its fellow in enquiring eagerness to ascertain the snugly sheltered whereabouts of that sly little red rover, whose front door has been so securely closed against his entrance by the careful earth-stopper overnight. But hark! a whimper! and yet another, and then what a melodious chorus as the pack, flying to an encouraging cheer, get at length well together.and settle down to work.

They have found-and if the covert is not a small one, and you are not (as in such case you probably would be) marshalled with the rest of the field to some particular corner of it by the Master, you had a great deal better get inside it; and by keeping your ears open to the cry of hounds as they pursue their quarry from one quarter to another, you will be able in your mind's eye to sufficiently accurately follow their movements, and will, as you do so, of course steer your horse through its rackways and ridings as those guiding notes may direct.

By this means you will more probably get well away with hounds than by any other, for even should a fox steal quite unobserved from the dense woodland we will presume hounds are hunting, their changed and clearer notes, when outside it, and relieved from the deadening influences of the over- 
hanging brushwood, will proclaim to you as surely as Jack's welcome "forrard away" has often done, that they have broken covert.

Moreover, if this plan was generally adopted, and the officials alone took up vantage points without it, how many more good runs should not we have to record, and how seldom should we be doomed to sit shivering in our saddles until a good fox, heartbroken from being so constantly headed back after repeated rings around it, was eventually pulled down within the precincts of the covert he was in reality only too anxious to quit an hour before.

Scent we cannot ensure; but many a run, which might otherwise have been a clinker, has, on a good scenting day, been spoiled by the heart of a good fox being broken before he has been able to get away from covert. At one point he possibly encountered some cunning sportsman sitting down wind eager for a start; whilst at another, as he neared the border of the wood, his intended course of action had to be abandoned owing to the silly prattle of some noisy group, or splashing patter of hurrying horseman along the headland without, attracted by the now approaching chorus of the pack. Persons thus acting, although they no doubt professedly come out to partake in a day's sport, do, as a matter of fact, as much individually or collectively to spoil 
that of themselves and others as lies within their power. The rides may be deep, and probably are; your beautiful toilet may, and possibly will, get soiled, and your horse, too, have a little of the gas taken out of him by floundering through a bog here and there; but what have you come out for? I will conclude "Sport;" and to such only as are, or would be, sportsmen do I address these remarks.

Very well, then, let us suppose that you, like the majority of us, have but one horse out, and that you are also no less humane than you are keen. Answer me then, if you please, these straight-forward questions: Would you not rather pound him up and down this deep woodland, say for some fifteen minutes, and, subsequently, by having done so, get well away with hounds, and have a right good gallop after a bold and mndaunted fox, and then (if advisability so dictated) go home satisfied? or would you rather, by dodging about outside the covert to avoid the temporary inconvenience of encountering its sticky ridings, spoil (as you or some other individual acting similarly are almost sure to do) the sport you have nominally come out to see, by heading back or otherwise preventing the fox from making his intended point? Even should he succeed at length in breaking covert at all, and you personally have the good fortune to get away with hounds, recollect that the fox which 
they will then pursue, instead of being the brightcoated nimble animal you stared in the face some half-hour back, is (though in reality the same) but a miserable, panting, heart-broken, draggled object, the best of whose strength has been already expended in avoiding you, and such as you, and who cannot at best be expected to stand up before hounds for long, if he does not, as is probable, take shelter in the first dry drain he knows of, but a few fields distant. Whereas, had he made his point good when he first essayed to break; had you, that is to say, been inside the covert instead of without it, those rare powers of endurance which he then possessed would have been expended in giving us all a run worthy of the name over the beautiful and surrounding vale, which wished for contingency your selfishness or ignorance has alone changed into the morning's doings which I have passingly alluded to as probable. Yet, notwithstanding all this, you will as likely as not have the audacity to style that fox a bad one, whose inability to provide sport you were alone responsible for. "A bad one!" forsooth; the epithet, I think, might with more justice be applied by other sportsmen to the utterer!

But let us now imagine that you have either acted as I direct, or that reynard has, with even more than his proverbial slyness, found a corner of the wood 
from which to make good his escape without hindrance, and that Tom, who sat motionless as a statue until he was fully a field and a half away, has now acquainted you, by his upheld cap and that heart-thrilling holloa that has so often cast cares and cigars to the winds, that he has gone. Toot, toot, toot! twang, twang, twang! goes the huntsman's horn; and now "Columbine," now "Affable," closely followed at short and diminishing intervals by the remainder of the pack, come dashing as best they may through briar and bracken, each eager to be first. The huntsman may, and probably will, gallop forward with the few couples of hounds soonest out of covert, and by cheering them on and sounding, from time to time, those shrill, yet musical notes upon his horn, will, doubtless, without much delay, have the remainder, which Ned's rate in covert is hurrying forward, in their wake.

But you, my friend, will not, like that tailor yonder, gallop after him. No, on the contrary, if you do not, as you should, open that bridle-gate to hasten the egress of the spotted beauties struggling in hot haste to climb over or through its opposing bars, you will, at all events, restrain your ardour until the body of the pack are well away, and then, when with that melody which no pen can do justice to, they settle down to business in real earnest, so may you. 
Be quick always, but never in a hurry; be eager to excel in this as in all else you undertake, but do not, I prithee, be jealous. There is room for all here; your course is not flagged out, but yet you may from time to time, from one cause or another, notwithstanding, have to encounter your fellows crowdedly and anxiously pressing to get forward at gate or gap. If, however, you are made of the right stuff and wish to see hounds run, a little courtesy, though it may delay you for a ferv seconds, need never deter you from doing so, and it is usually noticeable that those who, on these occasions, push forward with most rudeness and avidity, are such as are least capable of retaining such a prominent position when secured. Always, however, as far as is compatible with discretion, take a line of your own, and avoid such "jams" as these. Your horse, when accustomed to do so, will jump better, and you will have, in addition to the satisfaction of seeing hounds run, the pleasurable knowledge that you are indebted to your own eye and intelligence alone for such position as you may hold.

There is a scent: Now ride, not at hounds or over them, not emulous of being in front of this friend or of that, but a little to the right or left of the line they (the hounds) have taken, and always keeping an eye upon their leaders. I am writing of no 
particular pack, so may be excused for saying that, with a scent like this, the symbolical sheet would not, perhaps, always cover them; and should the fox they are following so thread his course, the man who watches the leading ones will, in all probability, ride the line which would form the base to the two sides of the triangle he has run, whereas he who steered his course by the tail hounds would, with equal probability, have to traverse the former distance, and even we, who have forgotten most which Euclid taught us, can have no doubt as to whose horse would have the longer journey of the two.

If hounds should check, only for an instant, and you are anywhere near them, or anywhere to right or left where the fox may have crossed, check your horse too, and instantly, and stand perfectly still. Not a word must be uttered now, and then, in all probability, your inaction will prove but momentary, for the hounds having cast themselves, as they are sure to do if neither pressed on or interfered with, will, in the majority of instances, recover the lost line of their fox without any assistance whatever, and the good gallop you are enjoying proceed without noticeable interruption.

Should they fail to do so, however, as they, of course, from divers reasons often may, the huntsman will put his horse in motion to aid them, but this is 
no signal for you to do the same; on the contrary, it is incumbent upon you to remain where you are, for the fox may have doubled short to the right or left immediately in front of where you stand, and scent is a thing under ordinary circumstances difficult enough for those delicate and carefully-bred noses to detect without the "added weight" of a foiled line being laid upon them, as would be the case were your now steaming horse to cross it.

Never, therefore, follow a huntsman when castingalways excepting with your eye-or, at all events, never do so until the ground has been "made good" on to which you purpose changing your position. When, however, the huntsman has, from cattle stains or what not, failed to recover his fox's line in the near vicinity of where hounds checked, and makes a long forward or wide scientific cast, it is, I think legitimate for you (not pressing upon him, mind) to yet keep the pack sufficiently within your reach to enable you, should they suddenly again hit off the scent and run, to shortly regain such a position as would allow you to see them do so, which is, or should be, the object of your presence in the hunting field. But, as I before remarked, be sure that the ground on which you are about to advance will not be required for any future operations of hounds and huntsman. 
How many indifferent runs would have been "red letter" ones, I wonder, had this course been generally adopted; and when I think how short life is at best, and how by far the most joyous of its fleeting moments are spent in riding to hounds, it is, indeed, grievous to recollect how blind by far too many of us are to our own interests and to those of the sport we love.

But hark! a cheer from IVill pronounces that Bonnylass has set matters right, and we must now put our horses in motion, and again ride with such nerve and discretion as we may individually possess, for although to do justice to the pack is our first duty, to do justice to our horse is no less certainly our second. So now for a few words on that head.

Make up your mind as soon as you enter a field where you purpose quitting it, and do not alter such resolution unless the hounds suddenly change their course, or from some other equally good and unforseen cause. Pick the best, that is, the easiest exit from each field which the direction hounds are taking permits of, and never ride too close behind another man, or, in other words, always allow sufficient interval in which with certainty to pull up your own horse should his fall. Always, moreover, try to keep as close to hounds as is legitimate with as little exertion to your horse as is compatible 


\section{Iniding to 筫ounds.}

with so doing. To do this, you will pick the soundest "land" or the wettest furrow to ride upon, as that, too, is necessarily the soundest at bottom; and by carefully economising your horse's jumping and other powers you may reasonably hope to generally, I think, see the conclusion as well as the commencement, or a part only, of the good runs a season will provide.

Regulate the pace at which you ride at the various obstacles you may encounter to their nature, and the condition of the ground from which your horse has to spring. To ride slow at timber and fast at water is advice as good as it is old, and if you do not adopt the former principle also at blind places-banks and walls, and in leaping from very deep ground-I fancy that sooner or later you will be reminded in an unpleasantly rough manner that it will be advisable to do so. Brooks and wide big places generally, of course, require pace; but, I think, in nine cases out of ten men err rather on the fast than the slow side in our flying countries, and that horses would generally go stronger and longer if a little steam was shut off rather than turned on as they neared their successive "leps;" but different horses jump best in different ways, and an ounce of experience will go farther to help you in these respects than reams of the best intended letter-press can. 
To get to hounds and keep with them are the objects a sportsman must have in view; he does not come out to go leaping a lot of monstrous places straight on end, in order to pound Jones or Robinson, or, subsequently, even to enlarge to Brown on the performances of himself and horse. Such "gallery" performances as these are more adapted to the show ring, where they might be indulged in without detriment to sport, and certainly before a more appreciative audience than a field of "sportsmen."

To live with hounds throughout a good run, or, indeed, any run worthy of the name, must depend chiefly, I grant you, upon yourself, although also, to some extent, upon the horse you are riding. Some men can get to hounds in comparative safety on almost any cattle, provided they have "condition;" but this gift does not fall to the lot of many. More often, indeed, do we find men with everything in their favour-horse, knowledge of country, and even nerve-who will almost invariably fall, get thrown out, or from some other cause lose the position they coveted and certainly ought to have held.

If your horse is, you know, undeniably bad at timber, shove him promptly through the bullfinch to the left, or even turn slightly out of your course to negotiate the two small fences on your right, in preference to risking an almost inevitable fall over 



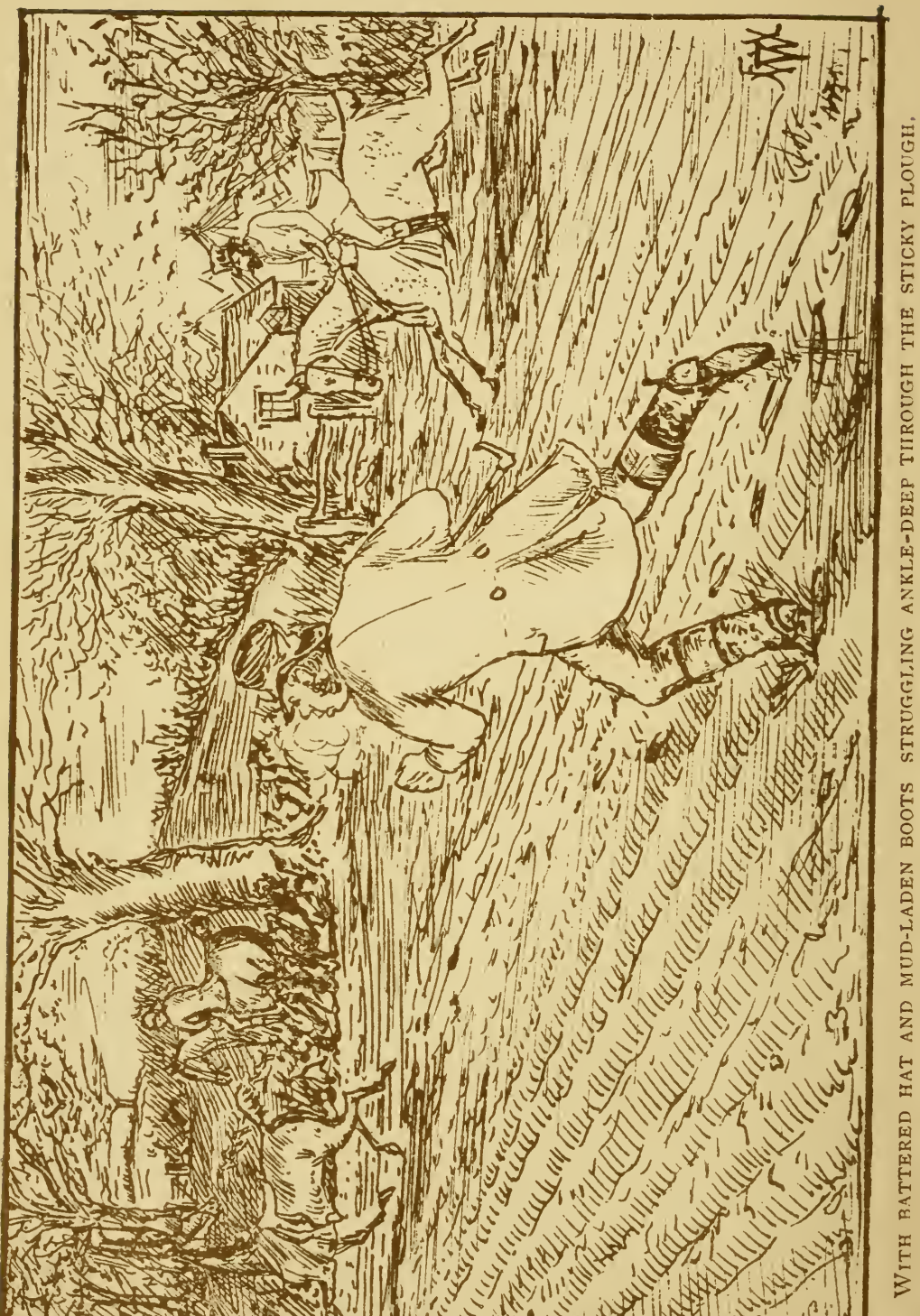


that hog-backed stile. Never mind the jeering "Come on, old fellow! it's all right!" or what not, from Smith, who has cleared it in front of you. You are not bent upon a pounding match if he is, and to carry out the object you have in view you will find it quicker, as well as better, even to deviate as I suggest, as it will assuredly take less out of your horse than if, having charged that awkward bit of timber, you had succumbed, as you had good reason to anticipate. Picture to yourself the pack streaming away over the brow of yonder hill, and you, my friend, with battered hat and mud-laden boots, struggling ankle-deep through the sticky plough, in apparently hopeless pursuit of your vanishing steed, and I think you will allow that discretion in such a case may prove the better part of valour, although fortune not unfrequently favours the foolhardy as well as the brave.

If you come to a really big brook, and either your own nerve is wanting, or you deem your horse unequal to negotiate it (the former, you bet!), ride at once, if you don't mean to risk a ducking, to the nearest available ford or bridge, but don't, pray don't, ride half-heartedly at that streak of running water, for by doing so you will ensure ysurself either a cold bath or "refusal," and if the latter, probably will potter about on its brink watching hounds sail away from 
you, as you stand there like a child ruefully viewing a toy boat upon the Serpentine, the string to which has become detached. No, ride at it manfully, and get over or into it at the first attempt, or with as much determination, if less valour, shirk it at once.

No run is so good as to warrant your leaving a human being hung up in his stirrups, with his horse atop of him, in a ditch, or in any other position of actual danger, but it is not incumbent upon you, if hounds are running well, to lose your own place by riding out of your way to catch the runaway steed even of a friend, although it would be undoubtedly an act of great kindness to do so. Grasp the horse's bridle, if you can, as he rushes past you, and hitch him up by its reins to the nearest gate-post, if no yokel is at hand to take him back, and I think you will have done your duty; unless in the case of the huntsman, when an action of self-sacrifice is, I think, incumbent upon you; and gallantry would dictate a similar course to most were the empty saddle a sidesaddle.

But you are "down" yourself, we will suppose, and of course, if possible, will retain as firm a loold of your reins as you would of a solitary plank if similarly wrecked at sea; for as that would be then your only apparent means of safely reaching the shore, so, assuredly, is your horse now the only means by which 


\section{Liting to 跑otmos.}

you can possibly hope to overtake the flying pack.

"Are you hurt?" "Yes." "Much?" "No." Then don't bother and delay your kind and enquiring friends; let them get on, and do the same yourself, if able, as soon as possible, and try as quickly as you can to make up by your good eye and knowledge of country the ground you have necessarily lost. If, however, your fall is worse than this-a serious one, in fact-say so, and sportsmen will not be found wanting to assist you, gallop for the doctor, or what not.

Should you (and it is at times unavoidable) lose your horse, it is worse than useless running after him ; for, active as you may pride yourself on being, you cannot overtake him; whereas, if you walk leisurely forward in the direction he has gone (which will probably be that of the hounds), the chances are that you will very shortly meet a labourer bringing him back to you, and, having rewarded him, will be able to re-mount and get forward with far less delay than if you had hurried more, and renewed your mutual partnership even a trifle earlier, when you would have been considerably more out of puff than your re-captured steed himself.

But reward that countryman liberally, for remember that one friend so gained to sport may at some future day be the means of saving the life of some good 
fox, who, having been marked to ground and left in some village drain, would assuredly have been worried by the terriers of his friends but for his very timely remonstrance.

Never ride your horse to run the risk of either killing or injuring him from over-exhaustion. In a huntsman (though seldom) duty may compel an undue strain sometimes to be put upon a generous horse, but in your case never. To a horseman of the most ordinary experience and observation there can be no mistaking the rolling gait, dead, heavy pull at the bridle, and chancey jumping of a "beaten" horse. who, more often than not, when in distress, will, if a generous one, rush at, rather than try to shirk his fences; but do not mistake this apparent eagerness on his part for capability of proceeding further, for it is nothing of the sort, only, indeed, often being by one short stage removed from the actual "full stop," stiffened neck, quivering tail, dilated nostrils, and extended feet, which denote exhaustion so complete that neither. the brutality or ignorance of the rider can induce him to proceed farther.

But this stage should never be arrived at by you. You hunt for sport, and sport, when it becomes cruelty, is unworthy of the name. That "spurs are for use, and not abuse," has been wisely said; and if nine men out of every ten were to ride without 
them, it would, I venture to think, be more conducive to their own safety than otherwise. Those who are qualified to use them, and, consequently, do so judiciously, would, moreover (except in the case of vicious and exceptionally sluggish and ungenerous horses) find that considerably blunter ones than those usually in vogue would answer their purpose (that is, of implying that some extra exertion or increased speed is demanded of your horse) equally well, and many an unsightly and painful scar caused by a lost stirrup or unyielding grower would be avoided.

But let us now surmise that poor reynard has, at length, succumbed, and that IVill's shrill "Whoo hoop" has resounded o'er the vale.

The run has been a fine one, and we have all enjoyed it, but his last moments were, I am willing to admit, not happy ones, although his agonies were of but short duration. But, fair and gentle reader, I would point out to you that his lot has not been through life a hard one, and that he has been preserved and spared in many ways for the especial purpose of affording sport, and that his numerous robberies and other discrepancies have alone, on that account, been overlooked. Moreover, had such not been the case, he would, most undoubtedly, have met his end ignominiously, after prolonged 
tortures in a trap, from treacherous poison, or equally possibly have succumbed, after lingering suffering, to the effects of some vital gunshot wound.

Remember also, and beyond all else, the amount of healthy pleasure he has given to men, hounds, and horses (if properly ridden); that the odds on his escaping from the pack on each occasion that he may be hunted, are, from lack of scent and other causes too innumerable to mention, very greatly in his favour; and also recollect that the noblest of our sports, in which he plays the principal part, does much good commercially to numerous branches of the community, cements good feeling between all classes, and is, in addition, as the great Duke of Wellington said, the best school for cavalry officers.

But our sport is over for to-day, and, having been deprived of brush, mask, and pads, the shapeless remains of that once bright little rover are thrown aloft to be worried on their descent by the baying pack below. You have long ere this, doubtless, dismounted, eased your horse's girths, and turned his head-if at all blown-towards such breeze as there may be. Now keep him well out of the way of the relentless little bitches as they dash hither and thither, tearing their vanquished foe greedily into tattered fragments on the sward. Keep your horses well out of their way, for most dislike the smell of 
blood, and the quietest even might err under such trying circumstances, and to kick or otherwise injure a hound now, would be, I am sure, to spoil a day's sport, upon which, otherwise, you would look back in years to come with pleasure in your diary.

But all is over now, so tighten your girths ever so little to admit of your re-mounting, wish good day to your friends, and turn your game, good horse's head for home, regulating the pace at which you proceed thither to the exertions he has undergone and the distance to be traversed.

You can lay down no rule on this head, but if he is not really distressed, I have found myself that from six to six-and-a-half miles per hour usually about meets the case, for it is better, surely, to get him back to his own box half-an-hour earlier, than to delay his return to home and its surrounding comforts by crawling thither out of misjudged kindness at a still slower rate. If your horse is distressed, ever so little, or even only blown, do not hesitate to let him wash his mouth out at any clear running stream; he won't swallow much with his bit in his mouth, and what little he does will not hurt him, but, on the contrary, refresh him a great deal, by cleansing his mouth and lips from such foam, etc., as is usually attendant on severe exertions. If you stop to give him gruel on your way home, which you 
may with advantage do should the day have been a hard one and the journey still before you long, see that the oatmeal is mixed first in cold water, and the warm subsequently added, as, if the reverse process is adopted, it will he both lumpy and indigestible. Should you, too, deem it desirable to put him on the straw for a few minutes, you will do well to-if far from home-remove his bridle, and give him, in addition, a few mouthsful of sweet hay or clover. A tired horse will pick such over more readily than he would enconnter any more solid food, such as oats, peas, or beans, and it will answer the purpose equally well, or better, in such a case.

And now I must allude to a subject which, in order of importance, ranks very differently to the position I have for convenience allotted to it in my notes. Be most careful when out hunting to do as little damage as possible. Avoid riding over wheat, seeds, vetches, beans, and other crops, as far as you can; use your best endeavours to prevent stock from straying, and to such intent, if "last man" (as I trust you may not be), close all gates through which you may pass, and be particularly careful in latching such as open on to lanes or highways. If you possess one, moreover, instruct your second horseman to do likewise, and, in addition, to wait back (as he often may without detriment to your interests) to do so 
on occasion. If you should meet with any opposition from either the tenant or proprietor on whose land you are, acquiesce in his wishes with promptness and civility. You may lose your own place in the run by having to diverge, or even turn back, but you will not have driven a nail into the coffin of sport. Always avoid riding over garden ground and allotments, and if forced to cross wheat or other sown ground, ride as much as is practicable along the furrows, as in crossing fields of roots between the rows, for recollect that those which your horse's shoe bruises will decay when the next frost comes.

A hunting man, who is indebted to so many for so much, should, moreover, above all things, be liberal, remembering when dealing with his neighbours that "one good turn deserves another," and that hunting must exist, if at all, on very elastic principles of give as well as take.

Our sport flourishes, and can only continue to do so from general all-round good fellowship; and in the little cottage child who runs to open you a gate, recognise a supporter of the sport, as (if in a necessarily less marked degree) in the noble master, who, at his own expense, provides it for you in so princely a manner. The endeavours of each should be appreciated as they deserve.

Let us, moreover, individually see that by no dis- 
courteous or other act of ours we do aught to weaken its foundations; but, on the contrary, by forbearance and well-timed liberality, do as much as lays within our power to maintain its present popularity with all classes. I would also remind you that there are but few occasions on which it is legitimate for you to render assistance to the huntsman unasked, by either turning hounds to him or even checking riot. It is the duty of the whippers-in to do this, and you had better never interfere with hounds' movements unless requested to do so, or unless you, from long experience and knowledge of the science, feel yourself to be sufficiently discriminating to so act only when your services are urgently needed and would be welcomed. But to such I have not addressed these remarks, so need only add, for the benefit of the less experienced, that there is, perhaps, one exception to this rule, and that is this: Should you find yourself alone with only a ferv couples of hounds running in full cry in one direction, when the huntsman with the body of the pack is clearly hunting another fox in a totally different direction, and no whipper-in is within hail, I then think that it is your duty to stop them, and having done so to, if possible, coax them after you in the wake of their fellows, and before long you may, and probably will, encounter a whipper-in riding back in search of the 


\section{Lioving to 3 giounds.}

delinquents, who will be indebted to you for your trouble.

It would have been, I dare say, more gratifying to your vanity, and pleasant enough, to boot, had you sailed away with, and hunted that little pack yourself; but "the huntsman's holloa must be maintained," as Beckford, I believe, says, even if by endeavouring to do so you or I may individually find ourselves absolutely the last of a scattered field, instead of being in the enviable position styled "alone with hounds." Should you, however, from any cause fail to effect your object of stopping them, hasten to where the body of the pack are, and acquaint a whipper-in at once where you last saw the divided portion of it, and also the direction in which it was then pointing.

Still one word more, for I must not close my note book without adding a few lines on the subject of view holloas.

If hounds are running a fox in covert, and you view one cross a riding therein, or break away, you had better in the first instance not holloa at all unless convinced that it is the same fox hounds are running, and in the second, having holloa'd him "away" sufficiently clearly to catch the huntsman's ear, be silent, unless by his responding horn you know he means, if possible, to get the pack away on that 
fox's track. Then you may air your lungs for a little longer period, as by doing so your voice will guide the huntsman where to ride, as his voice or horn will in turn direct the hounds to the same spot. Be very shy of holloaing when a fox is sinking. If you should view him under such circumstances creeping along with drooping brush beneath a hedgerow, you will rightly, however, holloa "Tally ho!" or, better, raise your hat to acquaint the huntsman of the fact, and if he then thinks it advisable to "lift" his hounds to the spot he will do so; but it is not for you, by continuing to holloa, to raise their heads, which, I may add, would be a much easier matter than his subsequent task of getting them down again. Overeager and excitable sportsmen have, by adopting such a noisy course, not unfrequently denied hounds the blood they would otherwise have very shortly obtained.

Lastly, recollect that the position of a master of hounds is a most trying one; he is the commanding officer of the hunting field, and as such his orders should be as promptly obeyed as if he occupied a similar position on the Barrack square. His is indeed at times a trying post to fill, and when you consider the undisciplined throng, many of whom are ignorant of the very rudiments of sport, which daily come under his supervision, to many of whom 
one crop is as another, and hounds merely objects to ride at! When you consider these things, and also his keen anxiety to provide you with sport, I am convinced that you, and each one of us who have the interests of fox hunting at heart, will endeavour to let no action of ours make the arduous task a more difficult one than it necessarily must be.

By acting upon the advice I have given you, I venture to think you will not only set an example worthy of imitation, but personally do much to ensure the prosperity of your hunt, as well as towards promoting the good sport it may be destined to afford its followers.

\section{TWICE SOLD.}

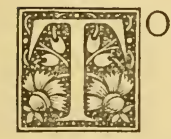

OM SCORER was a smart fellow, a good judge of a horse, fine resolute rider, always open to deal, and with morals, I must reluctantly add, of the most elastic and accommodating order.

It so happened that upon a certain Saturday, not a few seasons ago now, that he completely pounded the whole of the Bankshire Bruisers over a great gaping brook-a brook which he, with as much good fortune 
as judgment, had got over with a considerable scramble, in the only jumpable place thereabouts.

His position was then enviable enough, for the breaking of the bank where he landed effectually barred the possibility of his example being followed, and so he galloped away over the sky-line hands down and alone save for the racing pack, which were silently but surely gaining ground on as stout and straightnecked a vulpine rover as ever broke covert.

Twenty-five minutes to oneself with a crack pack of hounds, in the very cream of their country, does not fall during a lifetime to the lot of many of us, and Tom and his little hog-maned grey very richly deserved the general congratulations vouchsafed them upon the arrival of the remainder of the field at Bleakdown Ash, where the staunch old fox availed himself of an open earth, after running, in all, for forty-seven minutes, and as straight as you could rule a line upon your ordnance map.

But before even the Squire and Dick (his most indefatigable huntsman) had appeared on the scene, the gallant little grey's flanks had resumed their wonted action; nor were his nostrils any longer quivering and distended. It was a good performance, and the popular master did not commit a very grave error of judgment in quietly purchasing the little horse there and then for I20 guineas, some 70 
more, nevertheless, than Tom had himself secured him for scarcely a month earlier.

Hounds were a good way from their kennels, and clean out of their own country, so, as the nearest covert they could draw was some seven miles distant, "Home" was the order, and thither, in this direction and in that, the little group of horsemen dispersed; one alone diverging from his direct road to accompany our hero, whose honesty (if not his wits !) was too severely taxed when his companion -who was no other than the wealthy Mr. Vane, of the Stock Exchange-offered him, after a good deal of fencing the subject on Tom's part, for which such little conscience as he had was, perhaps, responsible, a cool 200 for his mount. The fact that the grey had, before his arrival on the scene, become the property of the M.F.H. being, of course, unknown to Mr. Vane.

Tom could not resist so tempting a second offer, so accepted it, like the sad rogue I fear he was, promising, as in the Squire's case, to send the horse over, without fail, on Monday. And then, at the next cross roads, he bid Mr. Vane good day, with as long a face as that of a priest performing absolution. How Mr. Scorer then pushed briskly on home, how he went up to London dinnerless by the next train, and how, when there, he set the wires in motion in 
divers different directions, to secure such assistance in his need as sundry kindred spirits could afford him, I need not dwell on, as it will, doubtless, suffice for me to say that the purport of the said messages was somewhat to this effect:-

"Do-you-know-dappled-grey-thirteen-stonehorse-fifteen-three-six-years-must-have--such -Monday-liberal-commission-answer-paid."

How he traversed from this stable to that, and from one dealer's yard to another, and how he in vain scanned the occupants of Messrs. Tattersalls' stables the following day, is, too, a fact, though one as wholly disappointing to our friend as the search was itself fruitless. It is also true that after railing down to Reading later in the day, with a like result, he actually was almost despairing of success'altogether, and beginning to wonder instead how he should ever get out of his uncommonly awkward dilemma. But "all comes to those who wait," and a little brickdust colored envelope, containing a telegram from Cheltenham, dispelled Tom's fears, upon his return, somewhat late in the evening, to his London hostelry, as thoroughly as if success was already assured. To consult the A.B.C., pack up, and pay his bill, was not a long matter, and in less than an hour from his return he was again under steam, whizzing along through the darkness by the night, or rather morning 
mail, en route for the sporting centre alluded to.

He was not long, when that was reached, in knocking up the sender of his message, and as time was very precious, and, indeed, money in this case, they mutually lost none, but hastened as soon as the grey morn broke to a certain repository to inspect the stud of an enterprising Irishman, which were standing there at the time. The helpers were not a little astonished at having such unusually early visitors, but a few shillings soon paved the way to their civility, and on a certain grey having been stripped and pronounced "about the ticket," one of them very cheerfully scuttled off at best pace to arouse its owner, who was peacefully sleeping off the effects of the previous night's whiskey at an adjacent and third-rate hostelry. But Mr. O'Flaperty was nothing if not a business man, so he did not, when he had ascertained the reason of his early summons, sivear more horribly than the ordinary run of mortals would have done under like circumstances, but quickly proceeded, after a hasty toilet-for he was not amphibious-to join the gentlemen whom we have so unceremoniously left in consultation at the stables.

After but little delay, the horse in question was then bought and sold, and Tom, minus fifty-five guineas and some suitable "bonus" to his co-operator, was, a few hours later on, bowling along with his new charge 
in a horse-box, duly bound for his native Shire once more. On his arrival at Brassington, the loose hair strewn about the bottom of the box plainly testified to Tom's industry during the journey, and his sore finger-ends still more feelingly endorsed the fact. For no sooner, in truth, had the train left Cheltenham, than Mr. Scorer did, with considerable agility, climb through the little door communicating between his horse's compartment and that he himself occupied, and there and then proceeded to convert, as far as was possible, with the aid of resin and scissors, that rough Irishman's legs into four bearing a closer resemblance to those of the game little horse at home. Later, when that much-desired haven was safely reached, his mane was neatly correspondingly hoged, and after a further and more careful "titivation," he really was a very fair match indeed for the bold little fellow in the adjoining stall

The day was waning when the latter reached the Squire's stables, and the Irishman, "his double," those of Mr. Vane; and it was a matter of no small relief to Mr. Thomas Scorer, when, very considerably later on, the two lads whom he had despatched returned safely with the respective "cheques" of the gentlemen above-named for the amounts bargained for.

So far as I know the Stock-broker never really 


\section{Tluice まold.}

discovered the fraud; but, as a matter of fact, we have seen very little of him in our parts since, for the day after his new grey had been delivered to him, he wagered a cool hundred with a friend that he had a horse in his stable which he would ride over fifteen feet of open water in cold blood, and the result was not eminently satisfactory to his vanity, for it is a matter of history now how he never succeeded even in getting the raw Irishman within fifteen feet of the water, as well as that he left his hunting quarters at Rosehampton the same eventful evening never to return. How the assembled crowd did roar at his futile endeavours to negotiate the leap-pretty women and gallant men alike apparently enjoying his discomfiture very considerably.

He was no loss to the neighbourhood though, in fact rather the contrary, as he never subscribed a shilling to hounds, was rude and over-bearing in manner, and only profuse in his expenditure upon himself.

Under the circumstances, therefore, although the means were very far from being justified by the not undesirable end, I fear that most of us looked a little more leniently upon Mr. Scorer's sharp practice than a proper sense of right should have dictated, when one by one the facts of the case eked out later on as I have endeavoured to record them here. 


\section{HILLMORTON.}

10. ITH gladdening cry o'er the low rail they're bounding,

Each one would be first as the covert they quit ;

By courtesy "gorse," though the fact is astounding, 'Midst withey and blackthorn I ne'er saw a bit.

They sail o'er the meadows-the brook intervening,

Twice six feet of water, or may be thirteen ;

To write but of fact, I may add, is my meaning,

Eighteen would on paper look better, I ween.

Yes, onward the black, tan and white fairly races,

Out-pacing the horses - its quarry ahead

But just to the left of the scene of the 'chases-

The best hunter's course in the world, I've heard said.

He enters a belt, but abandons its shelter,

Turns short to the right, where the winning-post stood,

And crosses the lane where e'en now, helter skelter,

McAdam's contingent his point's nigh made good.

Lead on, little rover, past Lilbourne to Crick, where

I see you are headed; so turning again

Re-cross the street road-to run down it a trick were

Your race like when sinking with pace spent in vain. 


\section{TXalking a ł̧uppy.}

The brave fortune favours; and surely that holloa

Has rais'd the hounds' heads-though well meant,

I daresay,

But rustics will yell-and a fresh fox hounds follow, And thus our red rover is spar'd for to-day.

The cream of the thing, though but short, is now over;

Too short-but delightful as country and speed Could now make it - a ring nearly back to the covert ;

A brief twenty minutes we're fully agreed.

Hounds only drag'd on to the earths by the Station Of Crick, or of Kilsby, or both, I know not; But men who were "there" say, without hesitation,

A faster score minutes ne'er fell to their lot.

\section{WALKING A PUPPY.}

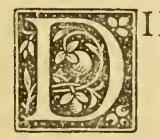

ID you ever walk a puppy? No! Well then, as you certainly ought to assist your energetic M.F.H. by doing so, and doubtless purpose adopting such a course when the kennel cart next goes its rounds with the juveniles, you will, perhaps, permit me, who have walked many, to give you a few hints as to their diet and management, as well as to make some remarks upon their eccentricities. 
In the first place, they must have no restraint whatever placed upon their liberty-and this is a sine quâ non-for you had far better not volunteer to take a youngster at all if you purpose keeping him in confinement, freedom being essential to the health and growth of the puppy, as to the subsequent usefulness of the hound.

Your cook may, and, indeed, probably will not look upon his periodical visits to the kitchen or larder with favour, and, when encountered by her there, it is more than probable that he may meet some slight rebuff at the instance of a mop, broom, or even fryingpan; but, if such should prove the case, he will only more or less hastily retire, fully mindful of the fact that it is no use crying out after you are hurt, and certainly return later on, when fortune is more propitious, for the remainder of that cold pheasant or ham.

The gardener may not look upon him as the most satisfactory of his assistants, but, nevertheless, Master Pillager will, from time to time, re-adjust such of the former's work as he may not approve of, and in nine cases out of ten will select the asparagus, or some equally cherished bed, for his larder.

If, moreover, he has floral tastes, which is highly probable, he will not unfrequently cull the choicest 
of the flowers, or extract them by the roots, to adorn the lawn in front of your windows by scattering them tastefully upon it.

He will, probably, readily accompany your grooms when at exercise, and be the best of friends with all the cur dogs you possess; for let the latter be never so surlily disposed towards him, he will either roll them over with his great fat paw, in perfect good humour, or quietly lick their growling visages "till the clouds roll by."

He will probably run about amongst your sheep, or those of your neighbours-parade them, so to speak, but seldom really run, or in any degree injure them; and to see him romp with, charge and retire, only to charge again, your cow stock, which he has brought to bay, is a sight as amusing to you as it is devoid of harm to them.

Whilst he is in your possession, it is possible that the hares within a widish radius may not retain their respective forms for long together; that the rabbits will take exercise of a more active-kind than is their wont; and that even the usually unaspiring French partridge (if such a pest exists) will acquire, under Pillager's tuition, the desirable art of getting more quickly under wing.

It is a treat to hear his deep baying cry as he recognises and runs to meet you, as it is laughable to 
see the helpless way in which he "flops" himself upon his side at your feet by way of greeting, and in anticipation of some caress.

Notwithstanding, however, their numerous peculiarities, the disgrace they are from time to time getting into in one quarter or another, and the mischief (I regret that I can use no milder term) they occasionally do, I should personally deem the absence of a foxhound puppy from my home as little short of a calamity.

In conclusion, I must add, for the information of such as have not hitherto enjoyed the privilege of walking one, what I, from experience, have found to be the diet on which they usually thrive best. It embraces the following, namely: Biscuits, stable rubbers, the food mixed and designed for your pigs, the spokes of your carriage wheels, any cold meat, game, or puddings which may be obtainable, wash leathers, milk, clothes pegs, brushes, fowls or ducks eggs (the farther advanced towards hatching the better), gloves, bandages, and all other such light and digestible delicacies as fancy and opportunity may dictate, and when I add that I have invariably sent my young hounds back to kennel in condition satisfactory to the huntsman, it is, I think, sufficient guarantee that I am entitled to speak with some authority upon the subject. 
As I write, I perceive that my present puppy is carefully engaged in barking an ornamental flower block on the lawn, but I think as he has, I am informed, previously made a light breakfast off a pair of knee-caps and a cold chicken, that he has, perhaps, had enough of so indigestible a substance, and if you will excuse me I will now go and tell him so, and at the same time bring my chapter to a conclusion.

\section{THE BEST SPORT ON EARTH.}

ITH horses and hounds full of muscle and
breeding,
A morning like this to throw off at the gorse; A ștraight-going fox, and a scent we're but needing, To test the true merits of man, hound, and horse.

For forty fast minutes I trust we may scamper

O'er turf, plough, and meadow ere reynard's roll'd o'er ;

The brook in the valley may give some a damper, And ox-baulking doubles may spill many more.

No matter! good nerves will stand many a downer, We'll make up lost ground by sheer courage and pluck ;

For he who's delay'd by "imperial crowner"

Must win back his place, if he can, by good luck. 
The funkers and craners may skirt, as they ever Have done and will do till the end of all things; But forty good minutes such men would see never,

Tothem 'tis more sport when a fox runs short rings.

But here's to the men who to ride it are praying;

Those quick forty minutes they crave for with me ;

Hark! holloa! a cap off, no time for delaying Is this, if this glorious run we would see.

Sit down in your saddles, lay hold of your horses, And send them along, as you well know the way; The end of this fox, from the best of all gorses,

We otherwise never shall see, Sirs, to-day!

Here's to the survivors, the good men, and plucky, Who've ridden the line from the start to the end; Here's better luck, too, to such sportsmen unlucky Who lost their good place through assisting a friend!

Each hunt has good men of its own; nerve and daring Are still far from scarce in the land of our birth; May jealousy never with courage be sharing Their breasts; "Here's success to the best sport on earth!" 


\section{ON SELLING HORSES.}

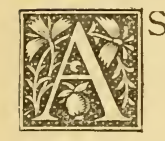

the charitable usually give away that which they do not themselves want, so the owner of horses usually disposes at auction of those which he does not like, or which are, from one cause or another, unsuitable to his requirementsthe worn-out, the vicious, or the unsound, the horses which will kick a threepenny bit before them, and on which your neck would be imperilled did they encounter a sixpence or any substance of similar thickness in their path.

But to this, as to all rules, there are exceptions, as in the instance of your humble servant and others, who sell out for no other reason than to help to pay their corn bills, and who, by buying and making young horses, hope, often vainly, with ordinarily good fortune to get more sport out of their limited incomes than their scantily-filled pockets would otherwise permit of their doing.

But I have taken pen in hand to write for the benefit of the generality of sellers by auction, and purpose, from experience reaped here and there, as well as from imagination, to offer some hints as to "descriptions" which may be given, sufficiently misleading to deceive the unvary purchaser, and yet 
not sufficiently untruthful to imperil wholly the veracity of the would-be vender.

If, my friend, you have an utterly worn-out horse, which, were you either an angel or a Crœsus, you would conscientiously describe as such-or, better, commit to the boiler-for catalogue purposes the following may, perhaps, be a suitable definition: "Climax," a chestnut gelding, aged, "a finished hunter."

The second of the string you wish to dispose of is possibly a rank refuser, which no earthly power can induce to negotiate any obstacle which chance may throw in her way. We will style that excellent and discreet mare "Prudence," and write her down, without prevarication, as "a careful fencer."

If your third horse is a runaway, "Retreat" will be an appropriate name (it also savours somewhat of peaceful security), and that brown gelding may be pronounced as "free in saddle and harness, fast, and will go straight anywhere," and, further, to inspire confidence, you may add, "A snaffle-bridle horse," as, in truth, any horse is, provided that the rider is fool big enough to risk his neck on the brute's back in such unsuitable tackle!

The horse that, whilst in your possession, has, from his vicious propensities in the field, established an unenviable notoriety, you may justly describe as "a 
horse well known (omit adding "too") with the Featherstern Hounds," several of which he has probably drafted; and the crib-biter you are sick to death of, may, after his other excellencies have been enlarged on, be quoted as "particularly good at timber, and never shy of his manger."

The horse which has endangered your neck by grazing and chancing every fence exceeding two feet in height, you may, I think, feelingly write down as "a fine fencer," although it is unnecessary for the public weal to state that he systematically does all his fences considerably too finely for the nerves of yourself or any ordinarily constituted man.

The buck-jumper which has so often laid your august self and your dependents in the dust or mire, needs no prevarication in delineating his character, for you are certainly warranted in terming him "Evictment," a bay gelding, etc., " a big and natural jumper ;" or, should you desire at greater length to enlarge upon that acrobatic animal's capabilities, "a light-hearted horse, jumps like a buck, and has been regularly hunted," might meet his case. For has he not been regularly hunted by each of you in turn, as, having regained your fect and shaken the sparks from your eyes, you started off in hot pursuit of that fleeting steed!

The horse which, from cataract, or what not, has 
totally lost the use of one of his optics, you may chronicle thus: "Sunfish," a grey gelding, etc., "never takes his eyes off his fences."

The roan that persistently jibs along the road, and which no amount of pressure will induce, before his own good time, to proceed, is, moreover, surely "a good stayer," and the little whistling black, who tunes away all the while, may be adequately described as "Blackbird," a black gelding, six years, "goes like a bird in any country."

The liver-chestnut, who is, alas, subject to staggers, is necessarily, if naught else, a "fit" horse for any purpose, and the horse whose gait is crippled by those two deep-seated corns, in addition to other embellishments, may be entered as "never off his corn."

That confirmed roarer, old "Steam-engine," you may characterise as a horse "whose performances speak for themselves," and the soft yellow bay, who can't struggle through dirt shoe deep, is, if good for anything, "a horse for which no day is too hard."

The old white "Centipede," with the ricked back, you may write down as " a straightforward horse," for he is that or nothing, as you well know he can't go backwards. Hence "an improving horse" would meet his case equally well.

"Banjo," that shambling and much knocked about 
slave, with the bunged-up legs, you can dot down as measuring nine inches or what not below the knee, and the splinty and spavined black-brown as a horse with great bone and substance.

The horse that is continually off his feed and wears comparatively threadbare is (like the chancey fencer) entitled indisputably to be styled "a fine performer in any country," and the brute that eats his bedding, and which it is impossible to condition, is, or at all events ought to be, "a stout horse."

The lazy beast, in which you have to bury your spurs even to get to covert, has certainly "lots of metal," and may honestly be so inserted, while the quad you bought out of the bathing machine for general purposes, when giving the family a treat at Margate, is undeniably "good at water."

The ill-tempered brute with one side to his mouth, who, "whither you will goeth not, and whither you would not goes," is, I think, "capable of going anywhere," and the old draft Artilleryman you bought to do odd jobs on the farm, is indisputably "a broken charger" in the fullest sense of the word, and may, as well as not, fill up a chink in the valuable stud you are about to offer the public.

I need hardly add that that dangerous and confirmed rearer-the white-socked chestnut-may be fittingly described as "Justice" (on account of his 
uprightness), "an upstanding young horse, with high action" - the cream color with the stringhalt as "an exceptional goer," and the gammy-legged dun as "a good all-round horse, with great substance." Whereas "The Priest," that hog-maned cob who is so continually on his knees, is surely an animal "you can't pick up every day," for have you not discovered such to your sorrow?

With these few hints I will bring my remarks on horse selling to a conclusion, hoping that thereby I may have done the buyers, if not the sellers, at auction a good turn.

\section{A GOOD RUN, AND A GOOD FINISH:}

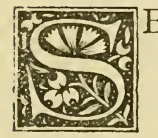

EDGELEY ALDERS is, as most hunting men know, or, as all hunting men in the more favored Shires are at least aware, a little covert of some five acres, which may be described roughly as situated fully three miles from anywhere, and in the heart of as beautiful a tract of feeding and meadow land as the eye could rest upon in any of the three Kingdoms. It is a sure find, and the fixture, from which it is usually requisitioned "The Fox and Hounds," is the meet par 


\section{A Bood Liun, and a bood Jfinish.}

excellence of the Driveandash-a pack which has few superiors, if any; and when they are so advertised to meet it is, therefore, not surprising that great should be the influx from all sides of distinguished and hard-riding strangers. "The Fox and Hounds" is as unostentatious a little wayside inn as you would be likely to meet with in a day's travels; but on these occasions I question if either mine host or hostess, or indeed either of their fair and dimpled daughters, would exchange his or her individual lot for that of even Royalty itself. The ostler, too, has indeed a high time of it ; for a meet there is a gala day to him, and his smiling countenance plainly testifies that his perquisites are in amount as satisfactory to himself as they are incalculable by the writer. How justly proud, too, is the worthy landlord, Mr. Potts, of the puppy he is now walking, and how pleased are the inmates of the old inn to find that Rosamond and Trimbush, who, too, passed their puppyhood there, have not forgotten their former home and friends. It is of no use for Ned and Will, the whips, to "rate" them, for trot down the sanded passage they will to receive a biscuit and caress from the old landlady, let the consequences be what they may. They are not doomed to be serious ones, however, and, having rejoined their companions, it is amusing enough to watch the enquiring glances and busy sterns of the 
latter, expressing as plainly as if in words their desire to learn full particulars of what has taken place during their temporary absence.

But the last stroke of eleven has sounded, and the Master, who is now in the saddle, has given Dick the welcome word "Alders," and amidst a general curveting of steeds a start is made thither-horsemen drawing on to the spongy strip of grass which borders the roadside to let the spotted beauties pass, and in a very few minutes the little hostelry, which was so recently surrounded by such a gaily attired and distinguished company, is again as deserted as is its wont, save for the presence of some few grooms in charge of hacks or carriages, and the usual group of village idlers.

It was our first visit to the covert this season, and the slushy, rushy bridle-way, fenced at first on either side, was nearly impassable to the leaders, owing to the over-hanging hazel boughs and entangled clusters of woodbine or convolvuli that they had to breast through, whilst the so-called road beneath them in many places more closely resembled a rivulet, except that its foundations were very far less sound.

It was all over a hunting morning, and upon reaching the covert hounds eagerly dashed through or over its confines after the welcome signal had been given, and one long and warning blast sounded 
on Dick's horn, to duly acquaint its occupants with the nature of the situation. Our hopes were not destined to be long kept in suspense, for hark! a whimper, followed by a steadier and more confident note, and endorsed by yet another and another, proclaims that our confidence in the covert has assuredly not been misplaced. These are thrilling moments, and in almost less time than I have taken to write the words, that there is a scent, and a good one, is apparent, for that swelling chorus is evidence more reliable than the duly attested oaths of all the Bishops in Christendom.

But we have no time to congratulate ourselves on the fact, and hardly to peep at our watches, ere "Forrard away!" rings clearly out from the farther side of the covert, setting instantly some one hundred and fifty horsemen in as rapid motion as the paces of their respective steeds will admit of. It is to some, and ought to be to all, a moment of the supremest bliss; but yet methinks that the pulses of a few hardly beat in harmony with the more regular palpitations of the dauntless heart their waistcoats should encase; but the dreaded Filter-a twisting, treacherous stream for which our fox is pointing-has, before to-day, been responsible for more heart-beating than the most fickleBelle, and has caused, if not uttered, quite as many refusals. 
How the hounds do race; the scent seems really to be breast high, as, dropping their sterns, they show us, and show us plainly, that those must ride, and ride straight too, who would live with them to-day.

How, too, each fence that is encountered or declined thins out the ranks of the hurrying horsemen in their wake, the van being soon left in the undisputed possession of some score only, who skim over the wattled fences as they come, in a style creditable alike to men and horses.

The obstacles take some doing hereabouts, and we are indebted greatly to our good pilot on the grey for carrying away the trappy ox-rail beyond that awkward double, and are most of us not too proud to follow in his wake, like sheep, in single file. But as this course no more surely increases the lead of the leaders than it decreases the possibility of those in rear catching them, it is no wonder that but four of us only are absolutely with hounds as they dip into the sluggish waters of the meandering Filter. It is a good fourteen feet here, but no sooner has the last hound shaken its dripping muddy water from her spotted coat, than we four land high and dry, without even a peck, to their right and left, and sail on with feelings considerably more enviable, I fancy, than are those of the advancing cavalcade approaching it in rear. 
Of course Dick was one of us--for where his hounds are no less surely is he-but as a splash causes us to cast a glance back, it is evident that his first whip will not directly be in a position to assist him, should he need it; but we must leave him to get out as he may, and can rest fully assured that many will prefer stopping to render him assistance than to risking a similar fate themselves. What a halt that disaster has caused-horses refusing, and riders skirting off in all directions; indeed, but one other, as far as we can see ere we sink the hill beyond, gets clean over it, and he far too hopelessly in rear to catch us again if the pace but continues as at present.

We had come "a regular buster" for some four miles or so as the crow flies, but a trifle more as hounds ran, ere Ferndale, a woodland of some three hundred acres, loomed in sight, and on reaching its outskirts the too-eager pack flashed over its yielding boundary fence into that vulpine stronghold itself, as if satisfied that no hard-pressed fox would discard the shelter afforded by such a jungle.

It is, however, otherwise to-day, and Dick, having given hounds a few seconds time, in which their silence was to him sufficient acknowledgment of their mistake, recalls them, with one sharp note on his horn, to the boggy headland they had so 
recently quitted, and trotting his horse slowly down the wood side soon has his own opinion of master pugs probable movements endorsed by busy little Beeswing, whose word is a great deal more reliable than the bond of many very estimable citizens.

"Forrard," therefore, is yet again the order, but the pause, though slight, was welcome; the more so as some fifty yards lower they wheel through an open bridle-gate into the covert, and simply race along the sodden, boggy length of its main riding, gaining on our struggling horses every yard they go. What a game fox it is! for discarding all shelter, he quits it by the gate at its opposite extremity, and when we four turn our backs upon it the hounds have made such good use of their time as to have placed already the willow-fringed bottom in the vale between us and themselves.

We soon, however, get to them again, for the pace, although still good, is not as good as it was in the glorious preceding eighteen minutes ere the wood was reached, and the country we are now entering upon is less stiffly enclosed, as it had need to be, although the enclosures are distressingly smaller, and such being the case, the jumping, through requiring less effort, is necessarily more frequent.

We had been running in all some thirty-eight minutes, when a second check occurred below the 
old windmill at Cattleby-a check which might, however, have been very advantageously longer (as, too, might that yelping shepherd dog have been hung)-for our horses have latterly hung out palpable symptoms of distress, fencing recently in a manner so short and slovenly as to remind us very forcibly that we must not trespass on their highly-taxed courage for much longer.

The huntsman, on the best of timber jumpers, was down over that paltry stile to my right, as I with difficulty induced my game little black to scramble, when relieved of my weight, out of a deep ditch into which she had subsided, and our now only companion had kissed his maternal parent no less than thrice. On another occasion of so doing he, indeed, seemed literally to be suspended in that black bullfinch, but after a momentary pause rider and horse, without an actual dissolution of partnership, scrambled to the other and better side, and Dick and I were only too glad to avail ourselves of the hole they made, for "leps" had for some time past been things not to be trifled with. No, indeed! and so had the rider of the raking chestnut discovered but shortly before, when four of us jumped in, and but three out of that rutty lane.

We had just time to note that the horse who up till then had gone so well will have no more, but 
have enough to do to take care of ourselves and keep hounds in sight, so must leave him, poor fellow, with his horse's extended feet planted firmly in the bottom of the hedge, as, with dilated nostrils and quivering tail, his body literally rocks in response to his hard and quickened breathing.

You may try to ride him over, or to lead him, but your wisest course is to get him to the nearest stable, and recruit his shattered energies as best you can; but we who have still a canter left must leave you to your own troubles and meditations, and I think, Sir, that you must now regret the liberties you took with him during those rapturous minutes which proved to be but the preface to this fine run.

But hark! as we are hunting on more slowly again, from yonder hill comes a holloa, and a billycock waved by a friendly ploughman certifies to its correctness. The intelligence is, moreover, welcome, for the short turns our fox has been latterly making have caused even Dick to doubt ever so little as to how our glorious run may terminate. But now it is another matter, and lifting them as quickly to the spot as his good grey can now bustle along, hounds quickly pick up the scent again, and with gladdening cry commence to run as keenly as at firstindeed, more so, if it were possible-but the pace cannot, we know, continue now for long, and in a 
very few seconds more we see a draggled, panting form, with arched back and drooping brush, stealing along, and but very slowly, beside the straggling boundary fence below us-not surely the same sleek, daring rascal who whisked his brush defiantly in Ned's face this morning, as he bounded from the Alders. But yes! it is no other, and thither, staunch fox though he was, he is doomed never to return. "Tally ho! ellu here! tally ho!" and in response to Dick's cheer the little ladies raise their heads, and catching sight of their foe put an end to his sufferings in less time by far than it has taken me to allude to them, and thus did Whoo hoop bring to an end a veritable clinker from Sedgeley Alders; time, one hour and five minutes-only two very slight checks - and the distance traversed considerably over a dozen miles, as from the covert to Hopeby Park, outside which they killed him, it measured nearly that distance as the crow flies.

The first whip, now nearly dry again, was the next to canter up, and others followed at longer or shorter intervals, until some thirty horsemen in all at length appeared upon the scene ; but three of them, Dick, Charley Sitwell, and I, alone saw the run throughout, and naught but mask, brush, and pads remained of our pilot even when Ned himself reached the end of the chapter in somewhat sorry plight. 
I could not, I saw, get my good black mare home that night, so readily accepted the invitation of the hospitable owner to put her up at The Manor House stables, which, fortunately, were handy, and sufficiently roomy to afford similar accommodation to some half-dozen others, for if they had not ridden the line, the majority had ridden considerably more than the distance, as the appearance of many of the horses very amply testified. I am glad to say that my own good mare was very shortly fully herself again, and not a whit the worse a week later on for carrying me so gamely and so creditably that day.

Alas! it took place some years ago now, and as I write all that remains to me of that prized and generous animal is one silver-mounted hoof, which, with the brush hanging above it, are two as treasured relics of the past as any I possess.

\section{RIDING AT FENCES.}

\section{TIMBER.}

T timber sit steady, and keep his head
straight,
Take a pull at his bridle a few yards away; On either's misjudgment, remember, the fate Of both will depend-of yourself and the grey. 



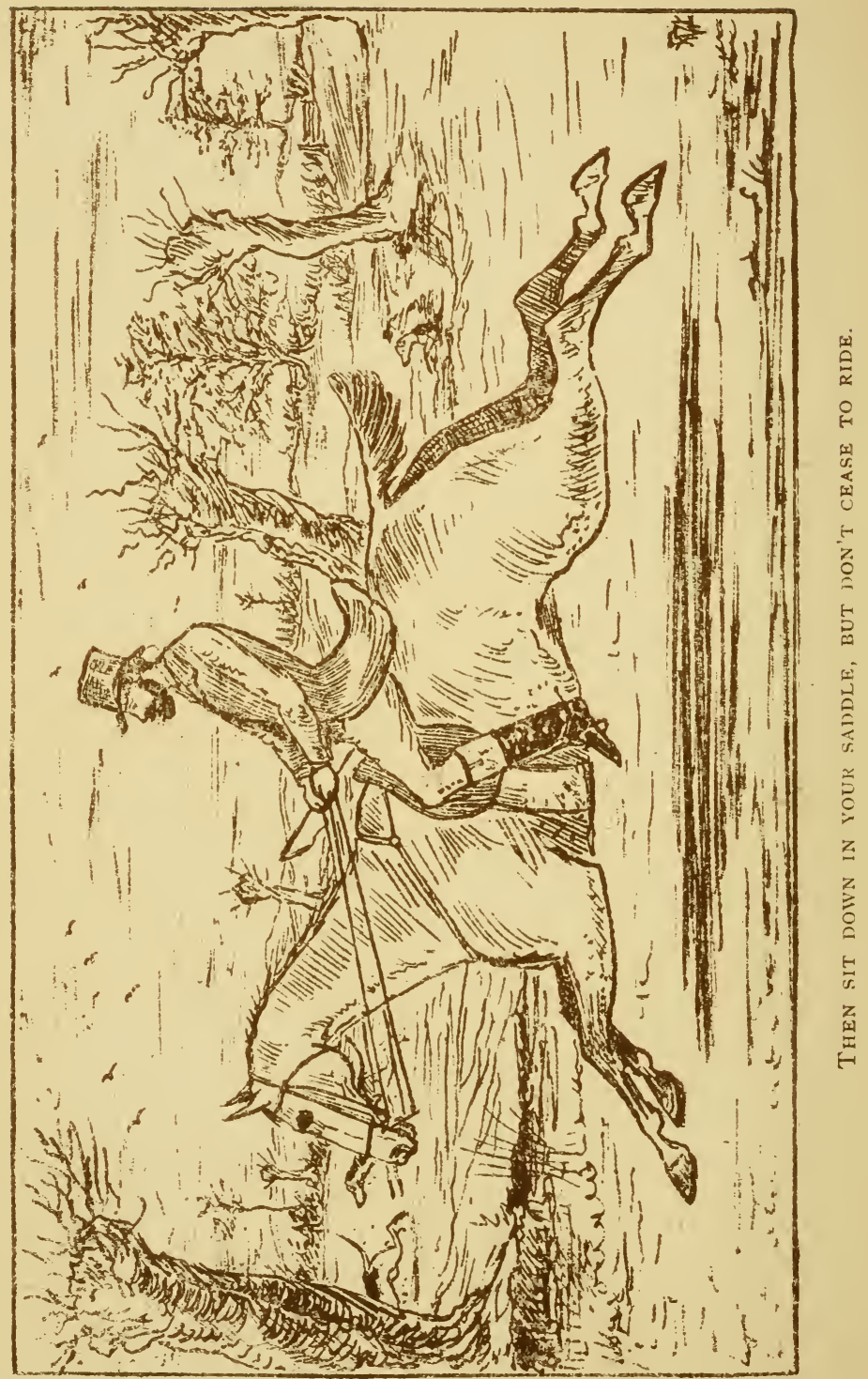


If you feel your horse, as he shortens his strides For the effort, has got his "steps out," as folks say,

Why then, if you have it, that instinct which guides, Use quickly, and check him, though slightly I pray.

An easy hand canters for timber the speed,

And if only you'll keep your head cool, I'll go bail, What brains are possess'd will be us'd by your steed,

Who'll seldom encounter an uppermost rail.

\section{A T E R.}

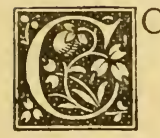

OME now, harden your hearts, there's a brook in the vale!

But two fields ahead, and no bridge for a mile ;

It's a bumper, and if you would over it sail

I will tell you the way, if you'll hearken awhile.

When within forty yards of the brink put on steam,

And ride like a man with his heart t'other side; Send him "into his bridle," and when near the stream

Then sit down in your saddle, but don't cease to ride. 
When you feel that refusal's impossible quite, And he is about to take off, then give rein; And on feeling him land, high and dry, safe and right,

Just re-tighten your hold on the bridle again.

Pray remember, 'tis better to jump yards too far, Than to "lep" one inch short at a treach'rous brook;

Though a ducking we all know's a nastiesh jar, Yet "the less we shall like it the longer we look."

So just harden your hearts as the willows draw nigh, And get the first try just as far as you can; And the odds are that then you will land high and dry, And if not-should you fall-you can rise again, man!

For 'tis better to rise wringing wet, bruis'd and sore,

Remount and sail on with the hurrying pack, Than by funking and craning to see it no more, And join the battalions which English pluck lack.

Thuugh a young horse may skate, and an old one may stick,

Rely on my word, I am right when I state, If with courage and will you ride each at it quick, You but seldom will meet with a watery fate. 


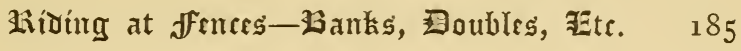

BANKS, DOUBLES, ETc.

25. OU can't go too slow at a blind place or double,

The faster you ride the more risk you will run ;

Your horse has got wits, and he'll steer clear of trouble,

For falling to him-as to you-is no fun.

Although banks and such places will often bring grief, And grief must befall any man who rides straight In pursuit of what Jorrocks has term'd the "world's thief,"

Its sum will depend very much on "the rate."

Hence 'tis better nine times out of ten to go slow

At places like these I have now in my eye;

But keep hold of your horse, just enough, "don't cher know,"

Your own resolution "to go" to imply.

\section{AN OXER.}

N Oxer! O what does that word not imply? Why a rail and a fence, and an "unknown beyond ;"

And the fence we will here take for granted is high And strong, lest the pasture-fed ox should abscond. 
There may be a rail, too, and will be a dyke

On that side we can't see, as we pick the best place; It is not quite the fence which " the multitude "like, You must not go slow, and you yet need not race.

A good swinging gallop's the speed to apply,

Give your horse just one hustle, to show you mean work;

That a fall you will share if he makes a good try,

Nor blame him unless he endeavours to shirk.

You may come a howler, or may do the trick

In as masterly style as it ever was done;

You will find some such fences as these around Crick, Which oftimes have thin'd out "a field" in a run.

But I think I need tell you no more of my mind

Respecting the "leps" which may come in your way ;

My maxims are not unsuccessful, I find,

Though I've tumbled about a good bit in my day.

If you don't want to fall hunt the hare on the downs, Go coursing, or shoot little doves from a trap; Alas! the most careful have got thickest crowns, Though their eyesight is good at discerning a gap. 


\section{SUNSHINE AND SHADOW.}

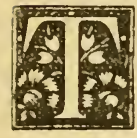

HROUGH sunshine and shadow our pathway is leading

Us steadily onward through Life's little day;

Its ending is Death, and 'tis little use pleading His early arrival, or tardy delay.

To some he is welcome-too welcome to many

Whose lot through their journey has sorrow ful been; Their shadows lay thickly, their sunshine, if any, Was flickering brief, and so seldomly seen.

With love unreturn'd, and with lov'd ones departed,

O little's the wonder if dreary the way

Appears to the mourners left here broken-hearted,

Who sorrowing wait for the close of the day.

Some flowers will raise e'en in shadow their faces,

Whilst others will sunless fade slowly away;

So care on some strong ones will leave little traces,

Whilst crushing the hearts of those weaker than they.

Then do not judge harshly the maim'd or the weary,

Who stumble or fall where you pass safely by;

Their pathway is darker, their sunshine less cheery

Perchance, than the rays which around yourstepslie. 
We cannot exchange with each other our crosses,

The weight of the burden of each none can guess The struggle one makes to prevent further losses, If us'd by another were crown'd with success.

We only our several talents are keeping,

Some many, some less, as His will doth ordain ; O'er other men's faults we have no time for weeping, What seems to us loss may in His sight be gain.

\section{TO E. M. W.}

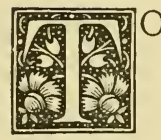

ODDLE along by aid of a chair,

Little babe mine, and you soon will walk;

Chatter, my babe, and you soon will talk.

Reach out your hand, and toddle away

To mother's side; now you're safely clasp'd ;

May life's rough voyage be so made, I pray, And the wish'd for haven reach'd at last.

Stagger you did, but you did not fall;

A hand then saved you, and one will save If, when you can talk, you learn, aye, to call

On Him who our babe's existence gave.

Sleep away, babe, on your mother's breast,

Peacefully sleep, and grow good and strong;

Grow up of small daughters the very best,

Brave to do right, and resist the wrong. 


\section{FACT AND FICTION.}

" OU still may be what you might have been,"

'Tis thus, you tell me, the Poet sings;

And cheery and sweet sounds the song, I ween,

And kind is the note which the tidings brings.

But as long as mind and mem'ry live,

As thought and reason, too, remain,

Can the future relief to bygones give,

And create new hopes unbedim'd by pain?

You've smash'd your vase in a thousand bits;

Pick them up, and unite them; well!

If it does not leak you can see the splits,

The traces of where it in past times fell.

And if it gives you the pleasure still

It gave you once to view and hold, Then trouble and sorrow can never kill,

And with pure young hearts are endow'd the old.

But you may be what you might have been,

Good Sir, alas! and spotless Miss;

But had you erred when your life was green

You'd laugh as you read such twaddle as this. 


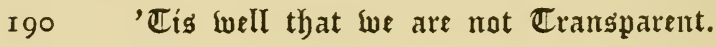

Though pretty the lines your kindly pen

Has worded, and I thank thee much, Still, the bed which is made by reckless men,

If of thorns, for aye must they lie on such.
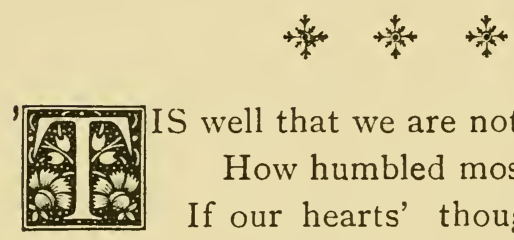

IS well that we are not transparent;

How humbled most of us would feel If our hearts' thoughts were made apparent,

If words were honest wishes real.

If ev'ry glance and thought and action

Were patent to be read by all,

Our pride would undergo contraction,

Our bitter speeches not appal.

Then those beneath our glances quailing,

And fearing now rebuke or sneer,

Might find us bitterly bewailing

Our chances lost for ever here.

But when we see as $\mathrm{He}$ sees, clearly;

When one and all cast off disguise ;

Methinks those rank'd by Him most dearly

Will wipe the shame tears from our eyes. 
狂atiently ミtríbe to vo Liight.

ATIENTLY strive to do right;

Sow if you may not reap ;

Early and late, with your might,

Labour and strive-not weep.

Fearlessly friend greet, or foe, If but your heart be trueTrouble you may have, and woeJoy's yet in store for you.

Glimmering bright, aye, or bleak, Life's but a short, short day; To its close be brave, if weak : Striving as best you may.

Faithfully grasp the strong arm Held out to guide and save; Then-freed from sorrow and harm, Heaven shall be thy grave.

\section{A NEW YEAR'S WISH.}

To G. M. R.

"W 19 make our own happiness," somebodysaid, "And create our sorrows, too ; Bliss on the heels of virtue will tread, And folly will toils renew." 
If so, perhaps needless that I should now pray

That your life be free from ill,

If our fates be as the potter's clay,

To be bent and turn'd at will.

Yet, my wish is this-whether idle or no,

To you may the budding year,

As it scatters others' grief and woe,

Bring only its blessings near.

May each day and week, as they draw to a close,

Bring you naught o'er which to sigh;

Through joy, contentment, peace and repose,

May your future pathway lie.
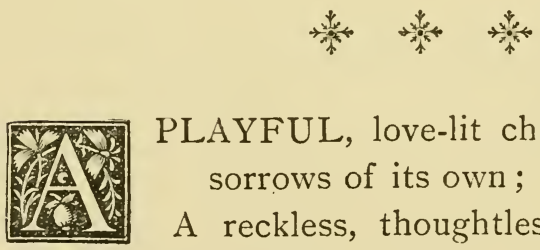

PLAYFUL, love-lit childhood-still with sorrows of its own;

A reckless, thoughtless youthtide-wild oats sown ;

A conscience-stricken manhood-pleasures fleeting as years fall;

A harden'd worldly life, and that is all.

A crush'd and bitter childhood-quite "the good boy" of the school;

A priggish, sunless youthtide-on a stool ; 
A loveless, striving manhood-money-getting, that is all;

A prim and prudish life, without a fall.

\section{Oh, who shall dare to say}

Who life's most cast away ;

The warm, the wilful wanton man, or he

Who sleek and slim outside,

Encas'd in conscious pride,

Has Pharisee-like bent in pray'r the knee?

May $\mathrm{He}$ to each one prove

A God of boundless love;

Of love and pity far beyond our ken.

May saint and sinner, too,

Through Him be born anew,

And win the peace allotted unto men.
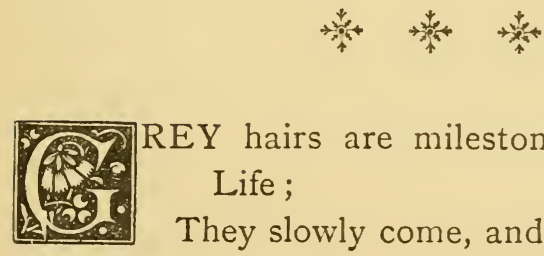

REY hairs are milestones on the road of Life ;

They slowly come, and still we heed them not,

Till, weary of the turmoil, pleasure, strife, We'd rest awhile; finding no strength we've got $\mathrm{N}$ 
To run on farther with the merry throng We'd led till then at pace too good to last; Find that our voice jars in their joyous song, And that our noonday is already past.

"Redeem the wasted hours," the Preacher cries; "Blot out their mem'ry," louder yells Despair; And man, who sought not life, crawls on and dies, Crush'd down as camel by the last (grey) hair.

\section{LOOKING BACK.}

OOKING back! yes, it is more than sad looking back through the misty past,

Dim with the fogs of folly, and worse-bright with pleasures too sweet to last;

Here resolutions good were made-you may note the spot by the sunny ray,

Well-nigh eclips'd by the darker blot, which denotes how soon they, alas! gave way.

Here on Life's map, and there, we trace a moisten'd spot from a heart-felt tear;

Sacred tokens, you each efface some lov'd one's name held, alas! so dear ; 


\section{$\mathfrak{A}$ spríg of Arbor ש̂titx.}

How many friends have faithless prov'd ; to how many friends have we prov'd untrue?

Have broken bonds made us now more wise, or made us more value the trusty few?

Those who help'd us up yonder hill, and gave us a hand to guide us, when

Such as we trusted withdrew the light we thought shone but for us till then.

Roll up the map of our weary way-take a new sheet for the coming year,

As before, alas! both clean and neat, and determine a straighter course to steer.

Then by and bye, if it ever comes, may we not sadly have to say,

That friends are false, and the map is smudg' $d$ where good resolves have given way;

So marr'd and soil'd from the dust and mire of trouble and care, of joy and wrong,

That the few bright spots on Life's stony track make the journey seem more dark and long.

\section{A SPRIG OF ARBOR VITAE.}

SPRIG of Arbor Vitæ, torn

By loving fingers from a tree;

A sprig of Arbor Vitæ, worn

A few short hours by me. 
A sprig of Arbor Vitæ green, By loving fingers pluck'd for me; Much treasur'd emblem of what's been, And what shall ever be.

O sprig of Arbor Vitæ, dead, Though cherish'd still, you soon will be ; But "Friendship shall for aye," she said, "Blossom 'twixt you and me."

O sprig of Arbor Vitæ, when I'm laid with better ones below, And still'd is erring heart and pen, For me one tear will flow.

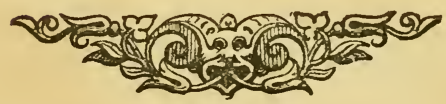





